\title{
Methane emissions from floodplains in the Amazon Basin: challenges in developing a process-based model for global applications
}

\author{
B. Ringeval ${ }^{1,2,3,4,5}$, S. Houweling ${ }^{1,2}$, P. M. van Bodegom ${ }^{3}$, R. Spahni ${ }^{6}$, R. van Beek ${ }^{7}$, F. Joos ${ }^{6}$, and T. Röckmann ${ }^{1}$ \\ ${ }^{1}$ Institute of Marine and Atmospheric research Utrecht (IMAU), Utrecht University, Utrecht, the Netherlands \\ ${ }^{2}$ SRON Netherlands Institute for Space Research, Utrecht, the Netherlands \\ ${ }^{3}$ Department of Systems Ecology, Vrije Universiteit, Amsterdam, the Netherlands \\ ${ }^{4}$ INRA, UMR1391 ISPA, 33140 Villenave d'Ornon, France \\ ${ }^{5}$ Bordeaux Science Agro, UMR1391 ISPA, 33170 Gradignan, France \\ ${ }^{6}$ Climate and Environmental Physics, Physics Institute, and Oeschger Centre for Climate Change Research, University of \\ Bern, Bern, Switzerland \\ ${ }^{7}$ Department of Physical Geography, Utrecht University, Utrecht, the Netherlands \\ Correspondence to: B. Ringeval (bruno.ringeval@bordeaux.inra.fr)
}

Received: 23 September 2013 - Published in Biogeosciences Discuss.: 29 October 2013

Revised: 10 February 2014 - Accepted: 11 February 2014 - Published: 21 March 2014

\begin{abstract}
Tropical wetlands are estimated to represent about $50 \%$ of the natural wetland methane $\left(\mathrm{CH}_{4}\right)$ emissions and explain a large fraction of the observed $\mathrm{CH}_{4}$ variability on timescales ranging from glacial-interglacial cycles to the currently observed year-to-year variability. Despite their importance, however, tropical wetlands are poorly represented in global models aiming to predict global $\mathrm{CH}_{4}$ emissions. This publication documents a first step in the development of a process-based model of $\mathrm{CH}_{4}$ emissions from tropical floodplains for global applications. For this purpose, the LPXBern Dynamic Global Vegetation Model (LPX hereafter) was slightly modified to represent floodplain hydrology, vegetation and associated $\mathrm{CH}_{4}$ emissions. The extent of tropical floodplains was prescribed using output from the spatially explicit hydrology model PCR-GLOBWB. We introduced new plant functional types (PFTs) that explicitly represent floodplain vegetation. The PFT parameterizations were evaluated against available remote-sensing data sets (GLC2000 land cover and MODIS Net Primary Productivity). Simulated $\mathrm{CH}_{4}$ flux densities were evaluated against field observations and regional flux inventories. Simulated $\mathrm{CH}_{4}$ emissions at Amazon Basin scale were compared to model simulations performed in the WETCHIMP intercomparison project. We found that LPX reproduces the average magnitude of ob-
\end{abstract}

served net $\mathrm{CH}_{4}$ flux densities for the Amazon Basin. However, the model does not reproduce the variability between sites or between years within a site. Unfortunately, site information is too limited to attest or disprove some model features. At the Amazon Basin scale, our results underline the large uncertainty in the magnitude of wetland $\mathrm{CH}_{4}$ emissions. Sensitivity analyses gave insights into the main drivers of floodplain $\mathrm{CH}_{4}$ emission and their associated uncertainties. In particular, uncertainties in floodplain extent (i.e., difference between GLC2000 and PCR-GLOBWB output) modulate the simulated emissions by a factor of about 2 . Our best estimates, using PCR-GLOBWB in combination with GLC2000, lead to simulated Amazon-integrated emissions of $44.4 \pm 4.8 \mathrm{Tg} \mathrm{yr}^{-1}$. Additionally, the LPX emissions are highly sensitive to vegetation distribution. Two simulations with the same mean PFT cover, but different spatial distributions of grasslands within the basin, modulated emissions by about $20 \%$. Correcting the LPX-simulated NPP using MODIS reduces the Amazon emissions by $11.3 \%$. Finally, due to an intrinsic limitation of LPX to account for seasonality in floodplain extent, the model failed to reproduce the full dynamics in $\mathrm{CH}_{4}$ emissions but we proposed solutions to this issue. The interannual variability (IAV) of the emissions increases by $90 \%$ if the IAV in floodplain extent is accounted 
for, but still remains lower than in most of the WETCHIMP models. While our model includes more mechanisms specific to tropical floodplains, we were unable to reduce the uncertainty in the magnitude of wetland $\mathrm{CH}_{4}$ emissions of the Amazon Basin. Our results helped identify and prioritize directions towards more accurate estimates of tropical $\mathrm{CH}_{4}$ emissions, and they stress the need for more research to constrain floodplain $\mathrm{CH}_{4}$ emissions and their temporal variability, even before including other fundamental mechanisms such as floating macrophytes or lateral water fluxes.

\section{Introduction}

Methane $\left(\mathrm{CH}_{4}\right)$ is an important atmospheric component because of its contribution to radiative forcing and its role in atmospheric chemistry. Its chemical interactions result in indirect radiative forcings through its impacts on the oxidizing capacity of the atmosphere, and the production of tropospheric ozone and stratospheric water vapor. Wetlands contribute between one-quarter and one-half of global $\mathrm{CH}_{4}$ emissions (Kirschke et al., 2013). However, both the global magnitude and the latitudinal distribution of wetland emissions are poorly known (e.g., Denman et al., 2007). Tropical $\left(30^{\circ} \mathrm{N}-30^{\circ} \mathrm{S}\right)$ wetlands are estimated to represent about $50 \%$ of the natural wetland $\mathrm{CH}_{4}$ emissions. In addition, tropical wetlands also contribute to the variability in atmospheric $\mathrm{CH}_{4}$ concentration at different timescales, ranging from glacial-interglacial cycles (Loulergue et al., 2008; Singarayer et al., 2011, Baumgartner et al., 2012) to the currently observed year-to-year variability (e.g., Bousquet et al., 2006).

To estimate regional to global emissions of $\mathrm{CH}_{4}$, two modeling strategies are commonly applied: the top-down and the bottom-up approach. The top-down approach, also referred to as atmospheric inverse modeling, optimally combines atmospheric observations of $\mathrm{CH}_{4}$, a model of atmospheric chemistry and transport, and a priori information about sources and sinks (e.g., Bergamaschi et al., 2009; Bousquet et al., 2006, Monteil et al., 2011). The bottom-up approach integrates the available information about wetland $\mathrm{CH}_{4}$ emissions at the process level into regional (Bohn et al., 2007) and global terrestrial models (e.g., Riley et al., 2011; Ringeval et al., 2011). The two approaches are complementary, in that they address different spatial scales and are constrained by observations relevant to different parts of the $\mathrm{CH}_{4}$ budget. Top-down estimates provide only limited insight into the underlying biogeochemical processes controlling emissions, particularly over regions where several processes and sources overlap. In contrast, the bottom-up approach incorporates knowledge of small-scale processes, but extrapolation of their local emission estimates to larger scales compatible with the atmospheric signals is uncertain. Top-down and bottom-up approaches are usually not independent since the top-down approach often uses bottom-up emission maps as an a priori estimate (e.g., Spahni et al., 2011). Due to the current limitations of each approach (see e.g., Houweling et al., 2013 about top-down models), the uncertainties after combining them are still large. This applies to both the size of global wetland emissions and their year-to-year variability (Kirschke et al., 2013). Despite these uncertainties, the Amazon watershed has been identified as a key player in the mismatch between top-down and bottom-up estimates (Pison et al., 2013). For instance, the magnitude of the Amazon wetland $\mathrm{CH}_{4}$ emissions increases from 44 to $52 \mathrm{Tg} \mathrm{CH}_{4} \mathrm{yr}^{-1}$ when $\mathrm{CH}_{4}$ retrievals from a remote-sensing instrument (e.g., SCIAMACHY) are implemented as constraints in the inverse modeling system of Bergamaschi et al. (2009).

Both SCIAMACHY $\mathrm{CH}_{4}$ concentrations and airborne measurements (Beck et al., 2012; Miller et al., 2007) showed elevated concentrations over the Amazon, but attributing these high concentrations to specific sources (e.g., wetlands) is not straightforward. In recent years, potentially important - but still-debated new mechanisms of $\mathrm{CH}_{4}$ production under oxic conditions (see e.g., Keppler et al., 2006; Nisbet et al., 2009; Vigano et al., 2008) or anoxic conditions (Covey et al., 2012) have been proposed. Nonetheless, recent isotope analysis showed that the majority of airborne measured $\mathrm{CH}_{4}$ concentration elevations can be attributed to microbial $\mathrm{CH}_{4}$ production (Beck et al., 2012), reducing the number of potential drivers of the observed elevated concentrations. Despite possible alternative sources of $\mathrm{CH}_{4}$ in the Amazon Basin, wetlands thus likely remain the main source of the Amazon $\mathrm{CH}_{4}$ emissions.

Melack et al. (2004) estimated the Amazon-Basinintegrated wetland emissions at $22 \mathrm{Tg} \mathrm{yr}^{-1}$ by combining flux measurements and remotely sensed wetland distributions. However, a large fraction of the spatio-temporal variability in the processes that control the $\mathrm{CH}_{4}$ emissions are not accounted for in this approach, which introduces large uncertainties. The use of land surface models (LSMs) (e.g., Riley et al., 2011) is a promising approach for reducing the uncertainties further. However, the recent WETCHIMP LSM intercomparison experiment (Melton et al., 2013; Wania et al., 2013) shows a large range of estimates for the tropics, indicating that tropical wetlands are poorly represented in these models. This is partly explained by the absence of a dedicated parameterization of tropical wetland ecosystems in the current generation of LSMs, affecting both the estimated wetland extent and $\mathrm{CH}_{4}$ flux densities (i.e., the flux per $\mathrm{m}^{2}$ of wetland). Parameterizations introduced in LSMs to simulate the wetland $\mathrm{CH}_{4}$ flux densities are primarily representative of boreal peatlands (Wania et al., 2010; Zhuang et al., 2004) and do not account for diversity in wetland types (peatlands, swamps, etc.) (Ringeval et al., 2010). Moreover, hydrological models such as the TOPMODEL approach used in some LSMs, for example in the MetOffice climate model (Gedney and Cox, 2003) and ORCHIDEE (Ringeval et al., 2012) to estimate wetland extent, do not allow the simulation of 
floodplains, which is the main habitat associated with wetland in the Amazon watershed (Hess et al., 2003; MiguezMacho and Fan, 2012). Further development of LSMs is urgently needed to account for these omissions, given the importance of tropical wetlands for understanding global $\mathrm{CH}_{4}$.

In the present study, we present the first adaptations of a global process-based model of $\mathrm{CH}_{4}$ emissions to Amazon floodplains specificities. This provides in the first step towards a more realistic model for tropical wetlands. We do this in the framework of the LPX-Bern 1.0 Dynamic Global Vegetation Model (Land surface Processes and eXchanges, Bern version 1.0) (Spahni et al., 2013; Stocker et al., 2013) given its ability to simulate transitions of vegetation types, carbon and water pools between different terrestrial ecosystems. LPX includes a parameterization for the simulation of boreal peatland emissions developed by Wania et al. (2010). Besides, wetland $\mathrm{CH}_{4}$ emissions were estimated in LPX for remotely sensed wetland extents (Prigent et al., 2007) by using simple parameterizations (Spahni et al., 2011, Wania et al., 2013). We adapted the Wania et al. (2010) process-based approach to the case of the Amazon floodplains. To do so, we used the outputs of a hydrological model (PCR-GLOBWB) to prescribe the floodplain extent in the LPX model. The LPX model was extended with a representation of the Amazon floodplain vegetation, focusing on the contributions of trees and grasses to vegetation cover and productivity. The model extended with floodplains and floodplain $\mathrm{CH}_{4}$ is tagged as LPX-Bern version 1.1. The different parameterizations were tested using remote-sensing data (GLC2000, MODIS), in situ flux measurements and results of the WETCHIMP model intercomparison (Melton et al., 2013; Wania et al., 2013). The model was used to estimate the sensitivity of the $\mathrm{CH}_{4}$ emissions from the Amazonian floodplains to different (uncertain) processes. The comparisons with observations and sensitivity tests allowed identifying and prioritizing the challenges faced to obtain more accurate estimates of Amazon $\mathrm{CH}_{4}$ emissions.

Section 2 describes the use of PCR-GLOBWB-simulated floodplains extent, the representation of floodplain vegetation and associated $\mathrm{CH}_{4}$ emissions and the sensitivity analyses. The main results are presented in Sect. 3. Model performance, uncertainties and priorities for future developments are discussed in Sect. 4.

\section{Methods}

\subsection{The base LPX model}

The LPX-Bern 1.0 (hereafter LPX) is a subsequent development of the Lund-Potsdam-Jena (LPJ) dynamic global vegetation model (Sitch et al., 2003), which combines processbased, large-scale representations of land-atmosphere carbon and water exchanges and terrestrial vegetation dynamics in a modular framework. In the following, we briefly present the LPX characteristics relevant to understand the modifications described in Sects. 2.2 to 2.5 to improve estimates of $\mathrm{CH}_{4}$ emissions from the Amazonian basin.

\subsubsection{Vegetation representation}

In LPX, following Wania et al. (2009b), boreal $\left(>45^{\circ} \mathrm{N}\right)$ grid cells are treated either as peatland or as mineral soil depending on the soil carbon content derived from Tarnocai et al. (2009). The computation of water and carbon fluxes differs between these soil types. In particular, peatland soils are vertically separated into the acrotelm and the permanently water-saturated catotelm. This separation is not relevant for floodplains and therefore, floodplains are treated as mineral soils (see Sect. 2.2.1). Plant hydrology is treated following Gerten et al. (2004) with an extension of the number of mineral soil layers to eight following Wania et al. (2009b).

Each mineral grid cell of LPX is split into fractions (hereafter land units, LUs). LUs are reserved for natural vegetation, agriculture (including cropland and pasture), and builtup areas (Strassmann et al., 2008). Peatlands are modeled as a separate LU (Spahni et al., 2013). The natural vegetation LU consists of 10 generic plant functional types (PFTs) that may co-exist. Peatland LUs may contain any of these generic PFTs, complemented by two peatland-specific PFTs introduced by Wania et al. (2009a): flood-tolerant C3 graminoids (sedges) and Sphagnum mosses. Within a given LU, it is assumed that the different PFTs are well mixed. As a result, the PFTs compete locally for resources while different LUs in the same grid cell are assumed to occupy different environments, without competition of PFTs among them. To model Amazon floodplains, we introduced a new LU as well as new flood-tolerant PFTs (see Sects. 2.2 and 2.3).

The fundamental entity simulated in LPX is the average individual of a PFT. Each PFT is characterized by its own set of parameters describing growth, carbon uptake, etc. Photosynthesis and water balance are coupled in a two-step approach. First, LPX calculates the non-water-stressed photosynthesis rate, and then optimizes the canopy conductance based on water-limited transpiration (Sitch et al., 2003). Contrary to most of the commonly used global vegetation models (e.g., see Krinner et al., (2005) for the ORCHIDEE model), there are no PFT-specific parameters for the optimal maximum rubisco-limited potential photosynthetic capacity $\left(v_{\mathrm{cmax}}\right)$ and the potential rate of Ribulose-1,5-bisphosphate (RuBP) regeneration $\left(v_{\text {jmax }}\right)$. This has an effect on our strategy to model flood tolerance for the newly introduced PFTs.

Each woody PFT population is characterized by the population density $(n)$ and a set of variables describing the state of the average individual. For example, the fractional plant coverage (FPC) of a given woody PFT in a LU depends on the foliage-projected cover of the average individual and $n$. For herbaceous PFTs, the big leaf approximation $(n=1)$ is used. Vegetation dynamics are computed at a yearly timescale. Mortality is imposed as a reduction in population density 
at the end of each simulation year. Such reductions can be caused by depressed growth efficiency, heat stress, negative NPP and by exceeded PFT-specific bioclimatic limits. For a realistic simulation of floodplain vegetation cover, tree mortality required specific attention, as will be described in Sect. 2.3.3.

In addition, two rules control the coexistence of grasses vs. trees in a LU of a given grid cell (Sitch et al., 2003), which plays a key role in our study: (i) self-thinning of woody vegetation (i.e., a reduction in the population) if the LU FPC sum of woody vegetation exceeds an arbitrary limit of $95 \%$, (ii) competitive dominance of taller-growing woody PFTs by first reducing herbaceous PFT biomass if tissue growth leads to a grid-cell FPC sum greater than unity.

Finally, note that for this study dynamical nitrogen cycling (Stocker et al., 2013; Spahni et al., 2013) has been turned off.

\subsubsection{Wetland $\mathrm{CH}_{4}$ emissions}

Wetland $\mathrm{CH}_{4}$ emissions are the product of the wetland extent and the $\mathrm{CH}_{4}$ flux density. In LPX, natural wetland $\mathrm{CH}_{4}$ emissions are computed for different classes of wetlands: boreal peatland, inundated wetland and wet mineral soils. Originally, for peatland $\mathrm{CH}_{4}$ emissions, an additional scaling factor was used to account for the peatland microtopography (see Wania et al., 2010; Zürcher et al., 2013). In the present study, such a scaling procedure is not used for tropical floodplains (see Sect. 2.5).

The areal extents of boreal peatlands and inundated wetlands are derived from different maps: soil survey maps derived from Tarnocai et al. (2009), Yu et al. (2010) and Wania et al. (2012) for peatlands and maps of remotely sensed inundation extent given by Prigent et al. (2007) for inundated wetland. The extent of wet mineral soils is defined as the grid-cell fraction that is not occupied by peatland and inundated wetland (and rice), but for which the soil water content is above a given threshold (Spahni et al., 2011). Originally, in LPX, floodplains were included in the inundated wetland class and thus, the extent was not explicitly defined but derived from Prigent et al. (2007). In our approach, however, the floodplain extent is prescribed using outputs of the PCRGLOBWB model (see Sect. 2.2.1).

In previous studies (Spahni et al., 2011; Wania et al., 2010), process-based computation of $\mathrm{CH}_{4}$ flux densities were restricted to the case of boreal peatlands. $\mathrm{CH}_{4}$ flux densities for inundated wetland and wet mineral soils were estimated using scaling factors, such as the simple $\mathrm{CH}_{4} / \mathrm{CO}_{2}$ ratio and $\mathrm{CO}_{2}$ heterotrophic respiration (HR) (Spahni et al., 2011; Wania et al., 2013). A similar approach is used in the LPJ version of Hodson et al. (2011).

In the case of boreal peatlands, the $\mathrm{CH}_{4}$ flux density that escapes to the atmosphere results from three processes: production, oxidation and transport. Water saturation and $\mathrm{O}_{2}$ concentration are key variables for estimating the balance between production and oxidation and thus the resulting $\mathrm{CH}_{4}$ concentration in each soil layer. The $\mathrm{O}_{2}$ transport by diffusion and through plants is explicitly represented in the model. In Wania et al. (2010), the potential carbon pool for methanogenesis is estimated from the heterotrophic respiration (HR). Part of the NPP is attributed to root exudates, which contributes to HR without passing through the litter and soil pools. The potential carbon pool for methanogenesis is distributed over all soil layers, weighted by the root distribution. This carbon is split into $\mathrm{CH}_{4}$ and $\mathrm{CO}_{2}$ depending on a (fixed) maximum ratio and the anoxic status of each soil layer. The anoxic status of each soil layer is computed in LPX as a function of the local soil water content rather than the actual $\mathrm{O}_{2}$ concentration. The dissolved $\mathrm{CH}_{4}$ concentration and the gaseous $\mathrm{CH}_{4}$ fraction are calculated from the amount of $\mathrm{CH}_{4}$ available in each layer. The rate of $\mathrm{CH}_{4}$ oxidation is computed as a function of the $\mathrm{O}_{2}$ concentration. Remaining dissolved $\mathrm{CH}_{4}$ escape to the atmosphere by diffusion either through the soil (saturated or not) or through plant tissue pores (aerenchyma). Gaseous $\mathrm{CH}_{4}$ escape to the atmosphere by ebullition. Thus, as in Wania et al. (2010), a total of three transport processes is accounted for: diffusion, plant-mediated transport and ebullition. The ebullition parameterization makes use of the partial pressure of $\mathrm{CO}_{2}$ for triggering ebullition events, following (Zürcher et al., 2013). Our modifications mainly consist of accounting for the $\mathrm{O}_{2}$ concentration to compute the anoxic status of soil layers and removal of the catotelm/acrotelm distinction in the tropical zone (see Sect. 2.5).

\subsection{Floodplain hydrology}

\subsubsection{Floodplain extent}

Global wetlands vary widely in hydrologic, soil and vegetation characteristics. Floodplains differ fundamentally from other wetland types, such as bogs, mires and fen, which depend on local precipitation and groundwater fluctuations (Mistch and Gosselink, 2000). Floodplains result from temporarily increased river discharge, importing sediment and nutrients from elsewhere. Instead, floodplains tend to have mineral soils and can sustain productive vegetation. The Amazon Basin covers 7 million $\mathrm{km}^{2}$, with floodplains as the dominant type (Hess et al., 2003; Miguez-Macho and Fan, 2012).

To account for the specific conditions encountered in floodplains, a new land unit (LU) "floodplain" was introduced in the LPX model. The new LU allows us to impose the water conditions of floodplains without affecting the water budget of the rest of the grid cell, but prevents accounting for seasonal variation in the wetland extent. This is because in the current LPX version, the area fraction of each LU is updated only once a year. Consequently, seasonal variations in wetland extent are not explicitly represented. Nevertheless, seasonality in the flooding depth is accounted for within the floodplain LU on a daily time step (see Sect. 2.2.3). 
In the Amazon Basin, this new floodplain LU grows or shrinks over time mainly in exchange with the natural vegetation LU, hereafter referred to as the non-floodplain LU. The hydrological conditions (annual-mean extent and seasonally varying water depth) in the LPX floodplain LU are prescribed according to the outputs of PCR-GLOBWB. This hydrological model includes a river-routing routine capable of simulating the hydrology of floodplains (Van Beek and Bierkens, 2009; van Beek et al., 2011). A similar approach using PCRGLOBWB has been used in the PEATLAND-VU model for simulation of $\mathrm{CH}_{4}$ emissions from northern wetlands (Petrescu et al., 2010). The use of a hydrological model instead of remote-sensing measurements (e.g., Papa et al., 2010) allows us to represent the two components of the wetland $\mathrm{CH}_{4}$ emissions (flux density and wetland extent), which can be applied to years for which no inundation data are available. The simulation of floodplain extent may introduce potential biases, in particular because evaluation of model performances is difficult for the Amazon Basin (cf. Discussion).

PCR-GLOBWB is a global hydrological model and has been developed primarily for estimating the availability of fresh water (also called "blue" water) (van Beek and Bierkens, 2009; van Beek et al., 2011; Gleeson et al., 2012). PCR-GLOBWB calculates the water storage on a cell-bycell basis in two vertically stacked soil layers and an underlying groundwater reservoir on a daily time step. The exchange between the soil column and the atmosphere includes rainfall, snowmelt and evaporation from plants and interception. The soil column produces runoff, comprising direct surface runoff, subsurface storm flow and base flow, which is routed as discharge along the drainage network using the kinematic wave approximation for channels. Where interrupted by lakes or reservoirs, parameterized on the basis of the GLWD1 (Lehner and Döll, 2004), discharge is controlled by storage-outflow relationships, including a prognostic operation scheme that optimizes the release of each reservoir (van Beek et al., 2011). In each grid cell containing a river channel, floodplains can form if the simulated channel storage exceeds the capacity at bank-full discharge. The resulting floodplain area and inundation depth follow from the distribution of elevations above the river bed, which is parameterized using the cumulative land area in a cell (subdivisions of $0.01,0.05$ and 0.1 through 1.0 by increments of 0.1 ). The basis of this subdivision is the HYDRO1k (http://gcmd. nasa.gov/records/GCMD_HYDRO1k.html) which provides a global, hydrologically correct elevation data set with a spatial resolution of $1 \times 1 \mathrm{~km}^{2}$. The height of the floodwaters (hereafter "flooding depth") and the extent of the sub-merged area thus follow from intersecting the cumulative floodplain volume with the discharge in excess of channel storage. In terms of variables, for a given day $t$ and a given grid cell, the total volume that is stored in a channel reach of a grid cell (wst), the resulting floodplain extent (fldf) and the flooding depth aboveground (fldd) are given by PCR-GLOBWB. The fldd given by PCR-GLOBWB is always positive or null. The river channel area is subtracted a posteriori from fldf, while the river channel volume is subtracted from wst. Contrary to the earlier application of PCR-GLOBWB to estimate $\mathrm{CH}_{4}$ emissions over northern wetlands (Petrescu et al., 2010), the extent of the floodplain is computed here online, leading to a dynamic interaction between floodplain extent and depth and flood wave propagation as a result of increased resistance compared to bank-full discharge (Winsemius et al., 2013).

In LPX, the annual extent of the floodplain LU per grid cell (fldfmean) is defined as the area that corresponds to the annual mean flood volume (wst) as calculated by PCRGLOBWB (cf. Fig. A1, top and middle panels for an example). Because only two LUs are considered in the present study, changes in the floodplain LU extent are balanced by corresponding changes in the non-floodplain LU.

\subsubsection{Flooding depth seasonality}

The Amazon Basin is characterized by a period of more frequent rain (approximatively from February through April) and a period of less intense rainfall, with the driest period between July and September. This leads to large water level fluctuations and thus seasonality in both floodplain extent and flooding depth. The river level lags behind the seasonal pattern of precipitation by a few months because of storage of water in different water pools (see e.g., Fig. 1 of Bartlett et al., 1990). The Amazon River is mainly monomodal, that is, characterized by a single pulse of flooding per year, contrary to other basins in South America.

As for peatland (Wania et al., 2009b), we computed a water table position (WTP) variable for the floodplain LU. For a given time step, depending on the value of the PCRGLOBWB-derived flooding depth that is prescribed to LPX (fldd LPX $)$, two cases arise:

- if fldd $_{\text {LPX }}$ is equal to 0 , the LPX-computed soil water content is used for the WTP calculation. In this case, WTP is negative, and equal to the difference (expressed in meters) between the maximum and actual soil water content.

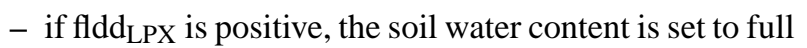
saturation over the floodplain LU and fldd $d_{L P X}$ is used as WTP.

The PCR-GLOBWB-derived flooding depth is consistent with a seasonally varying floodplain extent. In contrast, the simulation of vegetation growth and distribution in LPX is calculated for an annually constant floodplain fraction $\left(\right.$ fldf $\left._{\text {mean }}\right)$. Therefore a method is needed to calculate fldd $_{\mathrm{LPX}}$, which takes into account the neglected seasonality in floodplain extent. Two alternative approaches were implemented and tested in LPX. In the first approach (called "redist" hereafter), the flooding depth varies proportionally with the variation of flood volume (wst) relative to its annual mean. In the second approach (hereafter "product"), the flood depth varies 
a) GLC2000 flooded vegetation

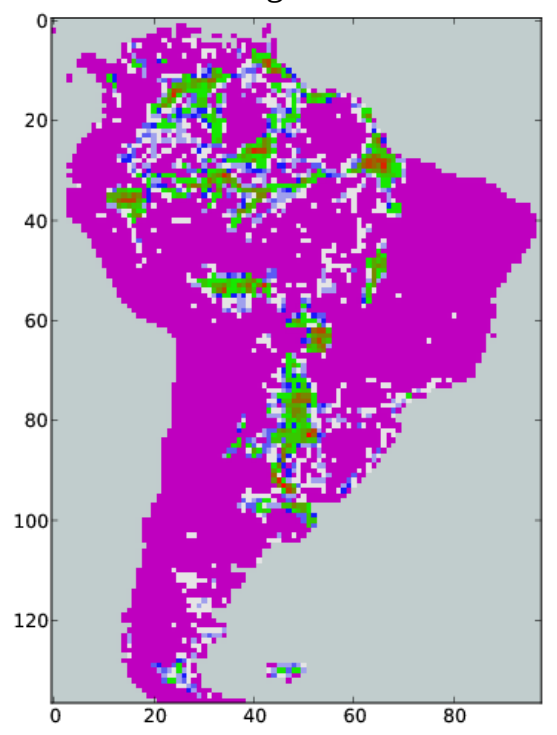

b) PCR-GLOBW floodplains

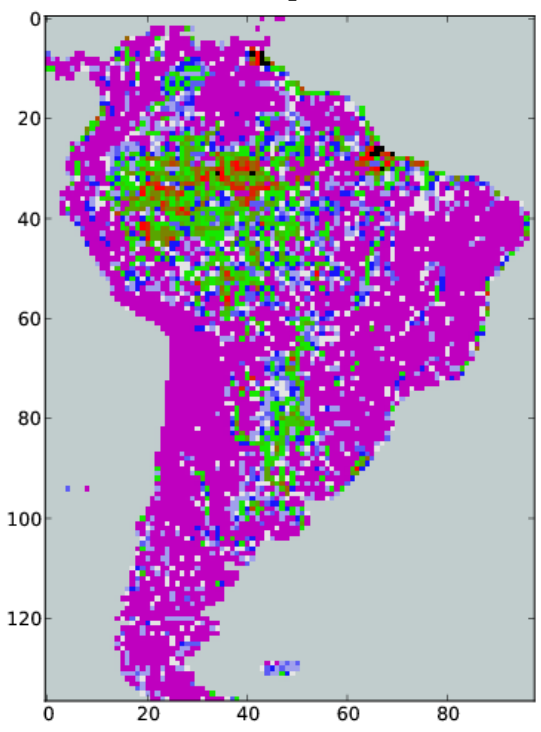

$(-)$

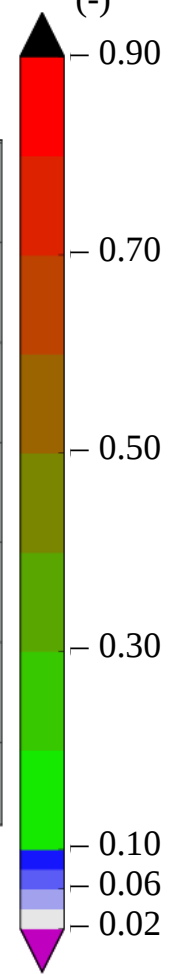

Fig. 1. Fraction of total grid cell at $0.5^{\circ}$ resolution (unitless) covered by (a) flooded vegetation as defined by GLC2000 and (b) floodplain given by PCR-GLOBWB (mean annual value over 1979-2009 of fldf mean). The (b) panel map is used as input of LPX for simulations without year-to-year variability of floodplain extent (simulations 1-6 in Table 5).

proportional to the product of flood depth and flood fraction. This differs from the flood volume, because floodplains have a nonuniform depth. On the other hand, the floodplain LU in LPX has a uniform depth. Approach 2 is a sensitivity test to evaluate the importance of this inconsistency.

In the redist approach, for a given day $t$ and grid cell,

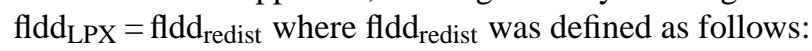

$$
\begin{aligned}
& \text { If } \operatorname{wst}(t) \geq \overline{\mathrm{wst}}, \operatorname{fldd}_{\text {redist }}(t)=\overline{\text { fldd }}+\frac{\mathrm{wst}(t)-\overline{\mathrm{wst}}}{\mathrm{fldf}_{\text {mean }}} \\
& \text { If } \operatorname{wst}(t)<\overline{\mathrm{wst}}, \operatorname{fldd}_{\text {redist }}(t)=\overline{\text { fldd }} \cdot \frac{\mathrm{wst}(t)}{\overline{\mathrm{wst}}},
\end{aligned}
$$

with wst, fldd, fldf respectively in $\mathrm{m}^{3}, \mathrm{~m}$ and $\mathrm{m}^{2}$. Over-lined variables denote annual means.

In the product case, fldd $_{\mathrm{LPX}}=\mathrm{fldd}_{\text {product }}$ as computed in a given year by

$$
\begin{aligned}
& \text { If } \operatorname{fldf}(t) \leq \operatorname{fldf}_{\text {mean }}, \operatorname{fldd}_{\text {product }}(t)=\operatorname{fldd}(t) \cdot \operatorname{fldf}(t) \\
& \text { If } \operatorname{fldf}(t)>\operatorname{fldf}_{\text {mean }}, \operatorname{fldd}_{\text {product }}(t)=\operatorname{fldd}(t) .
\end{aligned}
$$

The two cases (Eqs. 1 and 2) are displayed for a given grid cell in Fig. A1 (bottom panel). The seasonal cycle of fldd redist and fldd product over the whole Amazon Basin are given in Fig. A2. In both cases, a large proportion of the horizontal seasonality (i.e., the seasonality in wetland extent) is trans- ferred into the seasonality of the flooding depth. The seasonality in wetland extents is assumed to be a major driver of the variability in wetland $\mathrm{CH}_{4}$ emissions (Bloom et al., 2010; Ringeval et al., 2010). There are no observations on flooding depth available at large scale. However, we compared the simulated flooding depth to information available on particular sites (Sect. 2.6.3 and Fig. A4). In addition, the effects of the seasonality in the floodplain extent on the simulated $\mathrm{CH}_{4}$ emissions is evaluated in Sect. 3.3 and discussed in Sect. 4.

\subsection{Floodplain vegetation}

As mentioned in Sect. 2.1.2, heterotrophic respiration is used as a proxy for the potential carbon pool for methanogenesis, including contributions from litter/soil carbon and root exudates. In equilibrium, and without accounting for firerelated fluxes, heterotrophic respiration is in balance with NPP. To get NPP right requires a realistic representation of the floodplain vegetation carbon balance in the Amazon Basin. Note also that the vegetation type and structure are important since they influence the $\mathrm{CH}_{4}$ transport pathway from the soil to the atmosphere (diffusion/ebullition vs. plant-mediated transport).

To simulate floodplain vegetation, flood-tolerant tropical PFTs were introduced. This allows incorporating 
flood-related stress on productivity in the model. In addition, we changed the mortality parameterization for trees in the floodplain LU. The aim of these modifications was to improve the representation of (i) the fractional coverage of grasses versus trees and (ii) the floodplain NPP. The grasses/trees contribution to total vegetation was evaluated against the GLC2000 data set. Floodplain NPP was evaluated against MODIS-derived NPP in combination with GLC2000 (see Sect. 2.6.1).

\subsubsection{Flood-tolerant tropical PFTs}

The original model version accounts for three tropical PFTs: tropical broad-leaved evergreen (TrBE), tropical broadleaved raingreen $(\mathrm{TrBR})$ and $\mathrm{C} 4$ grasses $(\mathrm{C} 4 \mathrm{G})$. This approach was extended by defining three new PFTs, which are flood-tolerant versions of the existing tropical PFTs, increasing the total number of natural PFTs in LPX from 10 to 13.

\subsubsection{Photosynthesis}

The flooding of vegetation causes anoxic conditions in the rooting zone, which causes accumulation of ethylene within plants, and lower redox potentials. Eventually, phytotoxins accumulate in the rooting zone, impeding plant growth. To account for this inundation stress, we modified the anoxic stress factor on productivity as introduced by Wania et al. (2009a). The introduced parameterizations are empirical relations to mimic the influence of inundation stress on vegetation productivity and distribution in order to bring these properties into a realistic range. Chosen formulations are similar to Wania et al. (2009a). In a next step, the LPX model could be more deeply modified to be more mechanistic (see Sect. 4). Here, as in Wania et al. (2009a), two PFTspecific parameters are used, namely, a threshold water table $\left(\mathrm{WTP}_{\max }\right)$, above which a PFT experiences inundation, and a maximum survival duration of inundation $\left(t_{\text {inund }}\right)$, which counts how many days a PFT can survive under inundation.

Thus, for a given day $d$ and a given PFT,

$$
\begin{aligned}
& \text { If } \operatorname{WTP}(d) \geq \mathrm{WTP}_{\max }, \operatorname{icount}(d) \\
& \quad=\min \left(t_{\text {inund }}, \operatorname{icount}(d-1)+1\right) \\
& \text { If } \operatorname{WTP}(d)<\mathrm{WTP}_{\text {max }}, \operatorname{icount}(d)=0 .
\end{aligned}
$$

The monthly gross primary production is reduced by icount $/ t_{\text {inund }}$ where icount is the monthly mean value of $\operatorname{icount}(d)$. We assumed that one day with WTP below WTP $_{\max }$ is sufficient to reset the stress to 0 . Contrary to Wania et al. (2009a), the icount variable is not reset to 0 at the beginning of each month in order to avoid unwarranted influences of the division of a year into months, and has an upper limit $\left(t_{\text {inund }}\right)$ to limit the range of icount $/ t_{\text {inund }}$ between 0 and 1 . As in Wania et al. (2009a), the monthly respiration is reduced by this scaling factor.

Besides, the growth of flood-tolerant PFTs is reduced under drought-stress, following treatment of flood-tolerant $\mathrm{C} 3$ graminoids in Wania et al. (2009b). As soon as WTP drops below $-20 \mathrm{~cm}$, flood-tolerant PFTs experience stress and GPP is reduced proportional to WTP by a factor ranging from 0 to 1 for WTPs between $[-20 \mathrm{~cm},-40 \mathrm{~cm}]$. Below $-40 \mathrm{~cm}$, the stress is equal to 1 , corresponding to a primary production of 0 .

The GPP of flood-tolerant PFTs in the non-floodplain LU is reduced as well. A simplified approach is taken, independent of the hydrological conditions encountered in the non-floodplain LU. The prescribed stress corresponds to the drought stress in the floodplain LU at a WTP of $-25 \mathrm{~cm}$. This way, the flood-tolerant PFTs are effectively outcompeted by classical PFTs and the impact of flood-tolerant PFTs on the non-floodplain classical "natural" LU is limited.

To parameterize the flood-tolerant PFTs, we chose representative values for graminoids and flood-tolerant forest trees. While such representative values will never be able to represent the high variability in flooding susceptibility of this diverse ecosystem (Junk and Piedade, 1993; Piedade et al., 2010), we chose a value for emergent $C 4$ grasses with high productivity, dominating the herbaceous Amazon ecosystem, like Echinochloa polystachya and Paspalum repens. In our approach, we did not account for floating macrophytes (e.g., Paspalum fasciculatum) whose specificities (Wassmann et al. 1992) would require a more fundamental recoding of LPX (see Discussion). Nevertheless, the sensitivity of $\mathrm{CH}_{4}$ emissions to key characteristics of floating macrophytes (no plant-mediated transport and no exudates) will be tested in Sect. 2.6.3. Amazon floodplain water is turbid, and in turbid water the submerged grasses cannot photosynthesize. Plant species, such as Echinochloa polystachya, are characterized by high productivity and long shoots to maintain leaves above the water. The higher production potential of $\mathrm{C} 4$ as compared to $\mathrm{C} 3$ plants may explain the dominance of $\mathrm{C} 4$ plants in tropical floodplains (Piedade et al., 1991). Piedade et al. (1991) report shoots longer than $10 \mathrm{~m}$ (see Fig. 1 of Piedade et al., 1991).

The most commonly encountered species of trees are Laetia corymbulosa (evergreen), Crataeva benthamii (deciduous) and Pseudobombax munguba. Most trees species occur both in flooded and in non-flooded ecosystems, except for some species, such as Pseudobombax munguba, which is stem-succulent. Trees are characterized by reduced metabolism during the aquatic phase (Wittmann et al., 2006). Forests tolerate extended periods of flooding, up to $270 \mathrm{~d} \mathrm{yr}^{-1}$ (Wittmann et al., 2002).

Following these descriptions, we chose a higher $\mathrm{WTP}_{\max }$ for flood-tolerant grasses than for flood-tolerant trees, and the opposite pattern for $t_{\text {inund }}$ (i.e., longer for flood-tolerant trees than for flood-tolerant grasses). This parameterization makes trees more adapted to long periods of inundation than grasses, but with an immediate impact on productivity as soon as the flooded conditions are encountered. Grasses are adapted to high WTP. However, as soon as WTP exceeds $\mathrm{WTP}_{\max }$, grass productivity is strongly reduced to account 
for the impact of submergence. Unfortunately, there are no direct observations available to describe how flood duration and flooding depth affect productivity for PFTs in tropical floodplains. Instead, we evaluated the sensitivity of vegetation dynamics and productivity to these parameter settings (see Sect. 3.2). Note also that given values of ( $\mathrm{WTP}_{\max }$, $\left.t_{\text {inund }}\right)$ will have a different effect on vegetation dynamics and productivity depending on the chosen flooding depth description (i.e., fldd product $_{\text {or }}$ fldd $_{\text {redist }}$ ). Negative $\mathrm{WTP}_{\max }$ values (between -100 and $-300 \mathrm{~cm}$ as in Wania, 2007) were assigned to non-flood-tolerant PFTs, ensuring that floodtolerant PFTs are more adapted to flooded conditions.

\subsubsection{Tree mortality}

Mortality corresponds to a reduction in population density and is computed at a yearly timescale (Sitch et al., 2003). Mortality can occur as a result of light competition, a negative annual carbon balance, heat stress or when bioclimatic limits of a PFT are exceeded for an extended period (Sitch et al., 2003). A new mortality term was introduced to represent reduction in population density of flood-tolerant trees in the floodplain LU. This mortality term represents enhanced tree mortality, even of adapted trees upon flooding (BaileySerres and Voesenek, 2008). A constant additional mortality for flood-tolerant trees at flooding, hereafter called $M_{\text {add }}$, is chosen and is used as a tuning parameter (see the next section).

\subsubsection{Soil carbon decomposition}

As for peatlands (Wania et al., 2009a), the sensitivity of carbon decomposition to soil water content $\left(R_{\text {moist }}\right)$ was set to a constant value. While the WTP could occasionally fall below the soil surface (see Sect. 2.2.3), the floodplain LU soil remains almost always saturated, justifying this approach. Under anoxic conditions, decomposition is slow because anoxia limits phenol oxidase activity and causes phenolic compounds to accumulate. For peatlands, $R_{\text {moist }}$ of 0.35 was used. For floodplains, an arbitrary $R_{\text {moist }}$ of 0.5 was chosen to account for a faster anaerobic degradation in floodplains than in peatlands due to a more neutral $\mathrm{pH}$. The $\mathrm{CH}_{4}$ emissions sensitivity to $R_{\text {moist }}$ is discussed in Sect. 4.

\subsection{Year-to-year variability in floodplain extent}

In regional simulation 7 (see Sect. 2.6.3), interannual variation in floodplain extent was accounted for as forced by PCRGLOBWB outputs. This leads to the conversion of land from one LU (called hereafter $\left.\mathrm{lu}_{2}\right)$ to the other $\mathrm{LU}\left(\mathrm{lu}_{1}\right)$ and of the various PFTs accordingly. All variables describing soil and vegetation were converted from one LU to the other. Nonfloodplain and floodplain LU classes use the same PFTs; however, they behave differently in each LU. For any tree PFT of the expanding $\mathrm{LU} \mathrm{lu}_{1}$, the properties (biomass, LAI, crown area, hereafter called variables $V$ ) of a tree individual were modified according to Eq. 4. This equation describes the transfer of any variable $V$ of a given $\mathrm{PFT}_{a}$ in $\mathrm{lu}_{1}$ from year $t$ to year $t+1$ :

$$
\begin{aligned}
& V\left(\mathrm{PFT}_{\mathrm{lu}_{1}, a}, t+1\right)= \\
& \frac{V\left(\mathrm{PFT}_{\mathrm{lu}_{1}, a}, t\right) \cdot A\left(\mathrm{lu}_{1}, t\right) \cdot n\left(\mathrm{PFT}_{\mathrm{lu}_{1}, a}, t\right)+\sum_{b \in L} \Delta A \cdot V\left(\mathrm{PFT}_{\mathrm{lu}_{2}, b}, t\right) \cdot n\left(\mathrm{PFT}_{\mathrm{lu}_{2}, b}, t\right)}{A\left(\mathrm{lu}_{1}, t+1\right) \cdot n\left(\mathrm{PFT}_{\mathrm{lu}_{1}, a}, t+1\right)},
\end{aligned}
$$

with $\Delta A=A\left(\mathrm{lu}_{1}, t+1\right)-A\left(\mathrm{lu}_{1}, t\right)>0$, and where, at time $t, A\left(\mathrm{lu}_{X}, t\right)$ is the extent of the $\operatorname{lu}_{X} \mathrm{LU} ; n\left(\mathrm{PFT}_{Y}, t\right)$ is the number of individual trees for the $\mathrm{PFT}_{Y}$, and $L$ is the list of PFTs in $\mathrm{lu}_{2}$ "corresponding" to $\mathrm{PFT}_{\mathrm{lu}_{1}, a}$. Indeed, each PFT is characterized by a rank defining it among the 13 possible PFTs (second subscript corresponding to, e.g., TrBE, TrBR, C4G, flood-tolerant TrBR, etc.) and the LU in which it grows (first subscript corresponding to floodplains or nonfloodplains). As a first approach, we chose to make each PFT correspond to the same PFT of the other LU (i.e., $L=\{a\}$ in Eq. 4). For instance, if the floodplain LU shrinks $\left(\operatorname{lu}_{2}=\operatorname{lu}_{\text {flood }}\right.$ in Eq. 4), $\operatorname{TrBR}$ of the floodplain LU is converted into $\mathrm{TrBr}$ of non-floodplain LU. The modifications introduced in LPX to simulate floodplains alter the forest characteristics: for example, floodplain forests are characterized by a large number of small trees, while non-floodplain forests consist of a smaller number of larger trees. Due to these differences, any conversion from one LU to the other leads to a high mortality in the tree population. This can happen for flood-tolerant PFTs that experience stress on the classical natural LU when floodplain extent shrinks.

The different litter and soil carbon pools, as well as the number of individual trees after conversion of a given fraction of $l_{1} u_{1}$ to $\mathrm{lu}_{2}$, were computed following an equation similar to Eq. 4. However, these variables were not computed for the average individual in the model and thus no weighting by the number of individuals is necessary. Instead, a simple mean of the given variables of two corresponding PFTs was taken and weighted by the extent of $l_{1}$ and $\Delta A$. Finally, in the first attempt, the LU conversion did not account for redistribution of water in order to prevent any major modifications in the non-floodplain LU.

\subsection{Extension of the $\mathrm{LPX} \mathrm{CH}_{4}$ module to floodplains}

Since the main processes leading to $\mathrm{CH}_{4}$ emissions (production, oxidation and transport) are common to all wetlands, only a limited number of modifications of the original $\mathrm{CH}_{4}$ emission routine were needed in order to adapt it for floodplain $\mathrm{CH}_{4}$ emissions. Except for the introduction of a methanogenesis reduction in the presence of $\mathrm{O}_{2}$, which is considered a generic process-based improvement, all other modifications were needed to make the $\mathrm{CH}_{4}$ routine consistent with the implemented LPX representation of floodplain vegetation.

In Wania et al. (2010), the potential carbon pool for methanogenesis is split into $\mathrm{CO}_{2}$ and $\mathrm{CH}_{4}$ as function of (i) the $\mathrm{CH}_{4} / \mathrm{CO}_{2}$ ratio under fully total anoxic conditions 
(hereafter called $r_{\mathrm{CH}_{4} / \mathrm{CO}_{2}}$ and equal to 0.10 ), and (ii) the degree of anoxia of each soil layer. The degree of anoxia of each soil layer is computed by using the soil water content: $1-f_{\text {air }}$, where $f_{\text {air }}$ is the fraction of air in each layer. Here we introduce a decrease of methanogenesis in the presence of $\mathrm{O}_{2}$ in such a way that the degree of anoxia is now approximated by

anoxia $=1-\left(f_{\mathrm{air}}+\left(1-f_{\mathrm{air}}\right) \cdot \frac{\left[\mathrm{O}_{2}\right]}{\left[\mathrm{O}_{2}\right]_{\mathrm{eq}}}\right)$,

where $\left[\mathrm{O}_{2}\right]$ is the computed and dissolved $\mathrm{O}_{2}$ concentration of the given soil layer and $[\mathrm{O} 2]_{\mathrm{eq}}$ is the dissolved concentration that is in Henry's equilibrium with the atmosphere. This modification makes the anoxia computation related to the oxygen concentration (and not to air fraction alone), which is more in agreement with basic knowledge about methanogenesis (Conrad et al., 1989).

As underlined in previous sections, we treated floodplains as mineral soils in LPX. That means that no distinction between catotelm/acrotelm was made in the floodplain LU. Also porosity was based on a soil texture map as for other mineral soils instead of using constant porosity and minimum gas fraction for peatlands as in Wania et al. (2010). No thresholds on porosity were applied to allow ebullition. All flood-tolerant PFTs contribute to methanogenesis substrate. However, only the flood-tolerant $\mathrm{C} 4$ plants contribute to plant-mediated transport. Root distribution with depth is kept as in Wania et al. (2010). Note also that, as in Wania et al. (2010), the water column above the soil surface is added to the top soil layer, even though this is less appropriate for large flooding depths (see discussion).

Table A1 summarizes the meaning of main variables/parameters introduced in LPX.

\subsection{Experimental set-up and data sets used for evaluation}

\subsubsection{Floodplain extent}

As outlined above, we defined the annual extent of the floodplain LU per grid cell (fldfmean) as the area that corresponds to the annual mean flood volume (wst) as calculated by PCRGLOBWB (cf. Fig A1, top and middle panels for an example). PCR-GLOBWB was implemented on a spatial grid of $0.5^{\circ}$ at a daily time step. For these simulations, we made use of the ERA-Interim reanalysis (Dee et al., 2011) to force the model with precipitation, temperature and reference potential evapotranspiration over the period 1979-2009, for which the fields were gridded at the required spatial and temporal resolution. This reanalysis data set has limited qualities in reproducing the hydrological cycle, mainly because precipitation is not included in the data assimilation scheme. Therefore, a scaled precipitation product was chosen which corrects the ERA-interim precipitations using the GPCP observational data set (Balsamo et al., 2011). This correction, however, is coarse ( 2.5 degrees), resulting in a relatively poor performance over highly variable terrain. Therefore, as an additional correction, all forcing variables (precipitation, evapotranspiration and temperature) were scaled to bring their long-term means in accordance with the CRU TS 2.1 (New et al., 2002). This correction was applied on a month-by-month basis for time period of the CRU data set (1971-2001) and regions where stations were available.

The model was spun-up by iteratively updating the longterm components of the groundwater system over a period of 10 years followed by a transient simulation. This was then repeated by a full run over the entire simulation period to initialize the stores of the routing model (channels, reservoirs and lakes). This simulation strategy closely follows that of Van Beek et al. (2011), who used the CRU TS2.1 data set directly to force the model. Although different climatological data were used, the long-term means over gauged areas are similar. Therefore, the validation exercise undertaken by Van Beek et al. (2011) and the limitations that were found are expected to apply to our model as well.

To evaluate the land cover as simulated using the combined LPX-PCR-GLOBWB set-up, we made use of the Global Land Cover 2000 (GLC2000 hereafter) land cover map (http://bioval.jrc.ec.europa.eu/products/glc2000/ products.php). GLC2000 is based on multi-resolution satellite data (combining 4 independent data sets) and provides the dominant vegetation type, among 40 classes, for each $0^{\circ} 0^{\prime} 32.1444^{\prime \prime}$ latitude $\times 0^{\circ} 0^{\prime} 32.1444^{\prime \prime}$ longitude grid cell. We made use of the regional data set for South America (The Land Cover Map for South America in the Year 2000, 2003).

To compare to PCR-GLOBWB, for each $0.5 \times 0.5^{\circ}$ grid cell $g$, the floodplain extent was estimated by counting all GLC2000 grid cells at GLC2000 resolution within $g$ covered by any of the following vegetation classes: "fresh water flooded forests", "permanent swamp forests", "periodically flooded shrublands" or "periodically flooded savannah". The GLC2000 class "water bodies" was not used, since it represents lakes and water channels, rather than floodplains. Floodplain fractions were compared to the long-term mean (i.e., 1979-2009) fldf $_{\text {mean }}$.

\subsubsection{Floodplain vegetation}

Three LPX simulations were performed at $0.5^{\circ}$ resolution with different sets of values for fldd, $\mathrm{WTP}_{\max }, t_{\text {inund }}$ and $M_{\text {add }}$ (Table 1). For each simulation, the Climate Research Unit (CRU) TS 3.0 climate data set (Mitchell and Jones, 2005) was used with monthly input data for surface air temperature, total precipitation, sunshine hours from fractional cloud cover, and number of wet days. The used soil data set was the Harmonized World Soil Database (HWSD, version 1.0., FAO/IIASA/ISRIC/ISSCAS/JRC, 2009). The following procedure was used for the LPX simulations: first, a spin-up of 1500 years was conducted, by recycling the input 
Table 1. Different combinations of (fldd, $\mathrm{WTP}_{\max }, t_{\text {inund }}$ and $\left.M_{\mathrm{add}}\right)$. Only the values of $\left(\mathrm{WTP}_{\max }, t_{\text {inund }}, M_{\text {add }}\right)$ for flood-tolerant trees vary from one simulation to the other. For all simulations, $\left(\mathrm{WTP}_{\max }, t_{\text {inund }}\right)$ for flood-tolerant grasses are set to $(10 \mathrm{~m}, 10 \mathrm{days}) . M_{\text {add }}$ has a meaning only for tree PFTs (no population density for grass PFTs).

\begin{tabular}{lllll}
\hline $\begin{array}{l}\text { (fldd, } \mathrm{WTP}_{\max }, \\
\begin{array}{l}\left.t_{\text {inund }}, M_{\text {add }}\right) \\
\text { combination } \\
\text { number }\end{array}\end{array}$ & fldd & $\begin{array}{l}\mathrm{WTP}_{\max } \text { in } \\
\text { meters for } \\
\text { flood-tolerant } \\
\text { trees }\end{array}$ & $\begin{array}{l}t_{\text {inund }} \text { in } \\
\text { days for } \\
\text { flood-tolerant } \\
\text { trees }\end{array}$ & $\begin{array}{l}M_{\text {add }} \\
\text { (without } \\
\text { unit) }\end{array}$ \\
\hline 1 & fldd $_{\text {product }}$ & 0.1 & 150 & +0.05 \\
2 & fldd $_{\text {product }}$ & 0.6 & 150 & +0.1 \\
3 & fldd $_{\text {redist }}$ & 0.2 & 250 & +0.008 \\
\hline
\end{tabular}

data for the 1901-1931 period. Then, a transient run was performed for the 1931-2009 period. In the Results section, we focus on the 1990-2009 period. For all simulations, except for regional simulation 7 (see Sect. 2.6.3), both spin-up and transient runs were performed without IAV in the floodplain LU extent. Thus, the 1979-2009 climatology of PCRGLOBWB outputs was used to prescribe floodplain extents. Note that the climate data sets used to force LPX and PCRGLOBWB are not the same. The correction of ERA-Interim to CRU TS 2.1, described in the previous section, accounts largely for differences in the long-term mean. However, at smaller spatial and temporal scales inconsistencies are expected to be more important, in particular because of the low observational coverage over parts of the Amazon Basin.

We compared both the simulated grasses/trees contribution to total vegetation and the simulated-floodplain NPP against observations to evaluate whether our modifications capture the floodplain vs. non-floodplain patterns well.

Besides floodplain extent, GLC2000 was used for evaluating the LPX-simulated fractional vegetation cover of floodplain grasses, floodplain trees, non-floodplain grasses and non-floodplain trees (see Sect. 2.3). For this purpose, the LPX floodplain tree cover was compared to the sum of all the GLC2000 classes listed in Sect. 2.6.1 while "Periodically flooded savannah" was used to evaluate the fraction of flooded grasses in LPX. All other natural tree and grass classes were used to evaluate the non-floodplain grass and tree fractions in LPX at $0.5^{\circ}$ resolution. For LPX, vegetation cover is calculated by summing the FPCs of the PFTs to be compared.

Floodplain NPP was evaluated against the MODerate Resolution Imaging Spectroradiometer (MODIS)-derived NPP. We made use of GLC2000 to identify the location of floodplain ecosystems, extracting the NPP of floodplain ecosystems only. This approach assumes that, at a $0.5^{\circ}$ resolution, the differences in NPP between the floodplain and nonfloodplain LUs are explained by the flooding conditions. MODIS-NPP was obtained from the Numerical Terradynamic Simulation Group (NTSG) (Zhao and Running, 2010; Zhao et al., 2005) (http://www.ntsg.umt.edu). We regridded MODIS-derived NPP to the GLC2000 grid. Then, for each grid cell at LPX resolution, NPP was estimated for different ecosystem types (floodplain and non-floodplain) as well as for the two vegetation meta-classes (grasses and trees) in these ecosystems. To do so, the GLC2000 maps were used to identify the ecosystem and vegetation type of each MODIS grid cell at GLC2000 resolution. Figure A3 displays the resulting NPP maps at GLC2000 resolution, for the quadrant along the main Amazon River defined in Hess et al. (2003). This approach has the following limitations:

- The MODIS data coverage in the Amazon region is strongly limited by cloud cover, which requires gapfilling (Zhao et al., 2005).

- Inconsistencies between MODIS-derived NPP and GLC2000 could occur due to the different resolutions and projections (sinusoidal and regular cylindrical) of the original data sets.

- In MODIS, no NPP values are provided for grid cells corresponding to water bodies, which are set to zero. Note that this mainly concerns the main stem of rivers and lakes, rather than the floodplains themselves. By changing the resolution of the MODIS-derived NPP maps, the missing values influence partially overlapping grid cells. This "contamination" is likely to be larger for floodplain than non-floodplain ecosystems, as they are closer to water bodies. This introduces some underestimation of floodplain NPP, but given the overall uncertainty of the approach this is still considered acceptable.

The main stem of the Amazon River in Brazil is called the Solimoes River upstream from its confluence with the Negro River at Manaus. Hydrologic regimes, vegetation cover and nutrient status differ between the Solimoes River, the Negro River and the main Amazon stem after Manaus (e.g., Junk and Furch, 1993). The Solimoes River region is also called white Amazon (or varzeas) and is characterized by a neutral $\mathrm{pH}$ and a relatively high concentration of dissolved solids (clay) leading to high fertility. In contrast, the Negro River region is called black and clear Amazon (or igapos) and is characterized by a lower $\mathrm{pH}$, low concentration of dissolved 
solids (sand) and thus, lower fertility (cf. the Fig. 1 of Junk et al., 2011). This difference in fertility is related to a difference in phosphorus supply (Arago et al., 2009). This leads to differences in vegetation cover (e.g., Belger et al. (2010) and see Sect. 4) and productivity between varzeas and igapos along a west to east gradient (e.g., Gloor et al., 2012). For instance, the diameter-increment growth rates of trees are up to two-thirds lower in igapos than those found in varzeas forests (Schöngart et al., 2010).

Only recently, LSMs started to include phosphorus dynamics (Goll et al., 2012). This is not yet the case for the LPX model, which may influence the comparison between the MODIS and LPX-derived NPP of Amazon floodplains. The influence of a neglect of phosphorus dynamics and other shortcomings in the LPX-simulated floodplain NPP is quantified by the following ratio:

$a_{\mathrm{NPP}}(g)=\operatorname{NPP}_{\text {MODIS }}^{\text {non-flood }}(g) / \operatorname{NPP}_{\mathrm{LPX}}^{\text {non-flood }}(g)$,

which has been computed for each grid cell $g$ using the mean annual non-floodplain NPP over the 2000-2009 period. To evaluate the sensitivity of LPX-simulated $\mathrm{CH}_{4}$ fluxes to uncertainties in NPP (i.e., $a_{\text {npp}}$ ), a second set of simulations were performed (see Table 1) in which the LPX-computed NPPs for both floodplain and non-floodplain LUs were corrected using $a_{\mathrm{NPP}}$. The scaling factors were applied in LPX at each time step and for all years from the beginning of the spin-up.

\subsection{3 $\mathrm{CH}_{4}$ emissions}

For the estimation of $\mathrm{CH}_{4}$ emissions, LPX simulations were performed at two spatial scales: the site scale and the Amazon Basin scale. LPX-simulated $\mathrm{CH}_{4}$ flux densities and $\mathrm{CH}_{4}$ emissions were compared to available information from observations at different sites and to results of bottom-up models participating in the WETCHIMP intercomparison (Melton et al., 2013; Wania et al., 2013).

\section{Simulations at individual sites}

LPX simulations were performed for five grid cells in the Amazon Basin, where measurements of floodplain $\mathrm{CH}_{4}$ flux densities are available, using the same simulation set-up as discussed in Sect. 2.6.2. Only a few studies report measurements from floodplains in this region of the world. All these sites were used for sensitivity analysis and model evaluation. Table 2 gives the main characteristics of each site, including its coordinates, the period of measurements, some technical information about the measurements, as well as vegetation cover at the sampled locations. Among the sites, three are located in the Negro River floodplain (sites 1, 2 and 3; Belger et al., 2010) and two other sites (site 4, Wassman et al., 1992, and site 5, Bartlett et al., 1988) are located in the central Amazon about $80 \mathrm{~km}$ from Manaus. At all sites, measurements were performed using flux chambers, funnels and/or through determination of gas concentration in air and water. Thus, they are representative of a very small spatial scale (the typical chamber area is $0.2 \mathrm{~m}^{2}$ ).

All sites classify as a floodplain, despite the fact that some are referred to as "floodplain lake" or "lake" in the literature. For example, Marani and Alvalá (2007) (Supp. Site 2) define a "lake" as a permanently flooded area. Usually, measurements of $\mathrm{CH}_{4}$ flux densities are given for different vegetation cover (emergent grasses, floating macrophytes, shrubs or forest) as well as for non-vegetated spots (i.e., open water). All selected five sites include information about $\mathrm{CH}_{4}$ flux densities for at least one vegetated spot. No information about the grass cover (emergent or floating) of the measured plots is available for any of the sites.

In addition, LPX simulations were performed for three additional sites (cf. the last three lines of Table 2). These sites are used in Sect. 4 to evaluate the ability of our modified LPX version to simulate emission from open-water bodies and emissions outside of the Amazon Basin.

All simulations were compared to observation for those years for which measurements are available (Table 2). $\mathrm{CH}_{4}$ fluxes are evaluated on annual or sub-annual timescales. A sensitivity analysis is performed using six different settings, including an "optimal" simulation (Table 3). Each of the settings was compared to the site observations. The simulations mainly vary in vegetation cover, flooding depth and the application of the NPP scaling factor $\left(a_{\mathrm{NPP}}\right)$. The first three simulations were performed for the three parameter combinations defined in Table 1. Vegetation was either computed by LPX or prescribed through modifications of $\mathrm{WTP}_{\max }, t_{\text {inund }}$ and $M_{\text {add. }}$. To prescribe grasses, $M_{\text {add }}$ was set to 1 . To prescribe trees at their maximum cover (95\% of the grid cell), WTP $\max$ and $t_{\text {inund }}$ of trees are set equal to the values of flood-tolerant grasses and $M_{\text {add }}$ was set to 0 . Note, however, that this strategy slightly modifies the inundation stress value. Available information about the observed flood level on site was used to prescribe the flood level in LPX for simulations 2-7 (see Fig. A4). The "optimal" simulation uses conditions that are as close as possible to reality. These conditions vary among sites as described in Table 4.

The "optimal" simulations for sites 1 and 2 include a modification in the root profile and soil porosity according to Belger et al. (2010). For sites 4 and 5, the "optimal" simulation aims at evaluating the sensitivity of the simulated $\mathrm{CH}_{4}$ flux densities to some floating macrophyte properties, namely a suppression of the transport by plants and the fraction of NPP going to exudates set to 0 .

\section{Simulations for the Amazon Basin}

The set-up of simulations performed for the Amazon Basin is summarized in Table 5. The simulations mainly differ in vegetation characteristics $\left(\mathrm{WTP}_{\max }, t_{\text {inund }}\right.$ and $\left.M_{\mathrm{add}}\right)$, the parameterization of flooding depth ( $\left(\right.$ fldd $_{\text {product }}$, fldd redist $)$, the use of the NPP-scaling factor $\left(a_{\mathrm{NPP}}\right)$ and the way to account 
Table 2. Description of sites used for sensitivity analysis and $\mathrm{CH}_{4}$ flux density evaluation. The three Supp. Sites will be used to discuss the ability of the here-developed LPX version to simulate open-water emissions and floodplain emissions outside of the Amazon Basin. Blank cells mean that no information is available and SFC refers to "static floating chamber".

\begin{tabular}{|c|c|c|c|c|c|c|c|c|c|}
\hline $\begin{array}{l}\text { Site } \\
\text { no. }\end{array}$ & Name & Reference(s) & $\begin{array}{l}\text { Coordi- } \\
\text { nates }\end{array}$ & Brief description & $\begin{array}{l}\text { Period (and } \\
\text { frequency) of } \\
\text { measurements }\end{array}$ & $\begin{array}{l}\text { Methods of } \\
\text { measurements }\end{array}$ & $\begin{array}{l}\text { Technique to } \\
\text { separate ebullition } \\
\text { and diffusion }\end{array}$ & $\begin{array}{l}\text { Vegetation } \\
\text { covering of } \\
\text { spots }\end{array}$ & $\begin{array}{l}\text { Information about } \\
\text { flood level }\end{array}$ \\
\hline 1 & Cuini & $\begin{array}{l}\text { Belger et al. } \\
\text { (2011) }\end{array}$ & $\begin{array}{l}0^{\circ} 69^{\prime} \mathrm{S} \\
63^{\circ} 57^{\prime} \mathrm{W}\end{array}$ & $\begin{array}{l}\text { interfluvial wetland } \\
\text { in the Negro River } \\
\text { basin }\end{array}$ & $\begin{array}{l}\text { monthly during } \\
\text { the year } 2005\end{array}$ & $\begin{array}{l}\text { SFC and inver- } \\
\text { ted tunnels when } \\
\text { habitats were } \\
\text { flooded (as well } \\
\text { as terrestrial } \\
\text { chambers when } \\
\text { the environment } \\
\text { was unflooded); } \\
\text { measures of } \mathrm{CH}_{4} \\
\text { concentration in } \\
\text { water }\end{array}$ & $\begin{array}{l}\text { inverted funnels } \\
\rightarrow \text { ebullition; static } \\
\text { floating chambers } \\
\rightarrow \text { diffusion; diffu- } \\
\text { sive fluxes also esti- } \\
\text { mated using Fick's } \\
\text { law and measures } \\
\text { of } \mathrm{CH}_{4} \text { concentra- } \\
\text { tion in water }\end{array}$ & $\begin{array}{l}\text { open water, } \\
\text { emergent grasses, } \\
\text { shrubs }\end{array}$ & $\begin{array}{l}\text { permanently flooded; no } \\
\text { more than } 0.6 \mathrm{~m} \text { deep }\end{array}$ \\
\hline 2 & Itu & & $\begin{array}{l}0^{\circ} 29^{\prime} \mathrm{S} \\
63^{\circ} 45^{\prime} \mathrm{W}\end{array}$ & & & & & $\begin{array}{l}\text { open water, } \\
\text { emergent grasses, } \\
\text { shrubs, palms }\end{array}$ & $\begin{array}{l}\text { dried several months per } \\
\text { year; up to } 1.3 \mathrm{~m}\end{array}$ \\
\hline 3 & Araca & & $\begin{array}{l}0^{\circ} 19^{\prime} \mathrm{N} \\
63^{\circ} 21^{\prime} \mathrm{W}\end{array}$ & & & & & $\begin{array}{l}\text { open water, } \\
\text { emergent grasses, } \\
\text { shrubs, forests }\end{array}$ & $\begin{array}{l}\text { dried several months per } \\
\text { year; up to } 0.8 \mathrm{~m} \text { deep }\end{array}$ \\
\hline 4 & $\begin{array}{l}\text { Isla } \\
\text { Marchan- } \\
\text { taria }\end{array}$ & $\begin{array}{l}\text { Wassman et al. } \\
(1992)\end{array}$ & $\begin{array}{l}3^{\circ} 13^{\prime} \mathrm{S} \\
59^{\circ} 55^{\prime} \mathrm{W}\end{array}$ & $\begin{array}{l}\text { a "floodplain lake" } \\
\text { located on an island } \\
\text { in the Amazon } \\
\text { main channel } \\
\text { (Varzea) about } \\
15 \mathrm{~km} \text { south of } \\
\text { Manaus }\end{array}$ & $\begin{array}{l}\text { monthly during } \\
\text { Apr 1988- } \\
\text { Apr } 1989\end{array}$ & $\mathrm{SFC}$ & $\begin{array}{l}\text { sudden deviation in } \\
\text { the increase of mea- } \\
\text { sured concentration } \\
\text { after closure of the } \\
\text { static chamber is } \\
\text { attributed to ebulli- } \\
\text { tion phenomenon }\end{array}$ & $\begin{array}{l}\text { open water, } \\
\text { floating macro- } \\
\text { phytes and } \\
\text { flooded forest }\end{array}$ & $\begin{array}{l}\text { one value per month (see } \\
\text { Fig. A4) but varies among } \\
\text { the sites into the flood- } \\
\text { plain lake ("temporarily } \\
\text { subaerial" vs. "permanent } \\
\text { aquatic" sites) }\end{array}$ \\
\hline 5 & $\begin{array}{l}\text { Marrecao/ } \\
\text { Pesqueiro/ } \\
\text { Cabaliana/ } \\
\text { Lago } \\
\text { Colado }\end{array}$ & $\begin{array}{l}\text { Bartlett et al. } \\
\text { (1988) }\end{array}$ & $\begin{array}{l}3^{\circ} 15^{\prime} \mathrm{S} \\
60^{\circ} 75^{\prime} \mathrm{W}\end{array}$ & $\begin{array}{l}\text { sites closed to Lago } \\
\text { Calado (cf. Supp. } \\
\text { Site 1) }\end{array}$ & $\begin{array}{l}\text { some days } \\
\text { during Jul-Aug } \\
1985\end{array}$ & $\begin{array}{l}\text { SFC as well as } \\
\text { discontinuous } \\
\text { measurements } \\
\text { using air sampling } \\
\text { from the headspace } \\
\text { of the same floating } \\
\text { chambers }\end{array}$ & $\begin{array}{l}\text { SFC: sudden devi- } \\
\text { ation is attributed } \\
\text { to ebullition pheno- } \\
\text { menon. No distinc- } \\
\text { tion in the discon- } \\
\text { tinuous measure- } \\
\text { ments }\end{array}$ & $\begin{array}{l}\text { floating grass } \\
\text { macrophytes; } \\
\text { flooded forest }\end{array}$ & $\begin{array}{l}\text { values given for a subset of } \\
\mathrm{CH}_{4} \text { measurement in two } \\
\text { habitats of Cabaliana }\end{array}$ \\
\hline \multirow[t]{3}{*}{$\begin{array}{l}\text { Supp. } \\
\text { Site } 1\end{array}$} & $\begin{array}{l}\text { Lago } \\
\text { Colado }\end{array}$ & $\begin{array}{l}\text { Crill et al. } \\
(1988)\end{array}$ & $\begin{array}{l}3^{\circ} 15^{\prime} \mathrm{S} \\
60^{\circ} 34^{\prime} \mathrm{W}\end{array}$ & $\begin{array}{l}\text { lake of about } 6 \mathrm{~km}^{2} \\
\text { area in the central } \\
\text { Amazon Basin } \\
\text { located on the } \\
\text { north side of the } \\
\text { Solimões River, } \\
80 \mathrm{~km} \text { upriver from } \\
\text { its confluence with } \\
\text { the Negro River }\end{array}$ & $\begin{array}{l}\text { Monthly during } \\
\text { Jul-Aug } 1985\end{array}$ & $\begin{array}{l}\text { SFC as well as } \\
\text { discontinuous } \\
\text { measurements } \\
\text { using air sampling } \\
\text { from the headspace } \\
\text { par of the same } \\
\text { floating chambers }\end{array}$ & $\begin{array}{l}\text { SFC: sudden devi- } \\
\text { ation is attributed } \\
\text { to ebullition pheno- } \\
\text { menon. No distinc- } \\
\text { tion in the discon- } \\
\text { tinuous measure- } \\
\text { ments }\end{array}$ & open water & $\begin{array}{l}\text { dry season; Jul: } 8.8 \mathrm{~m} \text {; Aug: } \\
6.6 \mathrm{~m}\end{array}$ \\
\hline & & $\begin{array}{l}\text { Engle and } \\
\text { Melack, } 2000\end{array}$ & & & $\begin{array}{l}\text { daily during } \\
\text { two periods: } \\
\text { 18 Apr-27 May } \\
1987 \text { and } 14- \\
24 \text { Sep } 1987\end{array}$ & $\begin{array}{l}\text { Apr-May: mea- } \\
\text { sures of surface } \\
\text { water } \mathrm{CH}_{4} \text { concen- } \\
\text { trations }\end{array}$ & $\begin{array}{l}\text { only diffusive } \\
\text { flux estimated } \\
\text { through empirical } \\
\text { expressions }\end{array}$ & & Apr-May: rising waters \\
\hline & & & & & & $\begin{array}{l}\text { Sep: SFC and mea- } \\
\text { sures of surface } \\
\text { water } \mathrm{CH}_{4} \text { concen- } \\
\text { tration }\end{array}$ & $\begin{array}{l}\text { diffusive flux esti- } \\
\text { mated through em- } \\
\text { pirical expres- } \\
\text { sions; ebullition } \\
=\text { difference bet- } \\
\text { ween estimated } \\
\text { diffusive flux and } \\
\text { measures with SFC }\end{array}$ & & Sep: falling waters \\
\hline $\begin{array}{l}\text { Supp. } \\
\text { Site } 2\end{array}$ & $\begin{array}{l}\text { Spot in } \\
\text { Pantanal } \\
\text { wetland }\end{array}$ & $\begin{array}{l}\text { Marani and } \\
\text { Alvala (2007) }\end{array}$ & $\begin{array}{l}19^{\circ} 19^{\prime} \mathrm{S}- \\
19^{\circ} 34^{\prime} \mathrm{S} \\
57^{\circ} 00^{\prime} \mathrm{W}- \\
57^{\circ} 03^{\prime} \mathrm{W}\end{array}$ & $\begin{array}{l}\text { two "lakes" (per- } \\
\text { manent flooded } \\
\text { areas: Medalha } \\
\text { and Mirante) and } \\
\text { three floodplains } \\
\text { (flooded seaso- } \\
\text { ally: Arara-Azul, } \\
\text { Bau, Sao Joao) in } \\
\text { the Pantanal region }\end{array}$ & $\begin{array}{l}\text { five campaigns } \\
\text { between } \\
\text { Mar } 2004 \text { and } \\
\text { Mar } 2005\end{array}$ & SFC & $\begin{array}{l}\text { sudden deviation in } \\
\text { the increase of mea- } \\
\text { sured concentration } \\
\text { after closure of the } \\
\text { static chamber is } \\
\text { attributed to ebulli- } \\
\text { tion phenomenon }\end{array}$ & $\begin{array}{l}\text { floating macro- } \\
\text { phytes and open } \\
\text { water }\end{array}$ & $\begin{array}{l}\text { Large variability between } \\
\text { the sites of "lake" (perma- } \\
\text { nently flooded) and "flood- } \\
\text { plains". Flood depth of } \\
\text { more than } 2.4 \mathrm{~m} \text { found in } \\
\text { only one site (Medalha } \\
\text { lake). We assumed maxi- } \\
\text { mum flood depth for } \\
\text { others sites close to } 1.6 \mathrm{~m} \text {. } \\
\text { Dry conditions in one site } \\
\text { (Sao Jao) during December } \\
\text { campaign which does not } \\
\text { allow any measurements. }\end{array}$ \\
\hline $\begin{array}{l}\text { Supp. } \\
\text { Site } 3\end{array}$ & $\begin{array}{l}\text { Spot in } \\
\text { Panama }\end{array}$ & $\begin{array}{l}\text { Keller et al. } \\
\text { (1990), Table } 1 \\
\text { of Barlett and } \\
\text { Harris (1993) } \\
\text { and Walter and } \\
\text { Heimann (2000) }\end{array}$ & $\begin{array}{l}9^{\circ} 30^{\prime} \mathrm{N} \\
79^{\circ} 96^{\prime} \mathrm{W}\end{array}$ & $\begin{array}{l}\text { swamp and flood } \\
\text { forest located in } \\
\text { Panama }\end{array}$ & 1986 & & & $\begin{array}{l}\text { grasses and } \\
\text { flooded forest }\end{array}$ & $\begin{array}{l}\text { Not observed but from } \\
\text { personal communication } \\
\text { quoted in Walter and } \\
\text { Heimann }(2000) \text { : dry } \\
\text { period between Feb and } \\
\text { Mar. Not exceeding } \\
+30 \mathrm{~cm} \text {. }\end{array}$ \\
\hline
\end{tabular}


Table 3. Set-up for simulations on sites. The parameter combinations (WTP ${ }_{\max }, t_{\text {inund }}$ and $\left.M_{\text {add }}\right)$ refer to Table 1 . "Trees"-prescribed vegetation means that forest occupies $95 \%$ of the grid cell (see text).

\begin{tabular}{|c|c|c|c|c|c|}
\hline $\begin{array}{l}\text { Simulations on } \\
\text { sites number }\end{array}$ & $\begin{array}{l}\text { Sub- } \\
\text { class }\end{array}$ & $\begin{array}{l}\text { Parameters combination for flood-tolerant trees no. } \\
\text { (numbers refer to Table } 1 \text { ) }\end{array}$ & $\begin{array}{l}\text { Vege- } \\
\text { tation }\end{array}$ & Flood depth & NPP scaling factor \\
\hline 1 & $\begin{array}{l}1-1 \\
1-2 \\
1-3\end{array}$ & $\begin{array}{l}\text { No. } 1 \text {; i.e.: } \\
\left(\mathrm{WTP}_{\max }, t_{\text {inund }} \text { and } M_{\text {add }}\right)=(0.1,150,+0.05) \\
\text { No. } 2 \text {; i.e.: } \\
\left(\mathrm{WTP}_{\max }, t_{\text {inund }} \text { and } M_{\text {add }}\right)=(0.6,150,+0.1) \\
\text { No. } 3 ; \text { i.e.: } \\
\left(\mathrm{WTP}_{\max }, t_{\text {inund }} \text { and } M_{\text {add }}\right)=(0.2,250,+0.008)\end{array}$ & $\begin{array}{l}\text { not pre- } \\
\text { scribed }\end{array}$ & $\begin{array}{l}\text { fldd }_{\text {product }} \\
\text { fldd }_{\text {product }} \\
\text { fldd }_{\text {redist }}\end{array}$ & no scaling factor \\
\hline 2 & $\begin{array}{l}2-1 \\
2-2 \\
2-3\end{array}$ & $\begin{array}{l}\text { No. } 1 \text {; i.e.: } \\
\left(\mathrm{WTP}_{\max }, t_{\text {inund }} \text { and } M_{\text {add }}\right)=(0.1,150,+0.05) \\
\text { No. } 2 ; \text { i.e.: } \\
\left(\mathrm{WTP}_{\max }, t_{\text {inund }} \text { and } M_{\text {add }}\right)=(0.6,150,+0.1) \\
\text { No. } 3 ; \\
\left(\mathrm{WTP}_{\max }, t_{\text {inund }} \text { and } M_{\text {add }}\right)=(0.2,250,+0.008)\end{array}$ & $\begin{array}{l}\text { not pre- } \\
\text { scribed }\end{array}$ & $\begin{array}{l}\text { prescribed from } \\
\text { observations }\end{array}$ & no scaling factor \\
\hline 3 & $\begin{array}{l}3-1 \\
3-2 \\
3-3\end{array}$ & $\begin{array}{l}\text { No. } 1 \text {; i.e.: } \\
\left(\mathrm{WTP}_{\max }, t_{\text {inund }} \text { and } M_{\text {add }}\right)=(0.1,150,+0.05) \\
\text { No. } 2 ; \\
\left(\mathrm{WTP}_{\max }, t_{\text {inund }} \text { and } M_{\text {add }}\right)=(0.6,150,+0.1) \\
\text { No. } 3 ; \\
\left(\mathrm{WTP}_{\max }, t_{\text {inund }} \text { and } M_{\text {add }}\right)=(0.2,250,+0.008)\end{array}$ & $\begin{array}{l}\text { not pre- } \\
\text { scribed }\end{array}$ & $\begin{array}{l}\text { prescribed from } \\
\text { observations }\end{array}$ & $a_{\mathrm{NPP}}$ \\
\hline 4 & & $\begin{array}{l}\text { Similar as grasses and no additional mortality } \\
\left(\mathrm{WTP}_{\max }, t_{\text {inund }} \text { and } M_{\text {add }}\right)=(10,10,0)\end{array}$ & trees & $\begin{array}{l}\text { prescribed from } \\
\text { observations }\end{array}$ & no scaling factor \\
\hline 5 & & $M_{\mathrm{add}}=1$ & grasses & $\begin{array}{l}\text { prescribed from } \\
\text { observations }\end{array}$ & no scaling factor \\
\hline $\begin{array}{l}\text { Optimal } \\
\text { (see Table 4) }\end{array}$ & & $M_{\mathrm{add}}=1$ & grasses & $\begin{array}{l}\text { prescribed from } \\
\text { observations }\end{array}$ & no scaling factor \\
\hline
\end{tabular}

for $\mathrm{CH}_{4}$ production/transport. The aim is to estimate the $\mathrm{CH}_{4}$ emission sensitivity to (i) the parameterization of stress and mortality for vegetation (whose major effect is on vegetation distribution), (ii) the flooding depth parameterization, (iii) the introduced modifications in the methanogenesis computation (Eq. 5), (iv) uncertainties in LPX-computed NPP as well as (v) macrophyte properties (last column of Table 5).

Each simulation, except simulation 7, uses the same forcing climate data set and spin-up procedure as described in Sect. 2.6.2. Note that each simulation reaches its own equilibrium state after spin-up using its own set of parameters. This strategy differs from Wania et al. (2010), where sensitivities were evaluated after perturbing a common equilibrium state by alternative parameter settings. Our simulation 7 is used to investigate the impact of interannual variation in the wetland extent and thus required a different forcing data set from 1979. While the 1979-2009 climatology of PCR-GLOBWB outputs was used for simulations 1-6 (see Sect. 2.6.2), the year-to-year variability in the floodplain extent given by PCR-GLOBWB was explicitly accounted for to force LPX from 1979 onwards in simulation 7. The modifications implemented in LPX to simulate floodplains (inundation stress, mortality) lead to different ecosystem equilib- riums for floodplain and non-floodplain. The implementation of interannual variation in wetland extent from 1979 in simulation 7 altered these equilibria. However, the introduced perturbation was strongly softened in 1993, that is, when the period of comparison between Simulation 7 and WETCHIMP results started.

The simulation results were compared to estimates of $\mathrm{CH}_{4}$ flux densities representative of large spatial regions. For example, Bartlett et al. (1990) use a total of 284 flux measurements from 42 sampling sites along $\sim 1500 \mathrm{~km}$ of the Amazon River to compute an average $\mathrm{CH}_{4}$ flux density. Average fluxes are usually given for floating grass mats, flooded forest, as well as open water. These measurements are generally similar to those described in "Simulations at individual sites" Section. Table 6 provides an overview of the studies that were used, with the corresponding geographical regions and time periods of the measurements. Smith et al. (2000) give a mean $\mathrm{CH}_{4}$ flux density for a region along the Orinoco River, which is used in Section 4 to discuss the ability of LPX to simulate $\mathrm{CH}_{4}$ flux densities outside of the Amazon Basin. To allow a comparison of LPX results to upscaling estimates, separate emissions from flooded forest and flooded grasses were required from LPX. However, because in LPX, 
Table 4. Description of the "optimal" simulation for each site. For each site, the "optimal" simulation has to be compared to the site's simulation no. 5 (Table 3). According to Wania et al. (2010), the root profile is defined by $C_{\text {root }} e^{z / \lambda_{\text {root }}}$, where $C_{\text {root }}$ is a normalization constant to give a total root biomass of $100 \%$ within $2 \mathrm{~m}$ depth. Optimal simulation for sites 1 and 2 corresponds to a modification of the $\lambda$ root value.

\begin{tabular}{ll}
\hline Site & "Optimal" simulation \\
\hline 1 - Cuini & Less deep root profile $\left(\lambda_{\text {root }}=3.2 \mathrm{~cm}\right)$ and increase \\
& in soil porosity (to peatland soil porosity) \\
2 - Itu & Deeper root profile $\left(\lambda_{\text {root }}=85 \mathrm{~cm}\right)$ \\
3 - Araca & No simulation \\
4 - Isla Marchantaria & Tiller porosity $=0$ and no exudates for flood-tolerant $\mathrm{C}_{4}$ \\
5 - Marrecao/Pesqueiro/Cabaliana & Tiller porosity $=0$ and no exudates for flood-tolerant $\mathrm{C}_{4}$ \\
Supp. Site 1 - Lago Colado & No simulation \\
Supp. Site 2 - Spot in Pantanal wetland & Tiller porosity $=0$ and no exudates for flood-tolerant $\mathrm{C}_{4}$ \\
Supp. Site $3-$ Spot in Panama & No simulation \\
\hline
\end{tabular}

Table 5. Set-up for simulations at Amazon Basin scale.

\begin{tabular}{|c|c|c|c|c|c|c|}
\hline $\begin{array}{l}\text { Simu- } \\
\text { lation } \\
\text { number }\end{array}$ & $\begin{array}{l}\text { Flood } \\
\text { depth }\end{array}$ & $\begin{array}{l}\text { Parameters combination for } \\
\text { flood-tolerant trees no. } \\
\text { (numbers refer to Table 1) }\end{array}$ & $\begin{array}{l}\text { NPP } \\
\text { scaling } \\
\text { factor }\end{array}$ & $\begin{array}{l}\text { Modification } \\
\text { of production } \\
\text { or transport }\end{array}$ & $\begin{array}{l}\text { IAV of } \\
\text { flood- } \\
\text { plain } \\
\text { extent }\end{array}$ & $\begin{array}{l}\text { Estimated } \mathrm{CH}_{4} \text { emissions } \\
\text { sensitivity to... (when } \\
\text { compared to reference } \\
\text { simulation) }\end{array}$ \\
\hline 1 & fldd $_{\text {product }}$ & $\begin{array}{l}\text { No. } 1 \text { i.e., }\left(\mathrm{WTP}_{\max }, t_{\text {inund }} \text { and } M_{\text {add }}\right) \\
=(0.1,150,+0.05)\end{array}$ & no & no & no & reference \\
\hline 2 & fldd $_{\text {product }}$ & $\begin{array}{l}\text { No. } 2 \text { i.e., }\left(\mathrm{WTP}_{\max }, t_{\text {inund }} \text { and } M_{\text {add }}\right) \\
=(0.6,150,+0.1)\end{array}$ & no & no & no & $\begin{array}{l}\text { to vegetation distribution } \\
\text { (resulting from difference } \\
\text { in parameter values of } \\
\text { stress and trees mortality) }\end{array}$ \\
\hline 3 & fldd $_{\text {redist }}$ & $\begin{array}{l}\text { No. } 3 \text { i.e., }\left(\mathrm{WTP}_{\max }, t_{\text {inund }} \text { and } M_{\text {add }}\right) \\
=(0.1,150,+0.05)\end{array}$ & no & no & no & $\begin{array}{l}\text { to the way to account for } \\
\text { flood depth }\end{array}$ \\
\hline 4 & fldd $_{\text {product }}$ & No. 1 & $a_{\mathrm{NPP}}$ & no & no & $\begin{array}{l}\text { to NPP correction according } \\
\text { to the MODIS-derived } \\
\text { non-floodplain NPP }\end{array}$ \\
\hline 5 & fldd $_{\text {product }}$ & No. 1 & no & $\begin{array}{l}\text { remove the introduced } \\
\text { decrease in production } \\
\text { when } \mathrm{O}_{2} \text { (Eq. 5) }\end{array}$ & no & $\begin{array}{l}\text { to production para- } \\
\text { meterization }\end{array}$ \\
\hline 6 & fldd $_{\text {product }}$ & No. 1 & no & $\begin{array}{l}\text { tiller porosity equal } \\
\text { to } 0 \text { and no exudates for } \\
\text { flood-tolerant grasses }\end{array}$ & no & $\begin{array}{l}\text { to floating macrophytes } \\
\text { characteristics }\end{array}$ \\
\hline 7 & fldd $_{\text {product }}$ & No. 1 & no & no & yes & $\begin{array}{l}\text { to the accounting for IAV } \\
\text { in floodplain extent }\end{array}$ \\
\hline
\end{tabular}

$\mathrm{CH}_{4}$ flux densities are computed for the entire floodplain LU without distinguishing among PFTs, we classified each grid cell as a "flooded forest" or "flooded grasses" ecosystem using four different criteria (details in Appendix A). In each case, only grid cells where floodplain cover was greater than $5 \%$ of the grid cell were retained.

Finally, the floodplain $\mathrm{CH}_{4}$ emissions were compared to the outputs of the models participating in the WETCHIMP intercomparison (Melton et al., 2013; Wania et al., 2013). WETCHIMP (Wetland and Wetland $\mathrm{CH}_{4}$ Intercomparison of Models Project) was organized to evaluate our present ability to simulate large-scale wetland characteristics and corresponding $\mathrm{CH}_{4}$ emissions. In the present study, we use emission estimates for the Amazon Basin from six WETCHIMP models (see right panel of Table 7). An overview of the computation in the WETCHIMP models of the two components that determine total $\mathrm{CH}_{4}$ emissions (i.e., the $\mathrm{CH}_{4}$ flux densities and the wetland extent) were given in Figs. 7 and 8 of Wania et al. (2013). Briefly, none of the WETCHIMP models distinctly accounted for floodplain extents. Few models use a hydrological model to estimate the extents of locally saturated wetland (e.g., SDGVM; Hopcroft et al., 2011), while some other models represented all wetland types by relying on the Papa et al. (2010) data set (e.g., CLM4Me; Riley et al., 2011). No models had been specifically designed for tropical wetland ecosystems and had floodplain PFTs. The comparison between the current LPX model and the WETCHIMP models focuses on the magnitude of emissions 
Table 6. Available information about $\mathrm{CH}_{4}$ flux density at large scale. Geographical areas selected to estimate comparable LPX-computed $\mathrm{CH}_{4}$ flux densities are given in the last column. Areas 1 and 2 are in the Amazon Basin, while the last area (Supp. Site 1) is located in the Orinoco Basin. Despite some differences in the spots used to estimate the mean $\mathrm{CH}_{4}$ flux density, we consider that Devol et al. (1988), Bartlett et al. (1990) and Devol et al. (1990) give information about the same geographical area.

\begin{tabular}{|c|c|c|c|c|}
\hline $\begin{array}{l}\text { Area } \\
\text { number }\end{array}$ & Reference & Area of measurements & Period of measurements & $\begin{array}{l}\text { Area used in LPX to compute } \\
\text { the mean } \mathrm{CH}_{4} \text { flux density }\end{array}$ \\
\hline \multirow[t]{3}{*}{1} & $\begin{array}{l}\text { Devol et al. (1988) } \\
\text { (corrected by Bartlett } \\
\text { et al., 1990) }\end{array}$ & $\begin{array}{l}\text { "fringing" floodplains } \\
\text { along 1700 km of the } \\
\text { Amazon River main } \\
\text { stem; between "Vargem } \\
\text { Grande" and Obidos }\end{array}$ & $\begin{array}{l}\text { Jul-Aug } 1985 \text { (early falling } \\
\text { water period of the flood } \\
\text { cycle) }\end{array}$ & $\begin{array}{l}\text { quadrate defined by: } \\
\text { latitude: }\left[5^{\circ} \mathrm{S}: 1.5^{\circ} \mathrm{S}\right] \\
\text { longitude: }\left[70^{\circ} \mathrm{W}: 55^{\circ} \mathrm{W}\right]\end{array}$ \\
\hline & Bartlett et al. (1990) & & $\begin{array}{l}\text { Apr-May } 1987 \text { (wet season } \\
\text { as river water levels were } \\
\text { high and rising) }\end{array}$ & $\begin{array}{l}\text { quadrate defined by: } \\
\text { latitude: }\left[5^{\circ} \mathrm{S}: 1.5^{\circ} \mathrm{S}\right] \\
\text { longitude: }\left[70^{\circ} \mathrm{W}: 55^{\circ} \mathrm{W}\right]\end{array}$ \\
\hline & Devol et al. (1990) & & $\begin{array}{l}\text { Nov-Dec } 1988 \text { (low water } \\
\text { period of the annual flood } \\
\text { cycle) }\end{array}$ & $\begin{array}{l}\text { quadrate defined by: } \\
\text { latitude: }\left[5^{\circ} \mathrm{S}: 1.5^{\circ} \mathrm{S}\right] \\
\text { longitude: }\left[70^{\circ} \mathrm{W}: 55^{\circ} \mathrm{W}\right]\end{array}$ \\
\hline 2 & & $\begin{array}{l}\text { eight lakes near Manaus } \\
\left(03^{\circ} 06^{\prime} \mathrm{S} ; 60^{\circ} 01^{\prime} \mathrm{W}\right)\end{array}$ & May 1987-Sep 1988 & $\begin{array}{l}\text { quadrate defined by: } \\
\text { latitude: }\left[3.5^{\circ} \mathrm{S}: 2.5^{\circ} \mathrm{S}\right] \\
\text { longitude: }\left[60.5^{\circ} \mathrm{W}: 59.5^{\circ} \mathrm{W}\right]\end{array}$ \\
\hline $\begin{array}{l}\text { Supp. } \\
\text { Area } 1\end{array}$ & Smith et al. (2000) & $\begin{array}{l}\text { "fringing" floodplains } \\
\text { along a } 600 \mathrm{~km} \text {-reach of } \\
\text { the Orinoco main stem } \\
\text { and the upper delta }\end{array}$ & Jul 1991-Sep 1992 & $\begin{array}{l}\text { quadrate defined by: } \\
\text { latitude: }\left[7^{\circ} \mathrm{N}: 10^{\circ} \mathrm{N}\right] \\
\text { longitude: }\left[66^{\circ} \mathrm{W}: 60.5^{\circ} \mathrm{W}\right]\end{array}$ \\
\hline
\end{tabular}

in the Amazon Basin, the spatial distribution as well as the temporal variability (both the seasonal and year-to-year variability) of the two above-cited $\mathrm{CH}_{4}$ emissions components. Given the uncertainty in the Amazon floodplain extent and the high estimates thereof by PCR-GLOBWB, as compared to GLC2000 (see Sect. 3.1), the emission sensitivity to floodplain extent was evaluated. To do so, we only retained grid cells where the GLC2000 flooded vegetation fraction was larger than $2 \%$. For these grid cells, PCR-GLOBWB outputs were used to provide both floodplain extent and flooding depth.

\section{Results}

\subsection{Floodplain extents}

Around $6.8 \%$ of South America is covered by floodplain according to PCR-GLOBWB, against only $3.7 \%$ in GLC2000 (Fig. 1). Outside of the Amazon Basin, GLC2000 and PCRGLOBWB agree relatively well, such as for floodplains in the Pantanal and along the Parana River. However, the largest differences are found within the Amazon Basin, in particular in the south of the basin and along the Amazon River itself: 4.1 and $12.2 \%$ of the Amazon Basin are covered by floodplains for GLC2000 and PCR-GLOBW, respectively. If only grid cells where the GLC2000 flooded vegetation frac- tion is larger than $2 \%$ are retained, $\mathrm{fldf}_{\text {mean }}$ reaches $6.7 \%$, in other words, a value much closer to the GLC2000 estimates. This means that the mismatch between PCR-GLOBWB and GLC2000 at $0.5^{\circ}$ resolution is mainly explained by the presence of additional (small) floodplains in PCR-GLOBWB, instead of a large disagreement in the extent of floodplains that are accounted for in both estimates.

This difference may be explained in part by the fact that fldf $_{\text {mean }}$ is only based on hydrological processes, whereas GLC2000 represents land fractions where the floodplain vegetation is dominant. fldf $_{\text {mean }}$ might be interpreted as the potentially vegetated floodplain extent, of which the actual occurring floodplains given by GLC2000 is a subset. In addition, some wetlands are difficult to observe by remote sensing (Miguez-Macho and Fan, 2012). For instance, the western reach of the Solimoes/Amazon main stem floodplain has a considerably greater proportion of flooded forest than the eastern reach (Melack et al., 2004), while this is not apparent in GLC2000. The difficulty in estimating flooded area under forest canopies suggests that floodplain extent in the west of the basin may be underestimated in GLC2000. The true floodplain extent of the Amazon Basin is, however, poorly known: Junk et al. (2011) indicate that about $30 \%$ of the 7 million $\mathrm{km}^{2}$ comply with international criteria for wetland definition, while Melack and Hess (2010) give an estimate of $14 \%$ of the lowland Amazon Basin $(<500 \mathrm{~m})$. 
Table 7. LPX-simulated floodplain $\mathrm{CH}_{4}$ emissions at Amazon Basin scale (averaged over 1993-2004) and comparison to the WETCHIMP models. The used Bern-LPJ estimates do not account for wet mineral soils (see Wania et al., 2013). LPX estimates are given with (left) and without (right) filtering using GLC2000 (see Sect. 2.5.2).

\begin{tabular}{|c|c|c|c|c|c|}
\hline & \multicolumn{2}{|c|}{ LPX $\left(\mathrm{Tg} \mathrm{yr}^{-1}\right)$} & \multirow[b]{2}{*}{$\begin{array}{l}\text { WETCHIMP } \\
\text { model }\end{array}$} & \multirow[b]{2}{*}{$\begin{array}{r}\text { Amazon } \\
\text { Basin } \\
\text { emissions } \\
\left(\mathrm{Tg} \mathrm{yr}^{-1}\right)\end{array}$} & \multirow[b]{2}{*}{$\begin{array}{l}\text { Amazor } \\
\text { contribution t } \\
\text { total emission } \\
(\%\end{array}$} \\
\hline & $\begin{array}{r}\text { Without } \\
\text { any } \\
\text { mask }\end{array}$ & $\begin{array}{r}\text { With mask } \\
\text { from } \\
\text { GLC2000 }\end{array}$ & & & \\
\hline Simul. 1 & 88.4 & 43.2 & Bern-LPJ & 8.2 & 8.8 \\
\hline Simul. 2 & 106.3 & 51.9 & DLEM & 8.8 & 6.2 \\
\hline Simul. 3 & 85.2 & 43.9 & SDGVM & 59.8 & 30.1 \\
\hline Simul. 4 & 78.4 & 36.9 & WSL & 20.5 & 11.8 \\
\hline Simul. 5 & 88.5 & 43.2 & ORCHIDEE & 59 & 22.3 \\
\hline Simul. 6 & 87.8 & 42.7 & CLM4Me & 55.1 & 26.7 \\
\hline Simul. 7 & 94.2 & 49.1 & & & \\
\hline Mean & 89.1 & 44.4 & & & \\
\hline Std & 9.3 & 4.8 & & & \\
\hline
\end{tabular}

From a model point of view, the realism from simulated floodplain extent could be doubted by different model limitations. First, the parameters used as the dimensions of the river bed, its resistance and that of the inundated floodplain (Manning's coefficient respectively set here to uniform values of 0.04 and 0.10 ) are relatively uncertain. Anthropogenic effects are not accounted for. While the model includes the effect of additional resistance on water depths and travel times from floodplain extent, it does this as part of the channel flow. Thus, delay introduced by the flooding and draining of the inundated area is only partially accounted for. Moreover, processes such as the increased evaporation under flooded forest and the losses due to infiltration are neglected, although they may become perceptible over the large flooded areas of the Amazon Basin. Nevertheless, the inclusion of the floodplain in the PCR-GLOBWB simulations results in a more realistic hydrograph for the Amazon River (Fig. A5).

To test the influence of the differences in the PCRGLOBWB- and GLC2000-estimated floodplain extents, we estimated floodplain $\mathrm{CH}_{4}$ emissions using PCR-GLOBWB outputs with and without filtering for grid cells that contain floodplains in GLC2000 (as described in Sect. 2.5.2).

\subsection{Floodplain vegetation}

\subsubsection{Trees/grasses contribution to total vegetation cover}

Overall, GLC2000 shows a larger grass contribution to the total vegetation cover in floodplain ecosystems $(y)$ than in non-floodplain ecosystems ( $x$ ) (Fig. $2 ; y / x$ ratio $\gg 1$ ). The exception to this pattern is Llaonos de Mojos, which is characterized by a much smaller difference in vegetation between floodplains and non-floodplains $(y / x=1.8)$ compared to the rest of the Amazon $(y / x=14.1)$. Llaonos de Mojos is a trop- ical savanna in the Bolivian Amazon, characterized by a large human impact and specific meteorological conditions with a larger seasonal cycle in precipitation (Walker, 2008). The distinct vegetation cover of Llaonos de Mojos is not represented by LPX.

In LPX, trees dominate over grasses in non-floodplain ecosystems. The fractional tree cover is limited to a maximum coverage of $95 \%$ in each LU (see Sect. 2.1). At this maximum, grasses can only occupy the remaining $5 \%$; a situation that is simulated in the non-floodplain LU of most grid cells (see Fig. 2; dots on the $x=0.05$ line). The floodplain $\mathrm{LU}$ was modeled to decrease tree growth, facilitating the competition of grasses $(y / x \gg 1)$. Consequently, the grass contribution to total vegetation is much larger for the floodplain than the non-floodplain LU and ranges typically between 20 and $80 \%$. The use of $M_{\text {add }}$ (additional mortality for flood-tolerant trees on floodplain LU, see Sect. 2.3.3) as a tuning parameter allows us to bring the mean $y / x$ ratio of LPX in agreement with GLC2000 for the Amazon Basin (after excluding Llaonos de Mojos).

Different parameter settings, even if reproducing the same $y / x$ ratio averaged at Amazon Basin scale, lead to very different spatial patterns at smaller scales. These differences are particularly clear when comparing the parameterizations using fldd redist $_{\text {and fldd }}$ product, respectively. Using fldd $_{\text {redist }}$, the floodplain LU is either entirely covered by trees or by grasses, whereas for fldd $_{\text {product }}$, mixed conditions are more common. This is related to the influence of the choice of fldd on productivity, affecting the inundation stress distribution (Fig. A6).

\subsubsection{NPP}

Figure 3 compares the LPX-simulated NPP with the MODISderived NPP for non-floodplain (top panel) and floodplain 


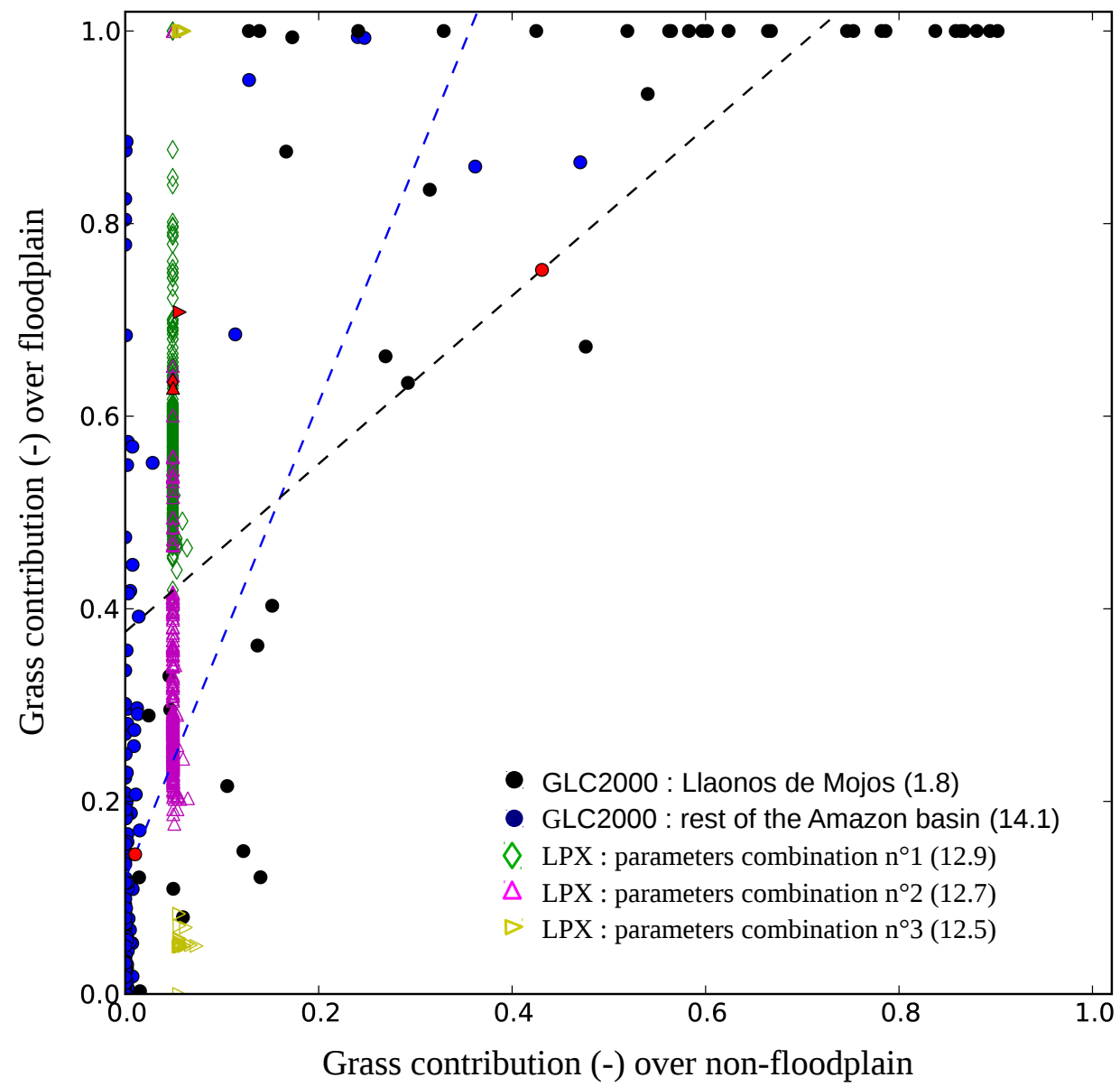

Fig. 2. Effect of flooded conditions on the contribution of grasses to total vegetation cover. Each $0.5^{\circ}$ resolution grid cell in the Amazon Basin whose floodplain and non-floodplain extents are both larger than $10 \%$ of the total grid cell area is considered. Each dot corresponds to a grid cell and is defined by the grass contribution to the total vegetation cover over non-floodplain ( $x$ value) and floodplain grid-cell fraction ( $y$ value). The vegetation cover for both LPX and GLC2000 data sets are plotted. For LPX, the different vegetation covers are approximated by the sum of FPC over all PFTs corresponding to this vegetation cover. A mean ratio $y / x$ is given for each estimate (in brackets in the legend) and its corresponding symbol is displayed in red. Two distinct regions of the Amazon Basin (Llaonos de Mojos in blue; rest of the Amazon Basin in black) are identified in the GLC2000 data sets. The vegetation covers simulated by three LPX simulations, which differ through the used (fldd, $t_{\text {inund }}, \mathrm{WTP}_{\max }, M_{\text {add }}$ ) set of parameters (see Table 1), are plotted.

(bottom) ecosystems. It shows the improved agreement between LPX and MODIS on both LUs when the $a_{\text {NPP }}$ scaling factor is applied. The improvement for the non-floodplain is trivial since $a_{\mathrm{NPP}}$ was calibrated using non-floodplain ecosystems. A significant deviation from the $1: 1$ line in Fig. $3 \mathrm{~b}$ remains: the slope of the regression after forcing it to have an intercept equal to 0 is 1.015 (std error: 0.003 , paired $t$ test $<0.05$ ). This is explained by the fact that $a_{\mathrm{NPP}}$ was computed from the last 10 years of the simulation plotted in Fig. 3a and then applied to the whole simulation (including spin-up) plotted in Fig. 3b (cf. Sect. 2.3.5). The application of $a_{\mathrm{NPP}}$ to the floodplain LU improves the agreement in floodplain NPP between MODIS and LPX: the slope of the MODIS vs. LPX linear regression increases from -0.08 in Fig. 3c to 0.51 in panel 3d, with a $R^{2}$ of 0.016 and 0.42 , re- spectively. However, a mismatch in floodplain NPP between MODIS and LPX remains: slopes of regression after forcing it to have an intercept equal to 0 are $0.782,0.901,0.966$ and are significantly different to 1 (paired $t$ test $<0.05$ ). This could not be attributed to LPX shortcomings in accounting for processes relevant to both ecosystems (e.g., phosphorus limitation).

After applying $a_{\mathrm{NPP}}$, we evaluated the effect of flooding conditions on NPP by comparing, for each grid cell, floodplain and non-floodplain NPP for both MODIS-GLC2000 and LPX (Fig. 4). Floodplain conditions have effects on (i) vegetation cover (contribution of grass vs. trees, see Sect. 3.2.1) and (ii) NPP for each vegetation type, both contributing to differences in total NPP (i.e., without vegetation type distinction) between floodplain and non-floodplain 


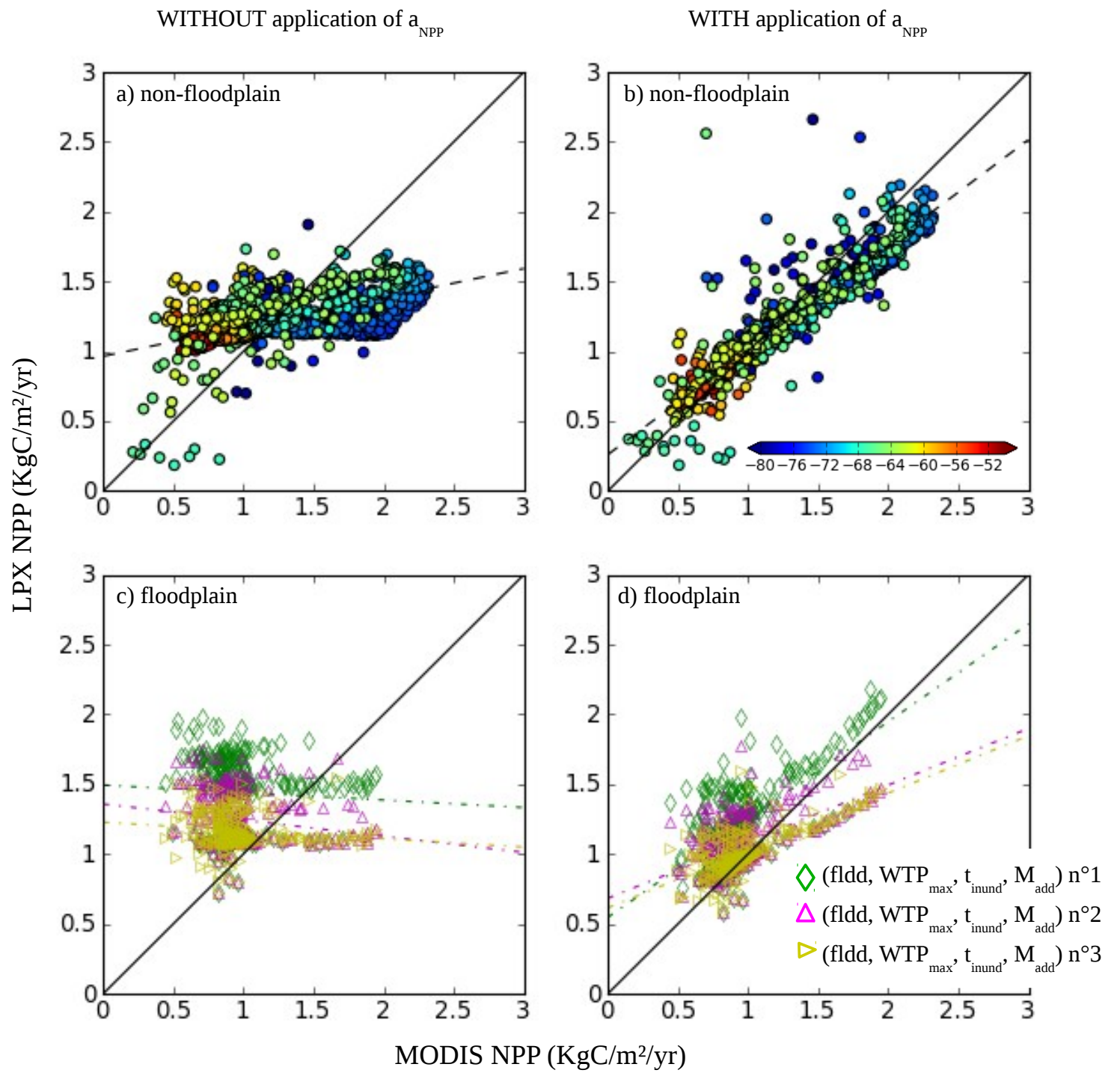

Fig. 3. LPX-simulated NPP vs. MODIS-derived NPP for non-floodplain (top line, $\mathbf{a}$ and $\mathbf{b}$ ) and floodplain ecosystems (bottom line, $\mathbf{c}$ and $\mathbf{d}$ ). The MODIS vs. LPX relationship is given without (left panels, $\mathbf{a}$ and $\mathbf{c}$ ) and with (right panels, $\mathbf{b}$ and $\mathbf{d}$ ) application of the $a_{\mathrm{NPP}}$ scaling factor. $a_{\text {NPP }}$ was calibrated on non-floodplain ecosystems, which explains why the inclusion of $a_{\mathrm{NPP}}$ is characterized by a strong improvement (a: slope of 0.21 and $R^{2}$ of 0.31 ; b: slope of 0.75 with a $R^{2}$ of 0.85 ). For each panel, a dot corresponds to a grid cell where the considered ecosystem occupies more than $5.1 \%$ of the grid cell in both GLC2000 and LPX. The color pallet corresponds to the longitudinal localization (in ${ }^{\circ} \mathrm{W}$ ) of each grid cell. Results of three LPX simulations varying through the used fldd and the tree parameterizations (cf. Table 1) are plotted in the bottom panels.

ecosystems. In LPX, the differences in vegetation cover drive the difference in total NPP between simulations 1 and 3 (see the larger difference in Fig. 4d than in either Fig. 4e or f). This difference in vegetation cover results from differences in flood tolerance settings (Fig. A7). To test the significance of non-flooded vs. flooded NPP in both MODIS and LPX, we forced linear regressions to have an intercept equal to 0 (called hereafter FLR). Results of the significance test are summarized in Table A2.

In MODIS-GLC2000, the flooding conditions have only a very weak effect on the NPP of trees (Fig. 4b, Table A2: slope of FLR not significantly different from 1). In contrast, grasses show a decrease in NPP of $11 \%$ on average (Fig. 4c; Table A2: paired $t$ test $<0.05$ ). In agreement with MODISGLC2000, the floodplain and non-floodplain ecosystems in LPX show almost no difference in the simulated NPP of trees (Fig. 4e): while significantly different from 1 (paired $t$ test in Table A2 <0.05), the computed FLR slopes are very close to $1(0.898,0.936$ and 0.949 for the LPX simulations with different parameter combinations). Despite the introduction of some stress, LPX tries to optimize ecosystems' productivity given the available resources (light, water, temperature, 
$\mathrm{CO}_{2}$, nutrients, etc.). As in MODIS, grasses show a larger difference between floodplain and non-floodplain NPP. However, the sign is opposite: in LPX, the effect of flooding is to increase the NPP (Fig. 4f; Table A2: slopes of FLR significantly lower than 1).

The high productivity of flooded grasses in LPX displayed in Fig. $4 \mathrm{f}$ is explained by $\mathrm{WTP}_{\max }$ and $t_{\text {inund }}$ of grass floodtolerant PFTs. Because of the short $t_{\text {inund }}$, the flood-related stress for grasses tends to be either 0 or 1 . In the latter case, no grasses are present at all and by default, those grid cells are not represented on Fig. 4e. For those grid cells where a significant grass cover is simulated, their inundation stress is close to 0 and saturated conditions lead to enhanced NPP. The NPP characteristics found by MODIS-GLC2000 are not confirmed by field studies: a reduced metabolism is observed in flooded conditions for some tree species (e.g., Wittmann et al., 2006), while flooded grasses may be very productive (Engle et al., 2007; Piedade et al., 1991). As the relation from MODIS is not confirmed, it seems premature to adjust the $\mathrm{WTP}_{\max }$ and $t_{\text {inund }}$ parameters in LPX to better reproduce the MODIS-derived NPP of grasses.

\subsection{Floodplain $\mathrm{CH}_{4}$ emissions}

\subsubsection{On-site evaluation of $\mathrm{CH}_{4}$ flux density}

The evaluation of $\mathrm{LPX} \mathrm{CH}_{4}$ emissions with site data is hampered by the scarcity of available measurements as well as by the mismatch between the spatial coverage of such measurements and the spatial resolution of Land Surface Models. Figure 5 displays a comparison between the $\mathrm{CH}_{4}$ flux densities simulated by LPX and measurements at Cuini, Itu and Araca (sites 1-3) where information is available at a yearly timescale. For sites 4 (Isla Marchentaria) and 5 (Marrecao), information is available at a monthly timescale (Fig. 6). In the following, the two groups of sites are treated separately. Regarding LPX, we rely on a set of sensitivity simulations with different parameter settings and vegetation cover (Table 3).

Sites 1-3 concern interfluvial wetlands in the Negro River basin. We determined the total measured flux at each site by summing up the ebullition and diffusive fluxes. A mean diffusive flux for different types of vegetation was computed by weighting grasses and non-grass vegetation (i.e., shrub, forest and palms) equally. For ebullition, the measurements do not distinguish between different vegetation types. Mean annual $\mathrm{CH}_{4}$ flux densities of $294.8 \pm 56.5,28.4 \pm 130.6$ and $29.4 \pm 12.6 \mathrm{mg} \mathrm{CH}_{4} \mathrm{~m}^{2} \mathrm{~d}^{-1}$ were observed for Cuini, Itu and Araca, respectively. Annual $\mathrm{CH}_{4}$ flux densities simulated by LPX (mean over the simulation settings 4 and 5) are 307.0, 308.0 and $310.3 \mathrm{mg} \mathrm{CH}_{4} \mathrm{~m}^{2} \mathrm{~d}^{-1}$ for each site, respectively. Thus, LPX captures the total flux at Cuini rather well, but overestimates it at Itu. The evaluation of LPX performance at Araca is difficult since no information about ebullition is available.
Total emissions range between 257 and $361 \mathrm{mg} \mathrm{CH}_{4} \mathrm{~m}^{2} \mathrm{~d}^{-1}$ at Cuini and between 296 and $386 \mathrm{mg} \mathrm{CH}_{4} \mathrm{~m}^{2} \mathrm{~d}^{-1}$ at Itu for the different LPX sensitivity simulations (Fig. 5, Table 3). The difference between simulations 1 and 2 indicates the sensitivity of $\mathrm{CH}_{4}$ flux densities to the use of regional PCR-GLOBWB hydrology instead of local information. Prescribed WTD leads to larger $\mathrm{CH}_{4}$ emissions than the use of PCR-GLOBWB (three sites' average of $388.0 \pm 22.9$ vs. $333.1 \pm 14.0$ ). This is partly explained by WTD-induced changes in vegetation (cf. pie charts in Fig. 4). In LPX, the total emissions are on average lower when grasses (mean of simulation four over the three sites: $266.0 \pm 11.8$ ) than when trees dominate vegetation cover (mean of simulation 5 over the three sites: $350.9 \pm 14.5$ ). Prescribing the reported local vegetation leads to slightly higher emissions than using simulated vegetation (simulation 2 vs. either 4 or 5). The total flux is reduced by about $10 \%$ for the first three sites when the $a_{\text {NPP }}$ scaling factor is applied. Finally, prescribing the local conditions for sites 1 and 2 ("optim" simulation) does not improve the agreement between LPX and observations (e.g., the observed lower ebullition at Itu).

While total emissions vary within a relatively confined range, the contribution of individual transport pathways to the total emissions can be very different for these different model set-ups and parameter choices. For example, plantmediated transport is preferred over ebullition in the case of extensive grass cover (simulations 4 vs. 5). Belger et al. (2010) assume that measured diffusive fluxes include plant-mediated transport. Because of the larger difference between vegetated and non-vegetated spots in Itu than in Cuini, they concluded that plant-mediated transport is absent at Cuini. If the LPX-derived plant-mediated transport and diffusion are combined, a good agreement with the measured diffusive fluxes is obtained at Cuini when tree cover is prescribed. However, grass cover leads to a large overestimation of the combined diffusive component. This overestimation seems to be more relevant than the agreement found when prescribing trees, because the site description (Table 2) only mentions shrubs and no trees. At Itu, the overestimated ebullition cannot be evaluated with respect to the other transports pathways, in absence of vegetation specific ebullition measurements.

Figure 6 displays a comparison at monthly timescale between LPX-simulated $\mathrm{CH}_{4}$ flux densities and observations for Isla Marchentaria (site 4; Wassmann et al., 1992) and Marrecao (site 5; Bartlett et al., 1988). In the following, we give LPX estimates that represent means over the months for which measurements are available. Overall, the net $\mathrm{CH}_{4}$ flux densities are captured reasonably well for forests (LPX: 233.7 vs. observations: $192 \pm 26.8 \mathrm{mg} \mathrm{CH}_{4} \mathrm{~m}^{2} \mathrm{~d}^{-1}$ ) and grasses (LPX: 209.9 vs. observations: $230 \pm 72.2 \mathrm{mg} \mathrm{CH}_{4} \mathrm{~m}^{2} \mathrm{~d}^{-1}$ ) at site 5. For site 4, LPX-simulated $\mathrm{CH}_{4}$ flux densities are on average overestimated for grasses (LPX: 200.5 vs. observations: 
No vegetation distinction

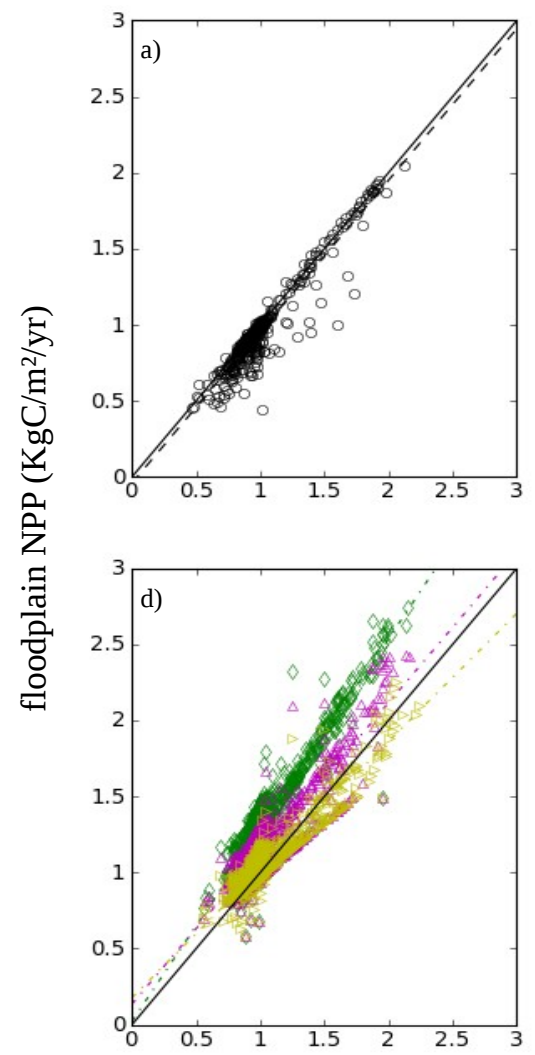

Trees
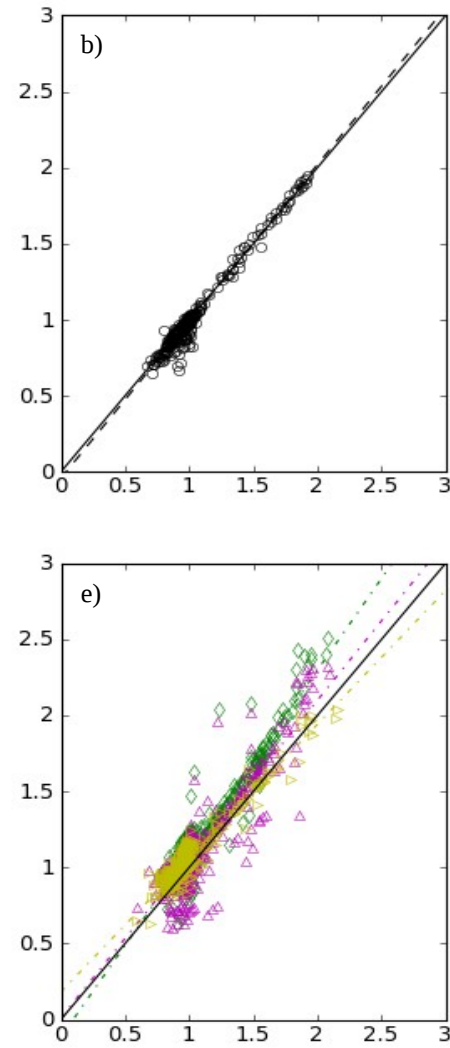

Grasses
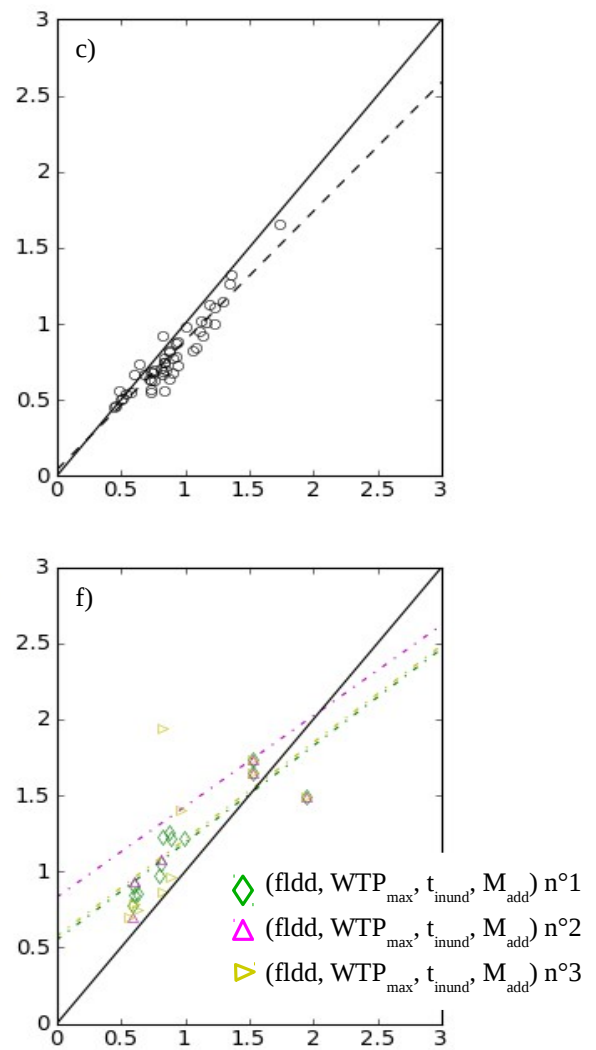

non-floodplain NPP $\left(\mathrm{KgC} / \mathrm{m}^{2} / \mathrm{yr}\right)$

Fig. 4. Effect of flooded conditions on NPP for different vegetation types (left, middle and right columns for no vegetation distinction, trees and grasses, respectively) for both MODIS/GLC2000 (top panels) and LPX in case of application of $a_{\mathrm{NPP}}$ (bottom panels). Each dot corresponds to a grid cell where the considered ecosystem occupies more than $5.1 \%$ of the grid cell for both floodplain and non-floodplain. As for Fig. 3, results of three LPX simulations varying through the used fldd and the tree parameterizations are given in the bottom panels. The reader should also report to Fig. A6 where the scatterplot corresponding to (e) is given separately for LPX simulations 1 and 2.

$35.3 \pm 4.8 \mathrm{mg} \mathrm{CH}_{4} \mathrm{~m}^{2} \mathrm{~d}^{-1}$ ) and trees (LPX: 229.5 vs. observations: $76.7 \pm 8.6 \mathrm{mg} \mathrm{CH}_{4} \mathrm{~m}^{2} \mathrm{~d}^{-1}$ ). Increased $\mathrm{CH}_{4}$ flux densities are temporarily observed over forests (e.g., 200 $\mathrm{mgCH}_{4} \cdot \mathrm{m}^{2} \cdot \mathrm{d}^{-1}$ in August) and for these particular time periods, observations and LPX are in agreement. Indeed, a large seasonality in $\mathrm{CH}_{4}$ flux density in forests is observed at site 4 and is characterized by high fluxes during high water levels (May-July) and low fluxes during rising water levels (FebApr). According to Wassmann et al. (1992), these low fluxes are caused by increased oxygen concentrations in the water column due to entrainment of oxygen-rich river water into the floodplain. Such lateral and small-scale water fluxes are not accounted for in the model and could explain the underestimated seasonality in LPX-simulated $\mathrm{CH}_{4}$ flux densities.

At site 5, there is no significant difference in the observed total flux density between tree- and grass-covered areas. This is not the case for site 4, where flux densities in tree-covered areas (averaged over the measurement period) are about two times the flux over grasses. For both sites, LPX reproduces a slightly larger flux over trees than over grasses, but the size of the difference $(\sim+12.6$ and $+10.2 \%$, respectively, for site 4 and 5) is almost insignificant.

At site 4, the measured contribution of different transport pathways to total emissions are similar for tree- and grasscovered areas and vary seasonally. A predominantly diffusive contribution is observed during rising water tables (up to $82.8 \%$ of total flux in forest during the period FebruaryApril) while ebullition dominates during high water levels (up to $96.3 \%$ of total flux in forest during the period MayAugust). Because of floating macrophytes, plant-mediated transport is assumed to be absent at site 4 (Wassmann et al., 1992). Site 5 shows a larger contribution of diffusion for grasses than for trees. As for site 4, "grasses" mainly include floating macrophytes (Bartlett et al., 1988). LPXsimulated $\mathrm{CH}_{4}$ flux densities are characterized by a predominance of plant-mediated transport when grasses are present and of ebullition in the presence of trees at both sites 4 and 5. In both cases, the contribution of diffusion to total flux 

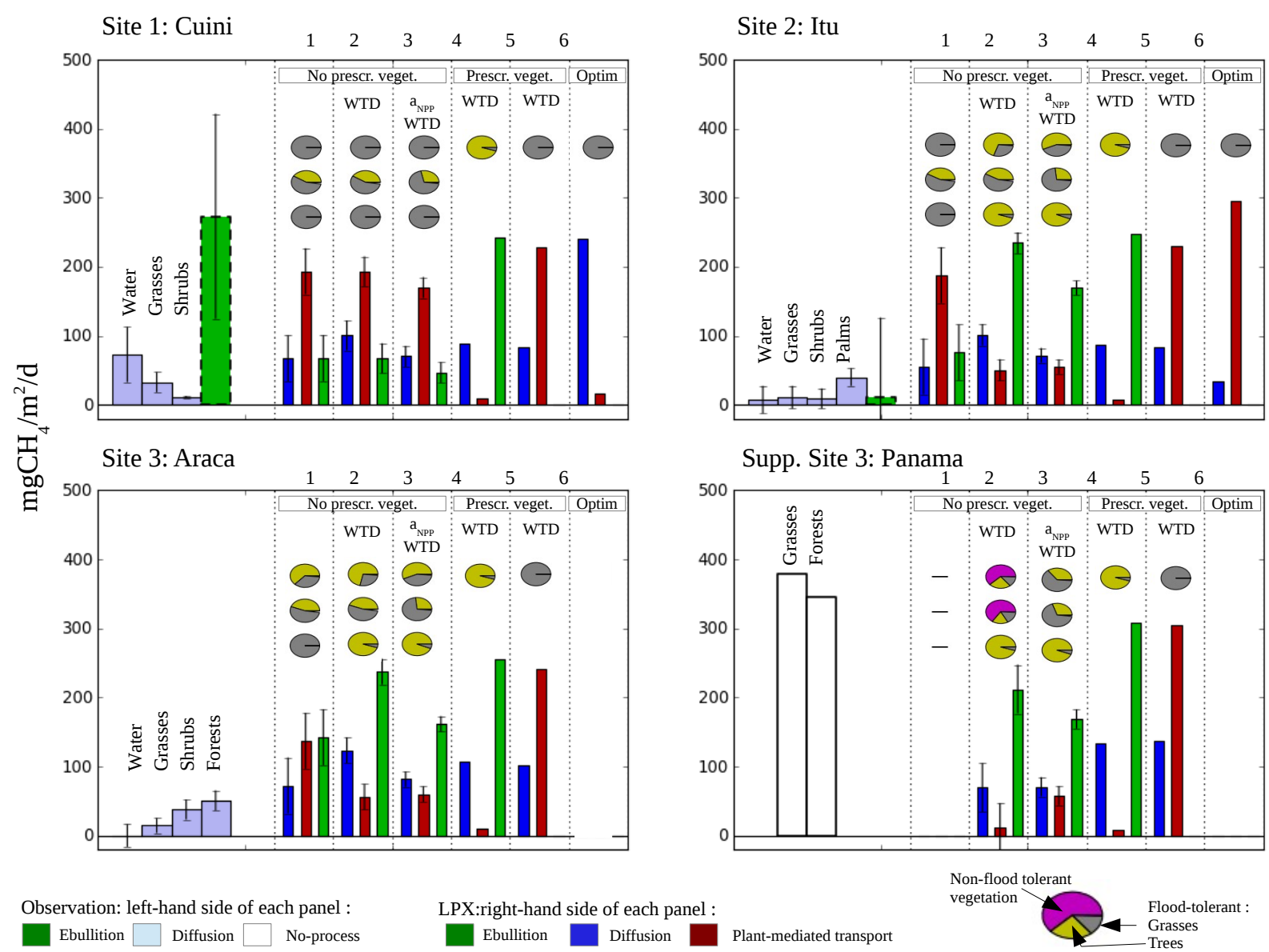

Observation: left-hand side of each panel :

$\square$ Ebullition $\square$ Diffusion $\square$ No-process

LPX:right-hand side of each panel

Ebullition Diffusion

Plant-mediated transport

Fig. 5. Comparison of mean annual $\mathrm{CH}_{4}$ flux densities between LPX-simulations and observations at sites 1, 2, 3 and Supp. Site 3. For these sites, information about mean annual flux density is available.

The different panels correspond to the different sites. In each panel, information from observations (left-hand side) and LPX simulations results (right-hand side) are given.

Observations: the color defines the process for ebullition (green) and diffusion (blue). In the case of no information about the transport processes, white is used. The measured ebullition does not distinguish between vegetation types.

Modeling: the color of the bar defines the emissions process (diffusion: blue; by plant: red; ebullition: green). Results of the simulations 1-7 are given (cf. Table 3). Main characteristics of each simulation is added at the top of each column. For simulations 1-3, error bars show the uncertainty related to the used set of parameters (cf. Table 3). For each LPX simulation, the pie charts give the vegetation distribution (yellow: flood-tolerant grasses; grey: flood-tolerant trees; magenta: other vegetation). For simulations 1-3, three pie charts are given, corresponding to simulations with different parameter values (cf. the second column of Table 3).

Note that observations on open-water spots and Supp. Site 3 are discussed in Sect. 4.

Note also that, given the lack of information (J. Melack, personal information, 2012), the plotted diffusive fluxes are estimated by a mean of all performed measurements given in Belger et al. (2010) without accounting for the distribution of these measurements in time.

is very small. Floating macrophytes are not accounted for in the model, which could explain the difference in the observations. In the optimized run, ebullition replaces plantmediated transport with little impact on the contribution of diffusion. Thus, the contribution of diffusion in the optimal run is still smaller than the observed yearly minimum (i.e., during high water level). There is no seasonality in the contribution of each type of transport to the total flux in LPX.

For site 4, prescribed WTD leads to only a slight reduction in flux densities (from 107.1 in simulation 1 to 101.6 in simulation 2). There are no floodplains in PCR-GLOBWB at site 5 and therefore simulation 1 shows no $\mathrm{CH}_{4}$ flux density at this site. At both sites, the correction of NPP by $a_{\text {NPP }}$ reduces the emissions by about $23 \%$. In simulations $1-3$, the grid cells are entirely covered by grasses for both sites 4 and 5 ; thus, these simulations are similar to simulation 5 .

To summarize the comparison with site observations, it seems that LPX roughly reproduces the magnitude of observed net $\mathrm{CH}_{4}$ flux densities but with a tendency to overestimate emissions at some sites. LPX is less able to reproduce 

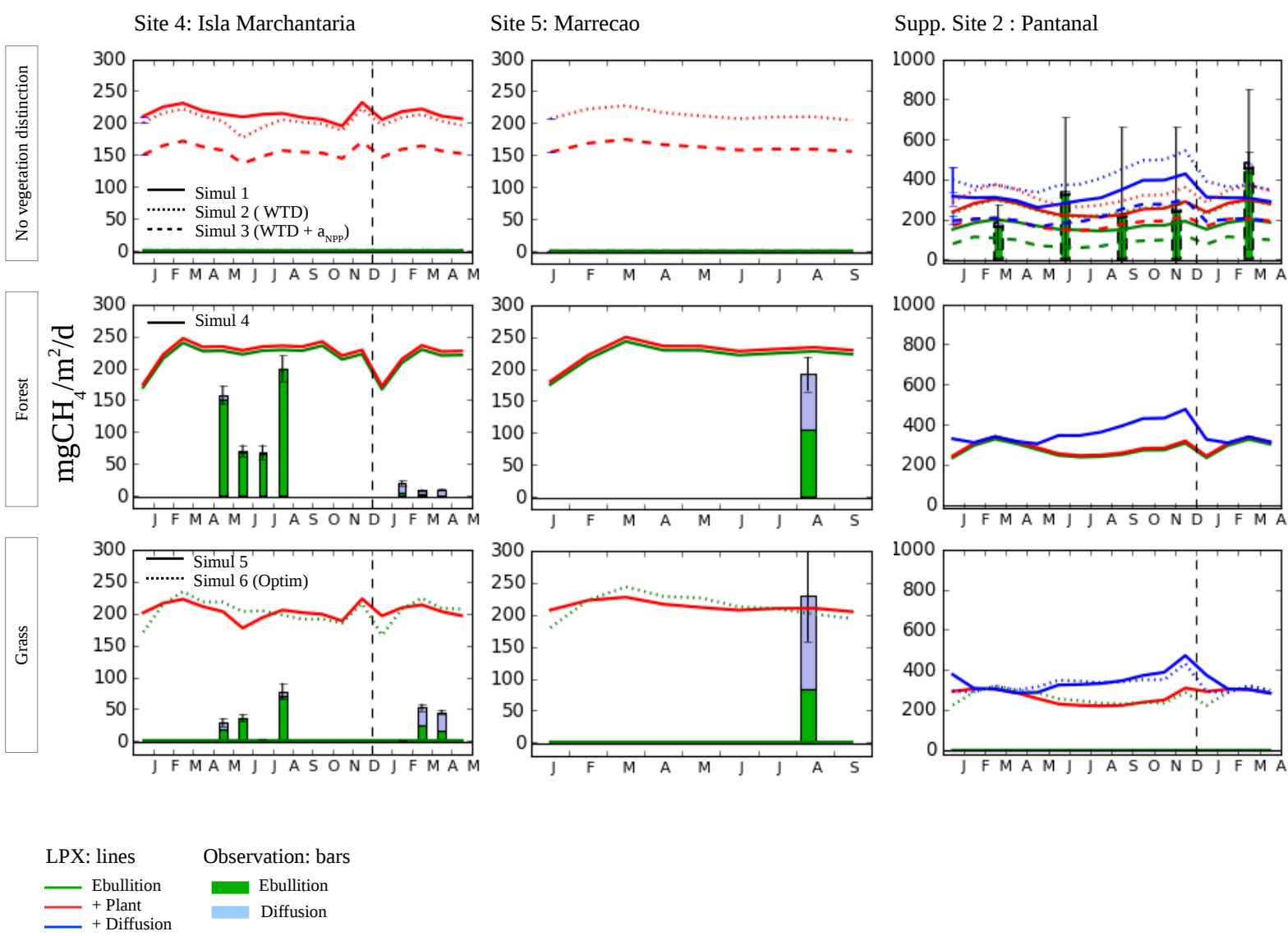

Fig. 6. Comparison of mean annual $\mathrm{CH}_{4}$ flux densities between LPX simulations and observations at sites 4, 5 and Supp. Site 2. For these sites, monthly information about $\mathrm{CH}_{4}$ flux density is available. The different columns correspond to the different sites. For each site, three panels are given: without distinction in vegetation (top), for flooded forest (middle) and flooded grassland (bottom). The LPX optimal simulation is added in last panel.

the variability among sites. Also, variability in time at a given site seems to be difficult to capture, which could be explained by the absence of lateral fluxes of oxygen-rich water in the model. LPX simulates larger $\mathrm{CH}_{4}$ flux densities at flooded forest sites than at grass-covered sites but it is difficult to verify this difference with the available observations (e.g., no vegetation distinction in ebullition in Belger et al., 2010). Floating macrophytes have so far not been represented in the model. Despite the obvious impact of this omission on the representation of transport, it seems to have a weak effect on total $\mathrm{CH}_{4}$ flux density. LPX-simulated diffusion seems to be underestimated in floodplains along the Amazon main stem. LPX shows a large sensitivity of transport pathways to vegetation cover, which is difficult to validate since the contribution of plant-mediated transport to the observed fluxes is often unclear. In the absence of floating macrophytes and lateral exchange in LPX, our current parameterization may be better suited for simulating $\mathrm{CH}_{4}$ flux densities in interfluvial wetlands in the Negro River basin as described in Belger et al. (2010) than along the Amazon main stem.

\subsection{2 $\mathrm{CH}_{4}$ emissions for the Amazon Basin}

\section{Evaluation against measurement inventories}

Figure 7 compares mean $\mathrm{CH}_{4}$ flux densities from LPX to interpolated observations along the Amazon River main stem $(\sim 1700 \mathrm{~km})$ (Area no. 1 in Table 6, top panels of Fig. 7) and in a region around Manaus (Area no. 2 in Table 6, middle panels of Fig. 7). No upscaling estimates are available for the emissions from the Negro River floodplains and these floodplains are therefore not included here. No information derived from the site scale has been used to force LPX; vegetation cover was simulated internally and WTD is from PCR-GLOBWB as described in Sect. 2. Open-water measurements (first bar of each left-hand panel) will be discussed in Sect. 4.

An interesting feature derived from the observations in floodplains along the Amazon River main stem (Fig. 7 top panel) concerns the larger $\mathrm{CH}_{4}$ flux densities associated with floating macrophytes than with flooded forests (average over measurement period: $240.7 \pm 64.0$ for floating 

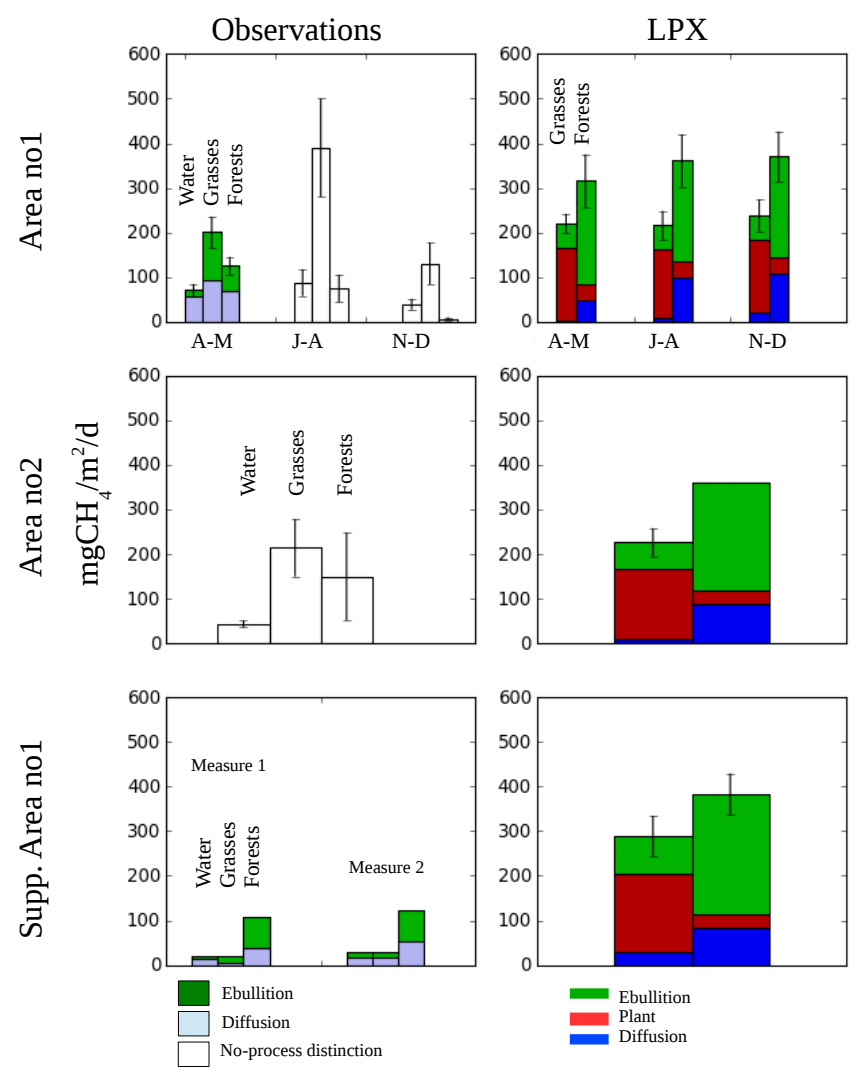

Fig. 7. Comparison between observed/simulated $\mathrm{CH}_{4}$ flux densities over large geographical areas. The three rows of figures correspond to the different geographical areas defined in Table 6.

Observations are shown in left hand panels while LPX simulations are plotted in the right column. Error-bars given for LPX correspond to variability between simulations described in Table 5 and ways to select the grid cells to compute the mean $\mathrm{CH}_{4}$ flux density (i.e., ways to define a grid cell as flooded forest or flooded grass; see Appendix A).

macrophytes (grasses) vs. $69.4 \pm 18.1 \mathrm{mg} \mathrm{CH}_{4} \mathrm{~m}^{2} \mathrm{~d}^{-1}$ for flooded forests). This difference is not significant for the region around Manaus, where most of the studies on sites discussed in Sect. 3.3.1 were performed (Fig. 7 - middle line). Note, however, that the measurements from geographical regions 1 and 2 do not represent the same time of year (cf. Table 6). In addition, an unknown contribution to this difference may come from differences in flooding depth between these forest and grassland ecosystems. LPX simulates larger $\mathrm{CH}_{4}$ flux densities for tree than for grass-dominated areas for all studied periods (e.g., along the Amazon River main stem: $225.0 \pm 30.0$ for grass and $349.3 \pm 58.0$ for forest). The mismatch between LPX and observations is larger for forests than for grasses. In the region around Manaus, LPX captures the magnitude of $\mathrm{CH}_{4}$ flux densities well over grass (LPX: $226.5 \pm 31.7$ vs. $214.0 \pm 64.0$ ) and overestimates fluxes over forest $(359.9 \pm 0.8$ for LPX vs. $150.0 \pm 98.0)$. These results are relatively insensitive to the specifics of the procedure used to attribute a vegetation type to each grid cell (see Appendix A).

For floodplains along the Amazon River main stem, the observed $\mathrm{CH}_{4}$ flux densities for the two vegetation types show a different seasonality. The amplitude of the seasonal cycle is larger for floating macrophytes than for forests. In particular, a large increase in $\mathrm{CH}_{4}$ flux density is observed for floating macrophytes during the period July-August $(\sim+95 \%$ as compared to April-May). The LPX-simulated seasonal amplitudes for inundated forest and grassland are much smaller than observed.

For the same reasons as discussed in Sect. 3.2.1, the LPXsimulated contribution of different transport pathways is difficult to evaluate.

\section{Comparison to WETCHIMP models}

Figures 8, 9 and 10 display $\mathrm{CH}_{4}$ flux densities, wetland extent and $\mathrm{CH}_{4}$ emissions in the Amazon Basin for the current LPX version and the WETCHIMP models, respectively. The magnitude of the Amazon-integrated wetland $\mathrm{CH}_{4}$ emissions are summarized in Table 7.

The agreement among the various WETCHIMP models is poor for the Amazon Basin in terms of both $\mathrm{CH}_{4}$ flux densities (Fig. 8) and $\mathrm{CH}_{4}$ emissions (Fig. 10), as found previously at global scales (Melton et al., 2013). With the exception of SDGVM (Hopcroft et al., 2011), the agreement among the WETCHIMP models is better for wetland extent (Fig. 9): all models account for wetlands along the Amazon River main stem, Negro River and in the Pantanal. This pattern could be explained by the common use of the remote-sensing-derived inundation data set of Papa et al. (2010) as prescribed or prognostic wetland map in most of the WETCHIMP models. SDGVM is characterized by an extreme imbalance between the contribution of each component $\left(\mathrm{CH}_{4}\right.$ flux densities and wetland extent) as compared to other WETCHIMP models (Melton et al., 2013; Ringeval et al., 2013). LPX wetland extents (Fig. 9) are characterized by high floodplain fractions in many grid cells (see Sect. 3.1). The use of GLC2000 to retain only grid cells where the floodplain extent exceeds $2 \%$ of the grid cell yield a spatial pattern that is in better agreement with the other WETCHIMP models.

Two distinct patterns of $\mathrm{CH}_{4}$ flux densities in the Amazon Basin are found among the WETCHIMP models. LPJ-Bern (Wania et al., 2010; Spahni et al., 2011; Zürcher et al., 2011), DLEM (Tian et al. 2010, 2011; Xu et al., 2010) and LPJWSL (Hodson et al., 2011) show larger $\mathrm{CH}_{4}$ flux densities along the Amazon River than elsewhere in the basin, while SDGVM (Hopcroft et al., 2011), ORCHIDEE (Ringeval et al., 2011) and CLM4Me (Riley et al., 2011) simulate more homogeneous $\mathrm{CH}_{4}$ flux densities throughout the basin. The pattern simulated by LPX is, however, characterized by (i) low ( $\left.<180 \mathrm{mg} \mathrm{CH}_{4} \mathrm{~m}^{-2} \mathrm{~d}^{-1}\right) \mathrm{CH}_{4}$ flux densities in grid cells closest to the rivers, (ii) medium $\mathrm{CH}_{4}$ flux densities (180$420)$ in grid cells further away and (iii) highest ( $>420)$ flux 

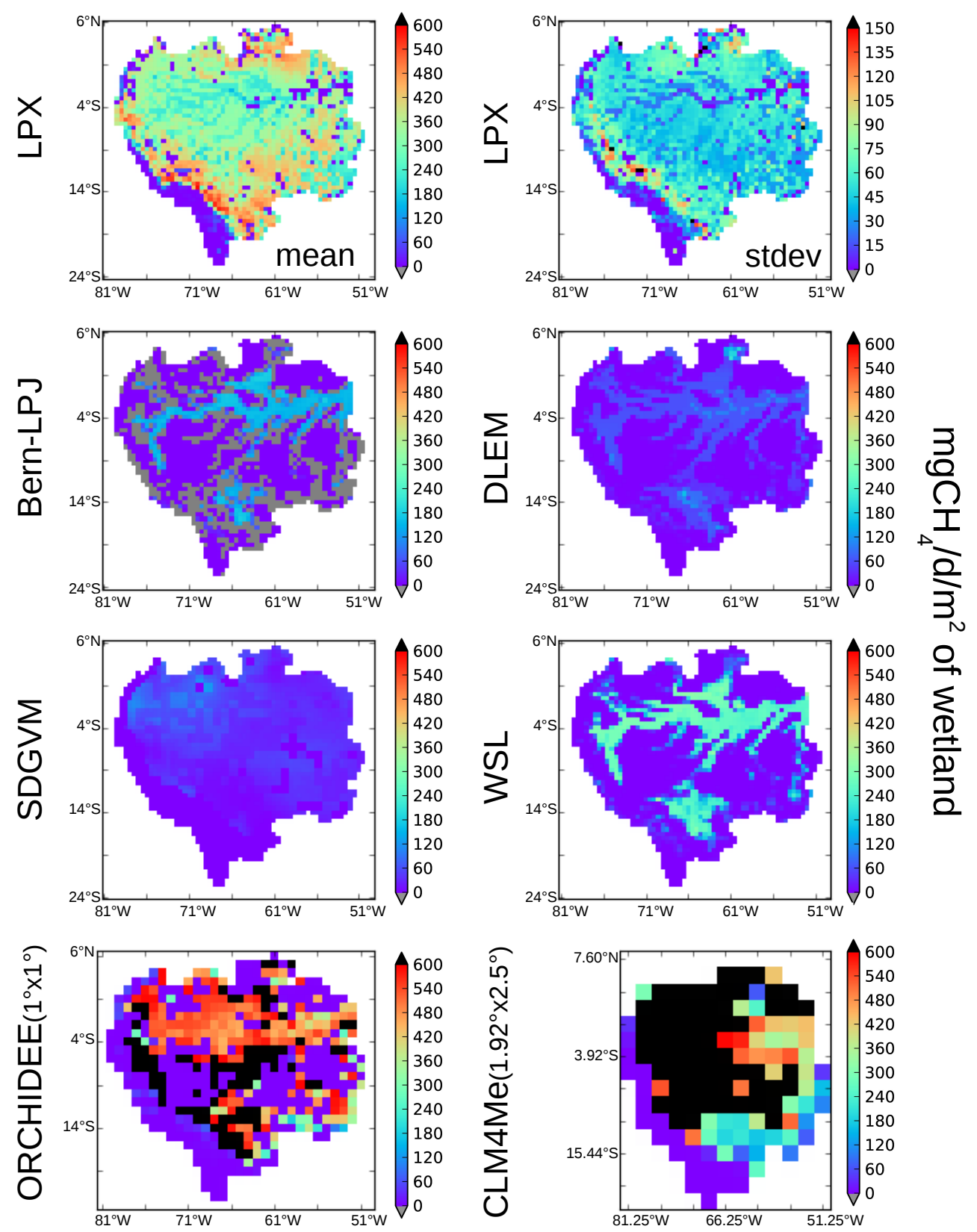

Fig. 8. $\mathrm{CH}_{4}$ flux densities ( $\mathrm{mg} \mathrm{CH} \mathrm{CH}^{-1} \mathrm{~m}^{-2}$ of wetland) for LPX (top line; left: mean between the seven simulations of the Table 4; right: std between the same seven simulations) and six models participating in WETCHIMP. Note that both ORCHIDEE and CLM4Me have a resolution different from $0.5^{\circ}$ lat $\times 0.5^{\circ}$ lon (respectively $1^{\circ} \times 1^{\circ}$ and $1.9 \times 2.5^{\circ}$ ) .

densities at the boundary of the basin. Nevertheless, the maximum values obtained by LPX are lower than those of ORCHIDEE and CLM4Me. In CLM4Me, this is probably due to an overestimation of the NPP simulated in the Amazon region (Bonan et al., 2012). The LPX-simulated spatial distribution of $\mathrm{CH}_{4}$ flux densities could be explained by two factors: larger grass cover in grid cells around the river (and thus lower $\mathrm{CH}_{4}$ flux densities; cf. above) and lower WTD in grid cells at the boundary of the basin, leading to less oxidation.
Concerning the Amazon-integrated wetland $\mathrm{CH}_{4}$ emissions (Fig. 10 and Table 7), two patterns can be distinguished among the model outputs: models with annual emissions lower than $10 \mathrm{Tg} \mathrm{yr}^{-1}$ (LPJ-Bern and DLEM) and models that simulate very high Amazon emissions $\left(>50 \mathrm{Tg} \mathrm{yr}^{-1}\right.$; ORCHIDEE, SDGVM, CLM4Me). WSL is intermediate between these two with emissions around $20 \mathrm{Tg} \mathrm{yr}^{-1}$. An interesting feature is also the high spread variation in the Amazon contribution to the total global emissions (between 6 and $30 \%$, cf. Table 7). Amazon LPX emissions are higher 

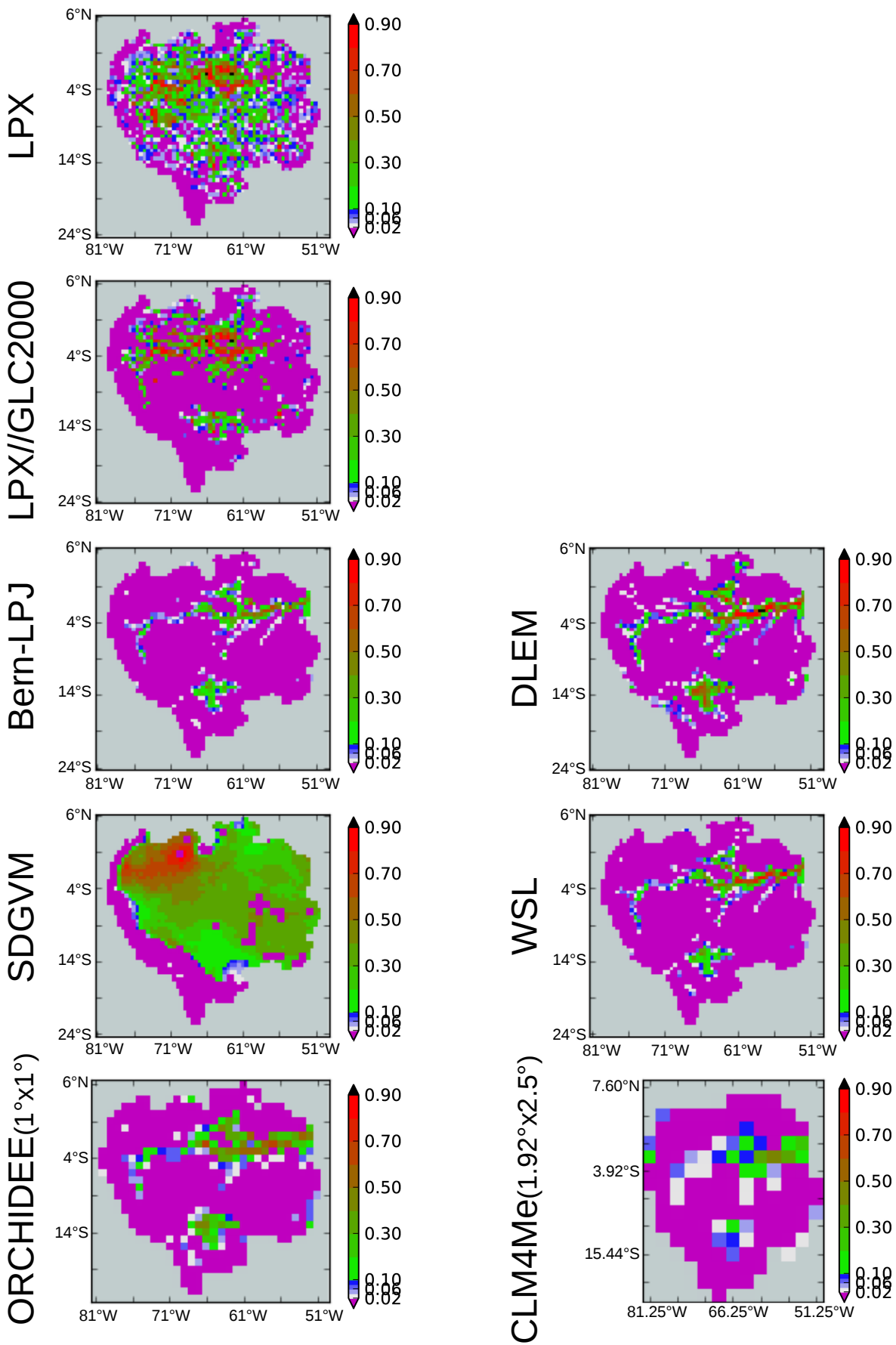

Fig. 9. Wetland extents (total grid-cell fraction, unitless) for LPX (top line) and six models participating in WETCHIMP. The second line (LPX//GLC2000) corresponds to the same wetland extent as shown in the first line after filtering for grid cells that contain floodplains in GLC2000.

than those of any other model $\left(\sim 89.1 \pm 9.3 \mathrm{Tg} \mathrm{yr}^{-1}\right)$ and remain in the upper range after the GLC2000 mask is applied ( $\sim 44.4 \pm 4.8 \mathrm{Tg} / \mathrm{yr})$. The reduction in $\mathrm{LPX}^{\mathrm{CH}} \mathrm{CH}_{4}$ emissions obtained for the Amazon Basin with the application of the GLC2000 mask (factor of 2) is close to the reduction in area fraction ( $\left(\mathrm{fldf}_{\text {mean }}\right.$ ) with this same mask (factor of 1.8 smaller; see Sect. 3.1), suggesting that the "masked" area emits per $\mathrm{m}^{2}$ just a little bit less than the "non-masked" area. The realism of Amazon LPX emissions is discussed in Sect. 4.

Our simulation set-up (simulation scenarios 1-7) allows us to estimate the sensitivity of floodplain $\mathrm{CH}_{4}$ emissions to specific processes (last column of Table 5). First, the 

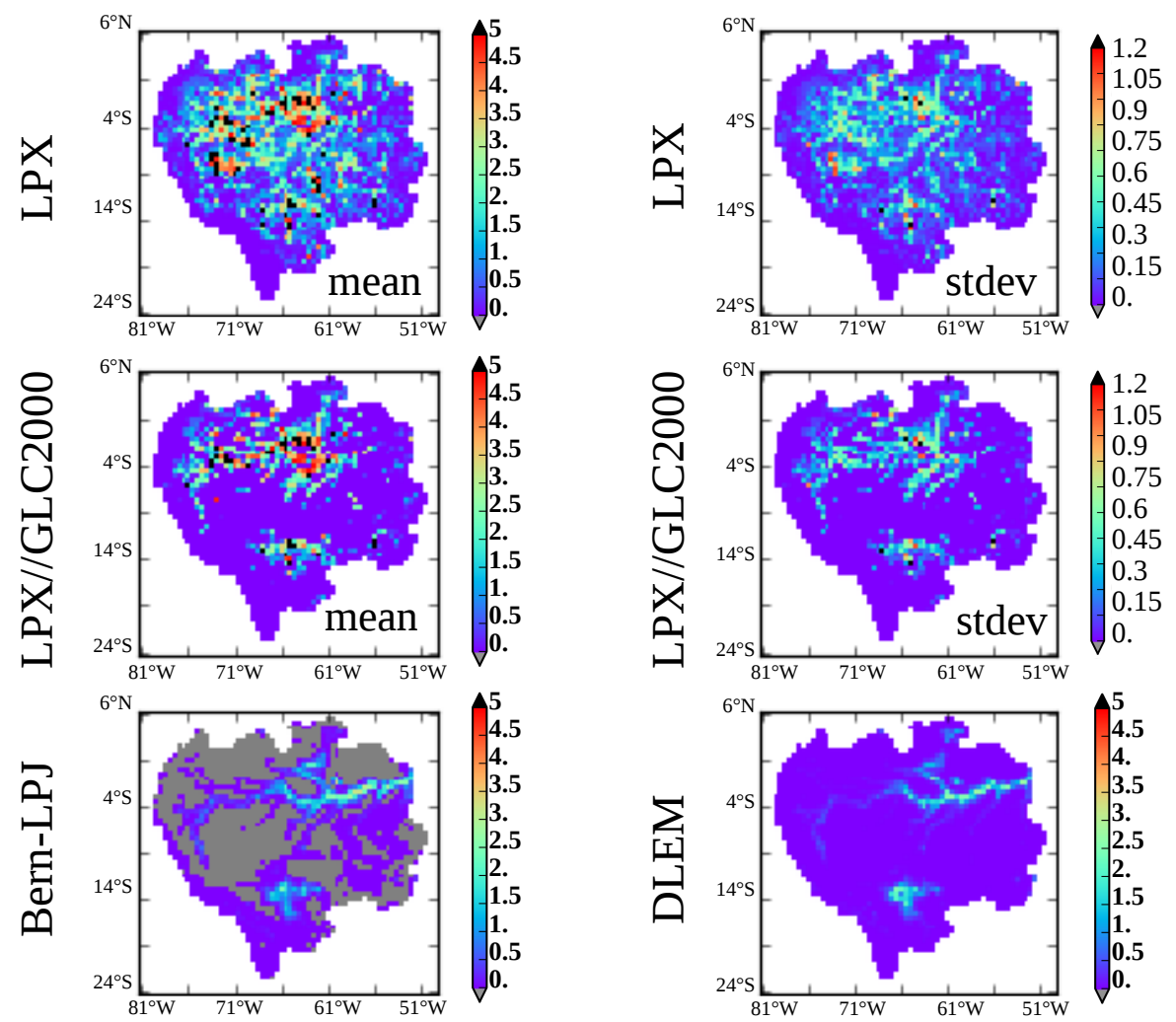

1.2
-1.05
-0.9
0.75
-0.6
0.45
-0.3
0.15
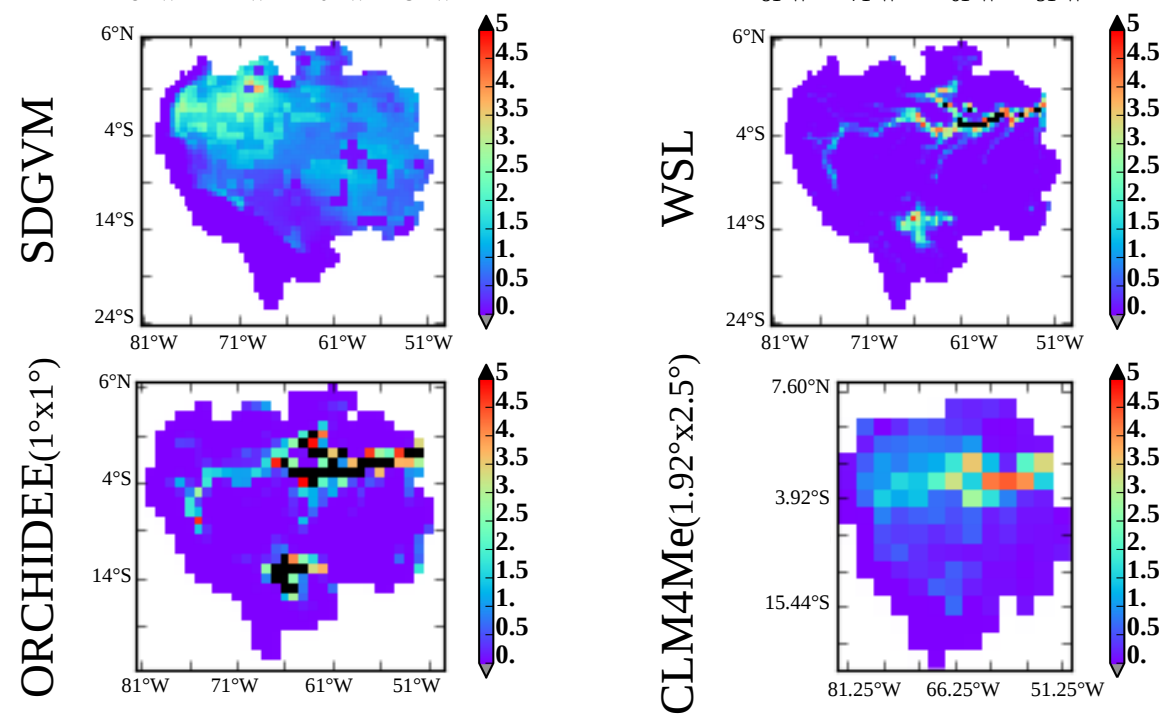

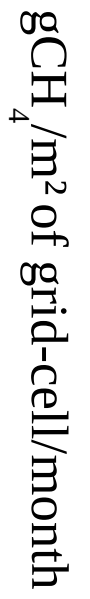

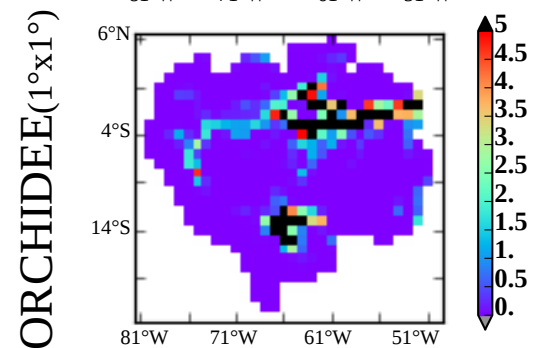

Fig. 10. $\mathrm{CH}_{4}$ emissions $\left(\mathrm{g} \mathrm{CH}_{4}\right.$ month ${ }^{-1} \mathrm{~m}^{-2}$ of grid cell) for LPX (top line; left: mean between the seven simulations of Table 4; right: std between the same seven simulations) and six models participating in WETCHIMP. The second line (LPX//GLC2000) gives emissions after filtering for grid cells that contain floodplains in GLC2000. Because of the different resolution for ORCHIDEE and CLM4Me, the emissions are given per $\mathrm{m}^{2}$ of grid cell.

LPX emissions are very sensitive to vegetation distribution. Simulations 1 and 2 are characterized by the same basinintegrated contribution of grasses to vegetation cover (Fig. 2 and Sect. 3.2.1). However, the change in vegetation distribution within the basin, induced by the difference in flood stress parameterization, leads to an increase in emissions by about $20.2 \%$ from simulation 1 to 2 . The stress parameterization also indirectly affects the mortality rate of plants that die during transitions from floodplain to non-floodplain or viceversa. Dead organic matter ends up being used as a substrate for methanogenesis. A change in the flooding depth and its indirect effect on vegetation distribution (from simulation 1 
to 3) leads to a slight decrease of $3.6 \%$, whereas the application of a NPP correction ( $a_{\text {NPP }}$ scaling factor) reduces the Amazon emissions by $11.3 \%$. Figures 3 a shows that the $a_{\mathrm{NPP}}$ ratio is larger (respectively lower) than unity in the east (respectively west) of the basin. Therefore, the reduced emissions in simulation 3 are partly explained by floodplains located in the west of the basin. Accounting for variations in $\mathrm{O}_{2}$ concentrations in the computation of methanogenesis (Eq. 5) leads to almost no modification in Amazon emissions (simulation 1 to $5:+0.1 \%$ ). The implementation of Eq. (5) could have an effect at site scale, when the prescribed flooding depth is equal to 0 during part of the seasonal cycle but the effect is much smaller when PCR-GLOBWB flooding depths are used. Indeed, most emitting areas are characterized by a large flooding depth in PCR-GLOBWB, which strongly limits $\mathrm{O}_{2}$ diffusion. Finally, a shut down of plant-mediated transport and absence of exudates lead to very small decrease in Amazon emissions (simulation 1 to 6 : $-0.7 \%$ ). In simulation 6 , the effect of reduction in exudates on methanogenesis substrate is negligible and the ebullition increase almost entirely counterbalances the decrease in plant-mediated transport. The introduction of IAV in floodplain extent in the last 30 years of simulation leads to an emission increase of $6.6 \%$ (from simulation 1 to 7). This is explained by an increase in methanogenesis substrate due to higher tree mortality. This increase results partly from the set-up of simulation 7 and the perturbation following the artificial introduction of IAV in floodplain extent in 1979.

Figure 11a and $\mathrm{b}$ displays the mean seasonal cycle of wetland extent over 1993-2004 (Fig. 11a) and associated $\mathrm{CH}_{4}$ emissions (Fig. 11b). Seasonal cycles were normalized by dividing each curve by its annual maximum. Again, a large variation is found among the WETCHIMP models concerning phasing (month of maximum/minimum) and amplitude of the seasonal cycle of both wetland extent (Fig. 11a) and $\mathrm{CH}_{4}$ emission (Fig. 11b). For almost all WETCHIMP models, the relative amplitude is larger for $\mathrm{CH}_{4}$ emissions than for wetland extent. Both wetland extent and emissions show a maximum value between March and April and a minimum extent between September and November. The PCRGLOBWB-derived floodplain extent shows a similar pattern, but is characterized by a seasonal amplitude in the low end of the range of the WETCHIMP models ( $\max -\min$ is equal to $27 \%$ of the maximum annual value). The amplitude of the seasonality in LPX-emissions is very low ( $20 \%$ of the maximum value) and shows an opposite pattern (black curve) with slightly larger emissions during September-October and lower emissions during March-May. As explained in Sect. 2.2.1, a yearly constant floodplain fraction is used as input of LPX (fldf mean $_{\text {}}$ ) but a part of the seasonality in the wetland extent is transferred into seasonality of flood depth (Eqs. 1 and 2). To evaluate the sensitivity to yearly constant floodplain fraction, we applied a posteriori the seasonality in floodplain extent by multiplying for each grid cell the simulated $\mathrm{CH}_{4}$ emission by the seasonal cycle of
PCR-GLOBWB-simulated floodplain extent (orange curve in Fig. 11b). It is worth mentioning that, in this test, the flooding depth seasonality given by Eqs. 1 and 2 was still used. The a posteriori multiplication of emissions cannot allow us to account for the effect of seasonality in floodplain extent on whole carbon cycle (vegetation distribution, heterotrophic respiration, etc.) but only for its direct effect on $\mathrm{CH}_{4}$ emissions (through change in emitting areas). We found that this procedure reconciles the phase of the LPX-seasonality with that of the WETCHIMP models, whereas the simulated seasonal amplitude remains smaller in LPX than in other models (Fig. 11b). This underlines the difficulty in making a corresponding link between horizontal and vertical seasonality in hydrology. While a flooding depth increase tends to decrease emissions due to increased oxidation, increased floodplain extent leads to increased emissions.

Figure $11 \mathrm{c}, \mathrm{d}$ shows the IAV in wetland extent and $\mathrm{CH}_{4}$ emissions of the WETCHIMP models and LPX. At the Amazon Basin scale, some common features are found in ORCHIDEE and SDGVM on the one hand and DLEM and WSL on the other hand. LPJ-Bern does not account for IAV in the wetland extent (blue curve in Fig. 11c; cf. experiment 2 in Wania et al., 2013). The IAV of the PCR-GLOBWBderived floodplain extent is smaller than simulated by the WETCHIMP models. The introduction of the GLC2000 filter in LPX does not influence the IAV variability in $\mathrm{CH}_{4}$ emissions in LPX. The black curve in Fig. 11d represents the IAV in emissions averaged over simulations 1-6 and thus does not account for IAV in the floodplain extents. Therefore, this IAV only reflects the IAV of the $\mathrm{CH}_{4}$ flux densities, which turns out to be insensitive to the differences between simulations 1-6. This black curve can be compared to the blue curve, which represents a simulation of LPJ-Bern without IAV in wetland extent. The absolute $\mathrm{CH}_{4}$ emission variability in the LPJ-Bern model (blue) is larger than in the LPX model (black) by about $+80 \%$. The difference between the two models results either from the modifications in floodplain vegetation introduced in this study or from a difference in the spatial distribution of wetlands. The use of PCRGLOBWB calculated IAV in floodplain extent increases the IAV of the emissions by about $+93 \%$ (from the black curve to orange one in Fig. 11d), even though the IAV of floodplain extent is low as compared to WETCHIMP models (Fig. 11c). Despite this $+93 \%$ increase, the IAV of the LPX-emissions remains lower than most of the WETCHIMP models. The IAV in the floodplain extent affects $\mathrm{CH}_{4}$ emissions directly through a change in emitting areas and indirectly through modifications in vegetation cover; the two effects cannot be separated here.

\section{Discussion and conclusions}

We adapted the LPX model, which was initially developed for boreal $\mathrm{CH}_{4}$ emissions (Wania et al., 2010), to include 

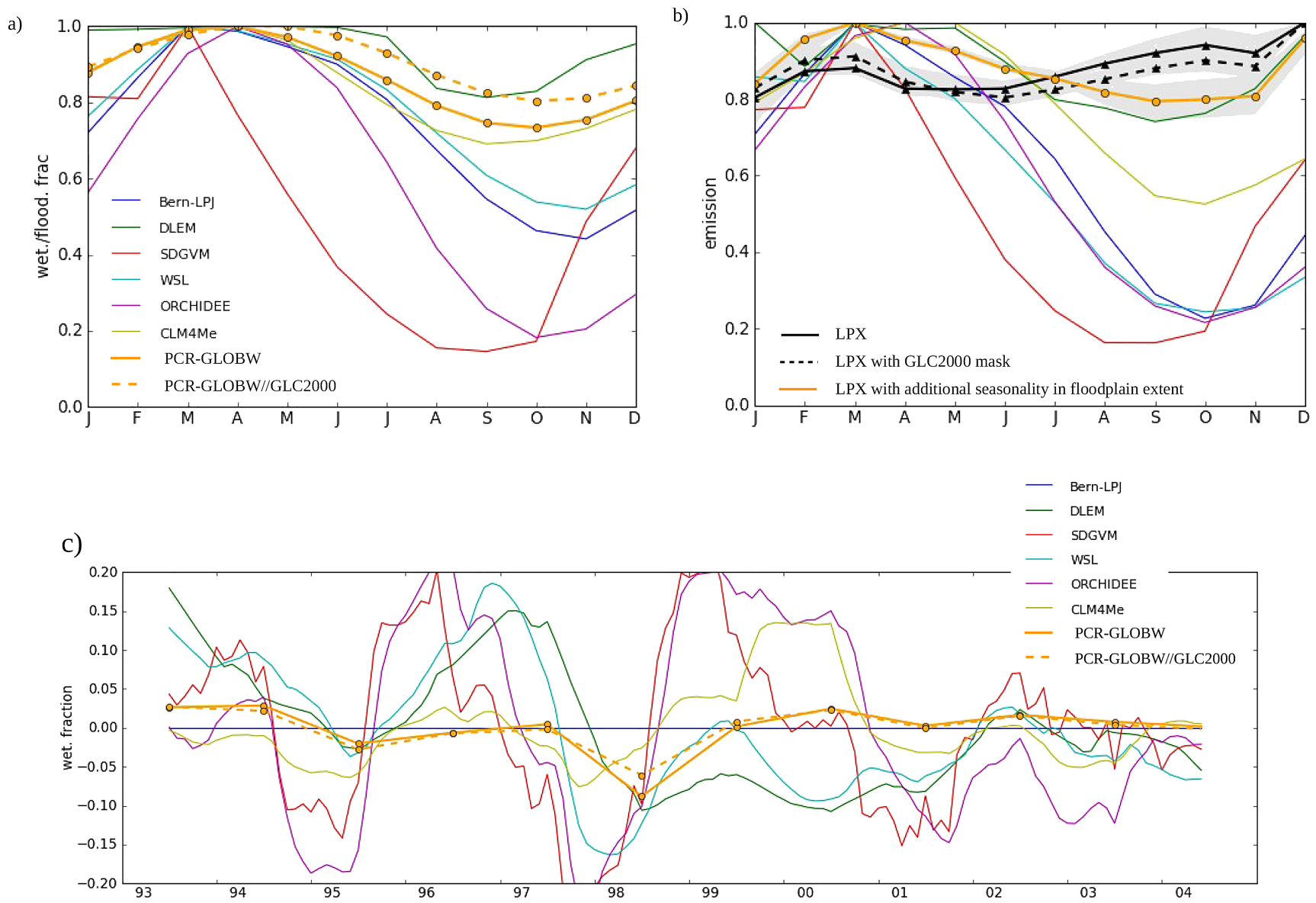

d)

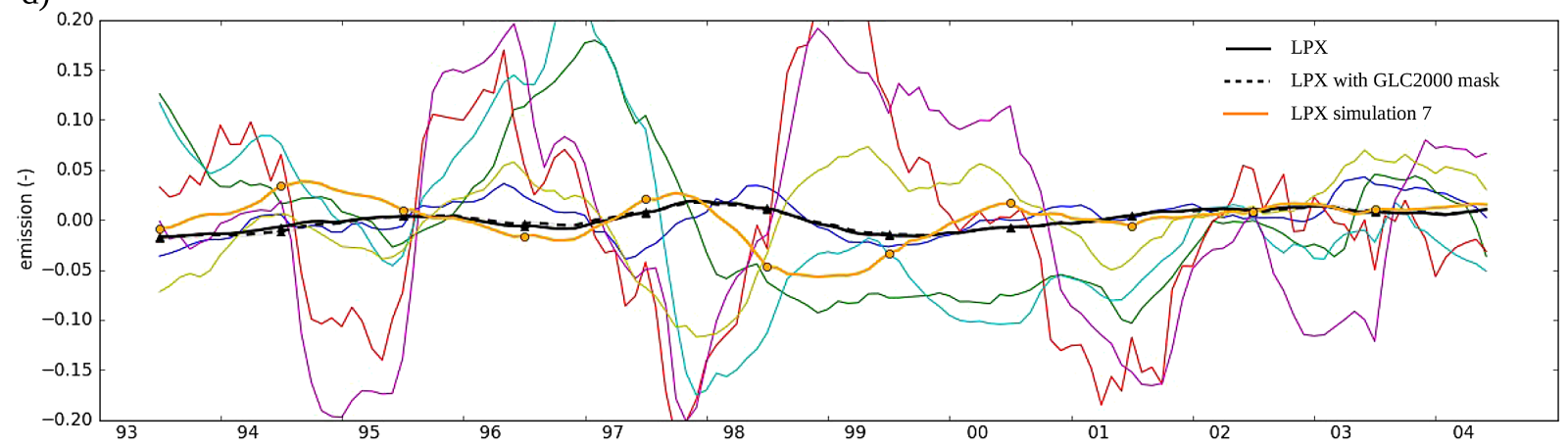

Fig. 11. Comparison of the temporal variability (seasonal and IAV) in wetland extent and associated $\mathrm{CH}_{4}$ emissions between WETCHIMP models and LPX. For LPX-floodplain $\mathrm{CH}_{4}$ emissions (panels $\mathbf{b}$ and $\mathbf{d}$ ), the grey area corresponds to a range ( $\mathrm{max}-\mathrm{min}$ ) of the simulations 1-6 (cf. Table 5) while the black line corresponds to the mean of the same simulations. In the same panels, the orange curve corresponds to emissions when the corresponding (either seasonal or interannual) variability in flood extent is accounted for to compute emissions (see below for specificities about the seasonal cycle). The dashed line corresponds to the application of the GLC2000 filter to the PCR-GLOBWB floodplain extent.

(a-b) Mean seasonal cycle over 1993-2004 in the Amazon Basin of (a) the wetland extent and (b) the associated $\mathrm{CH}_{4} \mathrm{emissions}$ Seasonality of wetland extent and $\mathrm{CH}_{4}$ emissions have been normalized by dividing each curve by its maximum. Orange curves in panel ( $a$ ) (solid and dash lines) correspond to floodplain extent given by PCR-GLOBW. Seasonality in floodplain extent is not used directly in LPX (yearly constant fractions are prescribed in LPX; see Sect. 2.2.1). The seasonal cycle simulated by PCR-GLOBWB is used a posteriori to estimate the sensitivity to seasonality in the floodplain extent (orange curve in b). Note however that these emissions account for larger seasonality in the flood depth (introduced to counterbalance the yearly constant fraction; see Sect. 2.2.1).

(c-d) Year-to-year variability in (c) the wetland extent and (d) associated $\mathrm{CH}_{4}$ emissions over the 1993-2004 period. Each curve corresponds to a 12-month running mean divided by the mean annual extent/emissions over the studied period. 
Amazon floodplain specificities. Our modifications aimed to represent tropical floodplain hydrology, vegetation and associated $\mathrm{CH}_{4}$ emissions (see below). These modifications lead to substantial improvements in terms of modeling approach but do not reduce the uncertainty in Amazon wetland emissions. However, the advanced treatment of floodplains made uncertainties and challenges about hydrology, vegetation and associated $\mathrm{CH}_{4}$ emissions explicit. These challenges relate to (i) the need for observational and experimental work necessary to mechanistically represent these additional processes, and (ii) uncertainties in formulation and parameterization of processes that were included and in processes that were neglected in our first step procedure. In addition, we discuss below the challenges towards the modeling of tropical $\mathrm{CH}_{4}$ emissions outside of the Amazon Basin.

\subsection{Observations needed to reduce the uncertainty in Amazon $\mathrm{CH}_{4}$ emissions}

LPX-simulated $\mathrm{CH}_{4}$ flux densities are in reasonable agreement with the average magnitude of observed net $\mathrm{CH} 4$ flux densities at site scale. However, variability in $\mathrm{CH}_{4}$ emissions between sites and in time at the same site were not well modeled. The reasons for these differences are only partly understood, as field observations are too scarce to constrain the different transport pathways or the difference of emissions between grass-covered and forest-covered plots. This prevents one from drawing quantitative conclusions. Riley et al. (2011) pointed out that it is possible to simulate the fluxes well for a given location, but with incorrect contributing processes, such as production, oxidation, or transport. Thus, not only the net soil/atmosphere flux but also site-level information about the different components of the flux are required. Also, as recommended by Melton et al. (2013), there is a need for observation data sets at appropriate spatial and temporal scales for the coarse resolution of LSMs. For example, the spatial cover of flux chamber measurements $\left(0.2 \mathrm{~m}^{2}\right)$ is not compatible with the measurement of ecosystem variables such as NPP or vegetation cover, which are required to evaluate the model variables. Eddy-covariance measurements in the Amazon Basin could provide information that is more compatible with the spatial resolution of LSMs but up to now, they are restricted to uplands (Querino et al., 2011).

In addition, we identified important difficulties in constraining some key variables (floodplain extent, vegetation cover, NPP) at regional scale by observations. This is primordial given the results of our sensitivity tests, which showed the large $\mathrm{CH}_{4}$ emissions sensitivity to such variables. This limitation arises first from uncertainties and inconsistencies in global remote-sensing data sets (Miguez-Macho and Fan, 2012). Given the intrinsic difference between GLC2000 and MODIS, we experienced difficulties when trying to combine both products to estimate floodplain NPP for trees and grasses. In addition, the comparison of remotely sensed NPP with the few available field observations showed a disagreement (Wittmann et al., 2006; Engle et al., 2007).

Given the large variability among the WETCHIMP models, an interesting question is what the size of the seasonal cycle and the year-to-year variability should be. This may be assessed through the use of a chemical-transport model in combination with aircraft measurements. Such data sets are now available (Beck et al., 2012) and offer a good opportunity to further constrain the $\mathrm{CH}_{4}$ emissions at Amazon Basin scale.

\subsection{Current and future required model developments}

While LPX cannot simulate the water cycle related to floodplains, our approach allowed explicitly accounting for floodplain extent through coupling LPX to PCR-GLOBWB outputs. In addition, new PFTs were introduced to improve the representation of floodplain vegetation. Parameterizations were introduced to modify both the vegetation cover and productivity of tropical floodplain as compared to nonfloodplain. From a modeling point of view, our approach is more advanced than most of the WETCHIMP models, because the carbon balance of soils is treated independently for wetlands and uplands. In most of the WETCHIMP models (Melton et al., 2013; Wania et al., 2013) the wetland extent can occupy a fraction of the grid cell, but there is no subgrid treatment of the carbon cycle fluxes. Thus, inundation has no effect on vegetation, carbon pools and heterotrophic respiration. Instead, the mean value of the heterotrophic respiration over the entire grid cell is used to compute the $\mathrm{CH}_{4}$ flux density (see Melton et al., 2013; Ringeval et al., 2013).

We estimated the $\mathrm{CH}_{4}$ emissions' sensitivity to different processes and could identify which processes are critical for a successful bottom-up estimate of $\mathrm{CH}_{4}$ emissions from tropical wetlands. Based on this, the following recommendations can be made for further model improvement. Importantly, in the LPX model environment, it is difficult to account for seasonality in floodplain extent. Due to yearly constant LU extent in the LPX model, our approach was to transfer a part of the horizontal seasonality into vertical (i.e., water depth) seasonality. However, this reverses the influences of water availability on $\mathrm{CH}_{4}$ emissions, in the sense that increases in floodplain extent are expected to increase the $\mathrm{CH}_{4}$ emissions, whereas the LPX-simulated increase in water depth reduces the emissions. A pragmatic solution to this problem would be to account for more than one floodplain LU in LPX. Indeed, introducing a large number of floodplain LUs which can be successively flooded during the year would allow mimicking the seasonality in floodplain extent. As a first attempt, introducing one floodplain LU which is flooded during the whole year and one floodplain LU with a dry season would already allow for the improvement of the representation of seasonality. This solution would allow accounting for the effect of seasonality in floodplain hydrology on both vegetation dynamic and $\mathrm{CH}_{4}$ emissions. 
Besides, at Amazon Basin scale, the year-to-year variability in $\mathrm{CH}_{4}$ emissions from LPX is lower than most of the WETCHIMP models. While the real magnitude of IAV is unknown, as indicated in previous section, LPX-simulated IAV may be enhanced by amplifying the effect of IAV in floodplain extent on the IAV of $\mathrm{CH}_{4}$ flux densities. This could be done, for example, by modifying the soil carbon decomposition in floodplains (through the $R_{\text {moist }}$ parameter). Under steady state in floodplain extent, heterotrophic respiration $\sim \mathrm{NPP}$ and thus the $\mathrm{CH}_{4}$ emissions is only weakly affected by the value of $R_{\text {moist }}$. However, $R_{\text {moist }}$ could be more important when year-to-year variability in floodplain extent is accounted for, as is the case when an increase in floodplain extent tends to inject non-floodplain soil carbon into the floodplain carbon pool. The decomposition of such obtained soil carbon to $\mathrm{CH}_{4}$ is sensitive to $R_{\text {moist }}$. More work is required to estimate the sensitivity of $\mathrm{CH}_{4}$ emissions to $R_{\text {moist }}$.

A second issue relates to the representation of floodplain vegetation in LPX. We experienced difficulties simulating floodplain ecosystems with both (i) a vegetation cover consistent with GLC2000 and (ii) a NPP consistent with MODIS. In LPX, a reduction in tree productivity is required to allow grasses to compete with trees. Following the introduced parameterization, a bimodal behavior is obtained (grid cell either entirely covered by forest or by grassland) except in the case where the amplitude of the seasonal cycle in flooding depth is increased (Eq. 2). A modification of the artificial $5 \%$ threshold for maximum tree cover in the floodplain $\mathrm{LU}$ as a function of flooded conditions in the previous year may improve the model. Trait-based approaches incorporating more plant strategy components (Van Bodegom et al., 2012) might also help. Also, a more realistic and mechanistic representation of flooding stress (e.g., by separating the effects of partial submergence and soil oxygen demand on plant physiology; van Bodegom et al., 2008) may be considered. Such representations do, however, require experimental data on adaptation to these stresses representative for tropical PFTs and require accounting for seasonality in vegetation submergence. Through the big-leaf approach for grasses commonly used in GVMs, LPX cannot provide any information about the length of grass shoots in the course of the year. This prevents varying WTP $_{\max }$ in time and an alternative expression needs to be found. Also, a better representation of plant adaptation to flooded conditions is required. For instance, to account for the fact that some tree species can adapt to both flooded and non-flooded conditions, a correspondence between flood-tolerant and non-flood-tolerant trees of the two LUs could be tested (e.g., for flood-tolerant TrBR, setting in Eq. (4), $L=\{$ flood - tolerant TrBR, TrBR $\}$ ). The introduction of (nitrogen and) phosphorus limitations (Goll et al., 2012) could help to simulate the fertility gradient in Amazon Basin and to improve the representation of the difference in NPP and (through supply of carbon) $\mathrm{CH}_{4}$ emissions between varzeas and igapos. Also, indirectly, nitro- gen and phosphorus dynamics may impact $\mathrm{CH}_{4}$ emissions. The relative availability of nutrients determines litter decomposition and carbon mineralization and therewith methane emissions (Pancotto et al. 2010). Moreover, denitrification and phosphorus-affected soil chemistry will impact soil redox potential; finally, nitrogen limitations are known to affect methane oxidation (Bodelier et al. 2000). Given the ubiquitous impacts of nutrient cycling on processes leading to $\mathrm{CH}_{4}$ emissions, incorporating these cycles is far from straightforward.

Finally, the difference in model performance found between the Negro River basin and the Amazon main stem suggests that the implementation of macrophytes and lateral water flow could be important. Our sensitivity tests showed that the direct effect of macrophytes properties on $\mathrm{CH}_{4}$ emissions (plant-mediated transport, exudates) is likely small. However, differences in productivity and specificities in phenology could have an indirect effect on the $\mathrm{CH}_{4}$ emissions and this remains to be tested. Lateral fluxes of water containing high $\mathrm{O}_{2}$ concentration may also play a role. The representation of lateral flux between the grid cells is problematic in LSMs and we recommend first implementing a parameterization that represents higher $\mathrm{O}_{2}$ concentrations for floodplains close to the main channel and characterized by many pulses of flooding per year.

\subsection{Extrapolation to other tropical wetland ecosystems}

Finally, we investigated if our LPX version could be used to simulate $\mathrm{CH}_{4}$ emissions of open-water bodies in the Amazon Basin. Figure A8 shows a comparison between the LPX simulation and measurements made on plots not covered by vegetation at sites 4 and 5. Figure A8 also displays comparisons on Supp. Site 1 (Lago Colado; Crill et al., 1988; Engle and Melack, 2000). For sites 4 and 5, measurements show that average fluxes from plots covered by water (Fig. A8) are significantly lower than those from floating mats and flooded forests (Fig. 6). This difference is bigger for site 5 than for site 4 . It is difficult to know if the measured plots correspond to vegetated plots which were only punctually covered by water after a rise in the flood height, or if they were permanently inundated. Overall, the order of magnitude of measured fluxes in Lago Colado is similar to the one of sites 4 and 5 , and measured $\mathrm{CH}_{4}$ flux densities are relatively constant for plots covered by water in all sites. $\mathrm{LPX}$-simulated $\mathrm{CH}_{4}$ flux densities are generally much higher and only coincide with measurements in conditions where the water had been mixed: due to the passage of a cold front in September 1987 and the resulting modification of the stratified conditions, a large increase in $\mathrm{CH}_{4}$ flux densities had occurred (Crill et al., 1988). We thus conclude that LPX is not required to simulate openwater emissions and we propose estimating $\mathrm{CH}_{4}$ emissions related to permanent open-water bodies in Amazon Basin by using a constant $\mathrm{CH}_{4}$ flux density. 
We also investigated whether our LPX version can be used to simulate $\mathrm{CH}_{4}$ emissions of floodplains outside of the Amazon Basin. Supp. Sites 2 (Pantanal, Marani and Alvala, 2007) and 3 (Panama, Keller et al., 1990) as well as Supp. Geographical area no. 1 (Orinoco floodplain, Smith et al., 2000) allows us to compare $\mathrm{LPX} \mathrm{CH}_{4}$ flux densities with measurements made outside of the Amazon Basin (Figs. 5, 6 and 7). While measurements and LPX are consistent at site scale, simulations overestimate $\mathrm{CH}_{4}$ flux densities representative to large areas in the Orinoco Basin. Intensive comparison to measurements outside of South America is required to assess if the model could be used for all tropical floodplains.

Acknowledgements. The research leading to these results has received funding from the European Union's Seventh Framework Programme (FP7/2007-2013) under grant agreement no. 283080, project GEOCARBON. The authors would like to thank Roxanna Petrescu for her help with the data from individual sites, Rita Wania for developing the first version of the LPJ-WhyMe, Joe Melton for providing the WETCHIMP model outputs, Beni Stocker for his help with the first LPX simulations and Guillaume Monteil for his help with Linux. RS and FJ acknowledge support by the Swiss National Science Foundation and by the EU FP7 project PAST4FUTURE (grant no. 243908).

Edited by: K. Thonicke

\section{References}

Aragão, L. E. O. C., Malhi, Y., Metcalfe, D. B., Silva-Espejo, J. E., Jiménez, E., Navarrete, D., Almeida, S., Costa, A. C. L., Salinas, N., Phillips, O. L., Anderson, L. O., Alvarez, E., Baker, T. R., Goncalvez, P. H., Huamán-Ovalle, J., Mamani-Solórzano, M., Meir, P., Monteagudo, A., Patiño, S., Peñuela, M. C., Prieto, A., Quesada, C. A., Rozas-Dávila, A., Rudas, A., Silva Jr., J. A., and Vásquez, R.: Above- and below-ground net primary productivity across ten Amazonian forests on contrasting soils, Biogeosciences, 6, 2759-2778, doi:10.5194/bg-6-2759-2009, 2009.

Balsamo, G., Boussetta, S., Lopez, P., and Ferranti, L.: Evaluation of ERA-Interim and ERA-Interim-GPCP-rescaled precipitation over the USA, ERA report series, 5, 10 pp., ECMWF, Reading, available at: http://www.ecmwf.int/publications/library/do/ references/list/782009, 2010.

Baily-Serres, J. and Voesenek, L. A.: Flooding Stress: Acclimations and Genetic Diversity, Annu. Rev. Plant Biol., 59, 313-339, doi:10.1146/annurev.arplant.59.032607.092752, 2008.

Baumgartner, M., Schilt, A., Eicher, O., Schmitt, J., Schwander, J., Spahni, R., Fischer, H., and Stocker, T. F.: High-resolution interpolar difference of atmospheric methane around the Last Glacial Maximum, Biogeosciences, 9, 3961-3977, doi:10.5194/bg-93961-2012, 2012.

Bartlett, K. B., Crill, P. M., Sebacher, D. I., Harris, R. C., Wilson, J. O., and Melack, J. M.: Methane flux from the Central Amazonian Floodplain, J. Geophys. Res., 93, 1571-1582, doi:10.1029/JD093iD02p01571, 1988.

Bartlett, K. B., Crill, P. M., Bonassi, J. A., Richey, J. E., and Harri, R. C.: Methane flux from the Amazon River floodplain: Emis- sions during rising water, J. Geophys. Res., 95, 16773-16778, doi:10.1029/JD095iD10p16773, 1990.

Bartlett, K. B. and Harris, R. C.: Review and assessment of methane emissions from wetlands, Chemosphere, 26, 261-320, doi:10.1016/0045-6535(93)90427-7, 1993.

Beck, V., Chen, H., Gerbig, C., Bergamaschi, P., Bruhwiler, L., Houweling, S., Röckmann, T., Kolle, O., Steinbach, J., Koch, T., Sapart, C. J., Van der Veen, C., Frankenberg, C., Andreae, M. O., Artaxo, P., Longo, K. M., and Wofsy, S. C.: Methane airborne measurements and comparison to global models during BARCA, J. Geophys. Res.-Atmos., 117, D15310, doi:10.1029/2011JD017345, 2012.

Belger, L., Forsberg, B. R., and Melack, J. M.: Carbon dioxide and methane emissions from interfluvial wetlands in the upper Negro River basin, Brazil, Biogeochemistry, 105, 171-183, doi:10.1007/s10533-010-9536-0, 2010.

Bergamaschi, P., Frankenberg, C., Meirink, J. F., Krol, M., Villani, M. G., Houweling, S., Dentener, F., Dlugokencky, E. J., Miller, J. B., Gatti, L. V., Engel, A., and Levin, I.: Inverse modeling of global and regional $\mathrm{CH}_{4}$ emissions using SCIAMACHY satellite retrievals, J. Geophys. Res., 114, D22301, doi:10.1029/2009JD012287, 2009.

Bloom, A. A., Palmer, P. I., Fraser, A., Reay, D. S., and Frankenberg, C.: Large-Scale Controls of Methanogenesis Inferred from Methane and Gravity Spaceborne Data, Science, 327, 322-325, doi:10.1126/science.1175176, 2010.

Van Bodegom, P. M., Douma, J. C., Witte, J. P. M., Ordoñez, J. C., Bartholomeus, R. P., and Aerts, R.: Going beyond limitations of plant functional types when predicting global ecosystematmosphere fluxes: exploring the merits of traits-based approaches, Global Ecol. Biogeogr., 625-636, doi:10.1111/j.14668238.2011.00717.x, 2012.

Van Bodegom, P., Sorrell, B. K., Oosthoek, A., Bakker, C., and Aerts, R.: Separating the effects of partial submergence and soil oxygen demand on plant physiology, Ecology, 89, 193-204, 2008

Bohn, T. J., Lettenmaier, D. P., Sathulur, K., Bowling, L. C., Podest, E., McDonald, K. C., and Friborg, T.: Methane emissions from western Siberian wetlands: heterogeneity and sensitivity to climate change, Environ. Res. Lett., 2, 045015, doi:10.1088/17489326/2/4/045015, 2007.

Bonan, G. B., Oleson, K. W., Fisher, R. a., Lasslop, G., and Reichstein, M.: Reconciling leaf physiological traits and canopy flux data: Use of the TRY and FLUXNET databases in the Community Land Model version 4, J. Geophys. Res., 117, G02026, doi:10.1029/2011JG001913, 2012.

Bousquet, P., Ciais, P., Miller, J. B., Dlugokencky, E. J., Hauglustaine, D. A., Prigent, C., Van Der Werf, G. R., Peylin, P., Brunke, E.-G., Carouge, C., Langenfelds, R. L., Lathière, J., Papa, F., Ramonet, M., Schmidt, M., Steele, L. P., Tyler, S. C., and White, J.: Contribution of anthropogenic and natural sources to atmospheric methane variability, Nature, 443, 439443, doi:10.1038/nature05132, 2006.

Conrad, R.: Control of methane production in terrestrial ecosystems, in: Exchange of Trace Gases Between Terrestrial Ecosystems and the Atmosphere, edited by: Andreas, M. and Schimel, D., 39-58, John Wiley, Hoboken, N. J., 1989

Covey, K. R., Wood, S. A., Warren, R. J., Lee, X. and Bradford, M. A.: Elevated methane concentrations in trees of an upland forest, 
Geophys. Res. Lett., 39, L15705, doi:10.1029/2012GL052361, 2012.

Crill, P. M., Bartlett, K. B., Harriss, R. C., Gorham, E., Verry, E. S., Sebacher, D. I., Madzar, L., and Sanner, W.: Methane flux from Minnesota peatlands, Global Biogeochem. Cy. 2, 371-384, 1988

Denman, K. L., Brasseur, G., Chidthaisong, A., Ciais, P., Cox , P., Dickinson, R. E., Hauglustaine, D., Heinze, C., Holland, E., Jacob, D., Lohmann, U., Ramachandra, S., da Silva Dias, P. L., Wofsy, S., and Zhang, X.: Couplings between changes in the climate system and biogeochemistry, in: Climate Change 2007: The Physical Science Basis. Contribution of Working Group I to the Fourth Assessment Report of the Intergovernmental Panel on Climate Change, edited by: Solomon, S., Qin, D., Manning, M., Chen, Z., Marquis, M., Averyt, K. B., Tignor, M., and Miller, H. L., Cambridge University Press, Cambridge United Kingdom and New York, NY, USA, 498-587, 2007.

Devol, A. H., Richey, J. E., Clark, W. A., King, S. L., and Martinelli, L. A., Methane emissions to the troposphere from the Amazon floodplain, J. Geophys. Res., 93, 1583-1592, 1988

Devol, A. H., Richey, J. E., Forsberg, B. R., and Martinelli, L. A.: Seasonal dynamics in methane emissions from the Amazon River floodplain to the troposphere, J. Geophys. Res., 95, 1641716426, 1990.

Engle, D. and Melack, J. M.: Methane emissions from an Amazon floodplain lake: Enhanced release during episodic mixing and during falling water, Biogeochemistry, 51, 71-90, 2000

Engle, D. L., Melack, J. M., Doyle, R. D., and Fisher, T. R.: High rates of net primary production and turnover of floating grasses on the Amazon floodplain: implications for aquatic respiration and regional $\mathrm{CO}_{2}$ flux, Glob. Change Biol., 14, 369-381, doi:10.1111/j.1365-2486.2007.01481.x, 2007.

Flury, S., McGinnis, D. F., and Gessner M. O.: Methane emissions from a freshwater marsh in response to experimentally simulated global warming and nitrogen enrichment, J. Geophys. Res., 115, G01007, doi:10.1029/2009JG001079, 2010

Gedney, N. and Cox, P. M.: The Sensitivity of Global Climate Model Simulations to the Representation of Soil Moisture Heterogeneity, J. Hydrometeorol., 4, 1265-1275, doi:10.1175/15257541(2003)004, 2003.

Gerten, D., Schaphoff, S., Haberlandt, U., Lucht, W., and Sitch, S.: Terrestrial vegetation and water balance - hydrological evaluation of a dynamic global vegetation model, J. Hydrol., 286, 249270, doi:10.1016/j.jhydrol.2003.09.029, 2004.

Global Land Cover 2000 database. European Commission, Joint Research Centre, available at: http://bioval.jrc.ec.europa.eu/ products/glc2000/glc2000.php, 2003.

Gleeson, T., Wada, Y., Bierkens, M. F. P., and Van Beek, L. P. H.: Water balance of global aquifers revealed by groundwater footprint., Nature, 488, 197-200, doi:10.1038/nature11295, 2012.

Gloor, M., Gatti, L., Brienen, R., Feldpausch, T. R., Phillips, O. L., Miller, J., Ometto, J. P., Rocha, H., Baker, T., de Jong, B., Houghton, R. A., Malhi, Y., Aragão, L. E. O. C., Guyot, J.-L., Zhao, K., Jackson, R., Peylin, P., Sitch, S., Poulter, B., Lomas, M., Zaehle, S., Huntingford, C., Levy, P., and Lloyd, J.: The carbon balance of South America: a review of the status, decadal trends and main determinants, Biogeosciences, 9, 5407-5430, doi:10.5194/bg-9-5407-2012, 2012.

Goll, D. S., Brovkin, V., Parida, B. R., Reick, C. H., Kattge, J., Reich, P. B., van Bodegom, P. M., and Niinemets, Ü.: Nutrient lim- itation reduces land carbon uptake in simulations with a model of combined carbon, nitrogen and phosphorus cycling, Biogeosciences, 9, 3547-3569, doi:10.5194/bg-9-3547-2012, 2012.

Hess, L., Melack, J. M., Novo, E. M. L. M., Barbosa, C. C., and Gastil, M.: Dual-season mapping of wetland inundation and vegetation for the central Amazon basin, Remote Sens. Environ., 87, 404-428, doi:10.1016/j.rse.2003.04.001, 2003.

Hodson, E. L., Poulter, B., Zimmermann, N. E., Prigent, C., and Kaplan, J. O.: The El Niño - Southern Oscillation and wetland methane interannual variability, Geophy. Res. Lett., 38, L08810, doi:10.1029/2011GL046861, 2011.

Houweling, S., Krol, M., Bergamaschi, P., Frankenberg, C., Dlugokencky, E. J., Morino, I., Notholt, J., Sherlock, V., Wunch, D., Beck, V., Gerbig, C., Chen, H., Kort, E. A., Röckmann, T., and Aben, I.: A multi-year methane inversion using SCIAMACHY, accounting for systematic errors using TCCON measurements, Atmos. Chem. Phys. Discuss., 13, 28117-28171, doi:10.5194/acpd-13-28117-2013, 2013.

HYDRO1k Elevation Derivative Database, U.S. Geological Survey Earth Resources Observation and Science (EROS) Center, LP DAAC, http://gcmd.nasa.gov/records/GCMD_HYDRO1k.html, 2004.

Junk, W. and Furch, K.: A general review of tropical South American floodplains, Wetl. Ecol. Manag., 2, 231-238, available at: http://www.springerlink.com/index/G11101V510011652.pdf (last access: 31 October 2012), 1993.

Junk, W. J., Piedade, M. T. F., Schöngart, J., Cohn-Haft, M., Adeney, J. M., and Wittmann, F.: A Classification of Major Naturally-Occurring Amazonian Lowland Wetlands, Wetlands, 31, 623-640, doi:10.1007/s13157-011-0190-7, 2011.

Keller, M.: Biological sources and sinks of methane in tropical habitats and tropical atmospheric chemistry, Ph.D. diss., Coop. Thesis 126, Princeton Univ., Princeton, NJ, 1990.

Kirschke, S., Bousquet, P., Ciais, P., Saunois, M., Canadell, J. G., Dlugokencky, E. J., Bergamaschi, P., Bergmann, D., Blake, D. R., Bruhwiler, L., Cameron-Smith, P., Castaldi, S., Chevallier, F., Feng, L., Fraser, A., Heimann, M., Hodson, E. L., Houweling, S., Josse, B., Fraser, P. J., Krummel, P. B., Lamarque, J. F., Langenfelds, R. L., Le Quéré, C., Naik, V., O’Doherty, S., Palmer, P. I., Pison, I., Plummer, D., Poulter, B., Prinn, R. G., Rigby, M., Ringeval, B., Santini, M., Schmidt, M., Shindell, D. T., Simpso, I. J., Spahni, R., Steele, L. P., Strode, S. A., Sudo, K., Szopa, S., van der Werf, G. R., Voulgarakis, A., van Weele, M., Weiss, R. F., Williams, J. E., Zeng, G., and Guido, R.: Three decades of global methane sources and sinks, Nat. Geosci., 6, 813-823, doi:10.1038/ngeo1955, 2013

Krinner, G., Viovy, N., De Noblet-Ducoudré, N., Ogée, J., Polcher, J., Friedlingstein, P., Ciais, P., Sitch, S., and Prentice, I. C.: A dynamic global vegetation model for studies of the coupled atmosphere-biosphere system, Global Biogeochem. Cy., 19, GB1015, doi:10.1029/2003GB002199, 2005.

Lehner, B. and Döll, P.: Development and validation of a global database of lakes, reservoirs and wetlands, J. Hydrol., 296, 1-22, doi:10.1016/j.jhydrol.2004.03.028, 2004.

Lorenz, C. and Kunstmann, H.: The Hydrological Cycle in Three State-of-the-Art Reanalyses: Intercomparison and Performance Analysis, J. Hydrometeor., 13, 1397-1420, doi:10.1175/JHM-D11-088.1, 2012. 
Loulergue, L., Schilt, A., Spahni, R., Masson-Delmotte, V., Blunier, T., Lemieux, B., Barnola, J.-M., Raynaud, D., Stocker, T. F., and Chappellaz, J.: Orbital and millennial-scale features of atmospheric $\mathrm{CH}_{4}$ over the past 800,000 years, Nature, 453, 383 386, doi:10.1038/nature06950, 2008.

Marani, L. and Alvalá, P. C.: Methane emissions from lakes and floodplains in Pantanal, Brazil, Atmos. Environ., 41, 1627-1633, doi:10.1016/j.atmosenv.2006.10.046, 2007.

Melack, J., Hess, L., Gastil, M., Forsberg, B., Hamilton, S., Lima, I. B., and Novo, E. M. L. M.: Regionalization of methane emissions in the Amazon Basin with microwave remote sensing, Glob. Change Biol., 10, 530-544, doi:10.1111/j.15298817.2003.00763.x, 2004.

Melack, J. M. and Hess, L. L.: Remote Sensing of the Distribution and Extent of Wetlands in the Amazon Basin, in Amazonian Floodplain Forests: Ecophysiology, Biodiversity and Sustainable Management, vol. 210, edited by: Junk, W. J., Piedade, M. T. F., Wittmann, F., Schöngart, J., and Parolin, P., 43-59, Springer Netherlands, Dordrecht, 2010.

Melton, J. R., Wania, R., Hodson, E. L., Poulter, B., Ringeval, B., Spahni, R., Bohn, T., Avis, C. A., Beerling, D. J., Chen, G., Eliseev, A. V., Denisov, S. N., Hopcroft, P. O., Lettenmaier, D. P., Riley, W. J., Singarayer, J. S., Subin, Z. M., Tian, H., Zürcher, S., Brovkin, V., van Bodegom, P. M., Kleinen, T., Yu, Z. C., and Kaplan, J. O.: Present state of global wetland extent and wetland methane modelling: conclusions from a model intercomparison project (WETCHIMP), Biogeosciences, 10, 753788, doi:10.5194/bg-10-753-2013, 2013.

Miguez-Macho, G. and Fan, Y.: The role of groundwater in the Amazon water cycle: 1. Influence on seasonal streamflow, flooding and wetlands, J. Geophys. Res.-Atmos., 117, D15113, doi:10.1029/2012JD017539, 2012.

Miller, J. B., Gatti, L. V., d'Amelio, M. T. S., Crotwell, A. M., Dlugokencky, E. J., Bakwin, P., Artaxo, P., and Tans, P. P.: Airborne measurements indicate large methane emissions from the eastern Amazon basin, Geophys. Res. Lett., 34, L10809, doi:10.1029/2006GL029213, 2007.

Mistch, W. J. and Gosselink, J. G.: Wetlands, 3rd ed., edited by: Wiley, J. and N. J. Hoboken, 2000.

Mitchell, T. D. and Jones, P. D.: An improved method of constructing a database of monthly climate observations and associated high-resolution grids, Int. J. Climatol., 25, 693-712, available at: https://ueaeprints.uea.ac.uk/34092/, 2005.

New, M., Lister, D., Hulme, M., and Makin, I.: A high-resolution data set of surface climate over global land areas, Climate Res., $21,1-25,2002$.

Nisbet, R. E. R., Fisher, R., Nimmo, R. H., Bendall, D. S., Crill, P. M., Gallego-Sala, a V, Hornibrook, E. R. C., López-Juez, E., Lowry, D., Nisbet, P. B. R., Shuckburgh, E. F., Sriskantharajah, S., Howe, C. J., and Nisbet, E. G.: Emission of methane from plants, P Roy. Soc. B-Biol. Sci., 276, 1347-1354, doi:10.1098/rspb.2008.1731, 2009.

Papa, F., Prigent, C., Aires, F., Jimenez, C., Rossow, W. B., and Matthews, E.: Interannual variability of surface water extent at the global scale, 1993-2004, J. Geophys. Res., 115, 1-17, doi:10.1029/2009JD012674, 2010.

Petrescu, A. M. R., Van Beek, L. P. H., Van Huissteden, J., Prigent, C., Sachs, T., Corradi, C. A. R., Parmentier, F. J. W. and Dolman, A. J.: Modeling regional to global $\mathrm{CH}_{4}$ emissions of bo- real and arctic wetlands, Global Biogeochem. Cy., 24, GB4009, doi:10.1029/2009GB003610, 2010.

Piedade, M., Junk, W., and Long, S.: The Productivity of the C_4 Grass Echinochloa Polystachya on the Amazon Floodplain, Ecology, 72, 1456-1463, available at: http://www.jstor. org/stable/10.2307/1941118 (last access: 31 October 2012), 1991.

Piedade, M. T. F., Junk, W., D‘Ângelo, S. A., Wittmann, F., Schöngart, J., Barbosa, K. M. D. N., and Lopes, A.: Aquatic herbaceous plants of the Amazon floodplains: state of the art and research needed, Acta Limnol. Brasil., 22, 165-178, doi:10.4322/actalb.02202006, 2010.

Pison, I., Ringeval, B., Bousquet, P., Prigent, C., and Papa, F.: Stable atmospheric methane in the 2000s: key-role of emissions from natural wetlands, Atmos. Chem. Phys. Discuss., 13, 9017-9049, doi:10.5194/acpd-13-9017-2013, 2013.

Prigent, C., Papa, F., Aires, F., Rossow, W. B., and Matthews, E.: Global inundation dynamics inferred from multiple satellite observations, 1993-2000, J. Geophys. Res., 112, D12107, doi:10.1029/2006JD007847, 2007.

Querino, C. A. S., Smeets, C. J. P. P., Vigano, I., Holzinger, R., Moura, V., Gatti, L. V., Martinewski, A., Manzi, A. O., de Araujo, A. C., and Röckmann, T. R.: Methane flux, vertical gradient and mixing ratio measurements in a tropical forest, Atmos. Chem. Phys., 11, 7943-7953, doi:10.5194/acp-11-7943201, 2011

Reichardt, T.: Academy under fire on "wetlands" definition, Nature, 375, 6528, doi:10.1038/375171a0, 1995.

Riley, W. J., Subin, Z. M., Lawrence, D. M., Swenson, S. C., Torn, M. S., Meng, L., Mahowald, N. M., and Hess, P.: Barriers to predicting changes in global terrestrial methane fluxes: analyses using CLM4Me, a methane biogeochemistry model integrated in CESM, Biogeosciences, 8, 1925-1953, doi:10.5194/bg-8-19252011, 2011.

Ringeval, B., Decharme, B., Piao, S. L., Ciais, P., Papa, F., de Noblet-Ducoudré, N., Prigent, C., Friedlingstein, P., Gouttevin, I., Koven, C., and Ducharne, A.: Modelling sub-grid wetland in the ORCHIDEE global land surface model: evaluation against river discharges and remotely sensed data, Geosci. Model Dev., 5, 941-962, doi:10.5194/gmd-5-941-2012, 2012.

Ringeval, B., Friedlingstein, P., Koven, C., Ciais, P., De NobletDucoudré, N., Decharme, B., and Cadule, P.: Climate- $\mathrm{CH}_{4}$ feedback from wetlands and its interaction with the climate$\mathrm{CO}_{2}$ feedback, Biogeosciences, 8, 2137-2157, doi:10.5194/bg8-2137-2011, 2011.

Ringeval, B., Hopcroft, P. O., Valdes, P. J., Ciais, P., Ramstein, G., Dolman, A. J., and Kageyama, M.: Response of methane emissions from wetlands to the Last Glacial Maximum and an idealized Dansgaard-Oeschger climate event: insights from two models of different complexity, Clim. Past, 9, 149-171, doi:10.5194/cp-9-149-2013, 2013.

Ringeval, B., De Noblet-Ducoudré, N., Ciais, P., Bousquet, P., Prigent, C., Papa, F., and Rossow, W. B.: An attempt to quantify the impact of changes in wetland extent on methane emissions on the seasonal and interannual time scales, Global Biogeochem. Cy., 24, GB2003, doi:10.1029/2008GB003354, 2010.

Schöngart, J., Wittmann, F., and Worbes, M.: Biomass and Net Primary Production of Central Amazonian Floodplain Forests, in: Amazonian Floodplain Forests: Ecophysiology, Biodiver- 
sity and Sustainable Management, edited by: Junk, W. J., Piedade, M. T. F., Wittmann, F., Schöngart, J., and Parolin, P., 18, 347-388, Ecological Studies 210, doi:10.1007/978-90-4818725-6_18, Springer Science+Business Media B.V., 2010

Singarayer, J. S., Valdes, P. J., Friedlingstein, P., Nelson, S., and Beerling, D. J.: Late Holocene methane rise caused by orbitally controlled increase in tropical sources, Nature, 470, 8285, doi:10.1038/nature09739, 2011.

Sitch, S., Smith, B., Prentice, I., Arneth, A., Bondeau, A., Cramer, W., Kaplan, J., Levis, S., Lucht, W., Sykes, M., Thonicke, K., and Venevsky, S.: Evaluation of ecosystem dynamics, plant geography and terrestrial carbon cycling in the LPJ dynamic global vegetation model, Glob. Change Biol., 9, 161-185, 2003.

Smith, L. K., Lewis, W. M., Chanton, J. P., Cronin, G., and Hamilton, S. K.: Methane emissions from the Orinoco River floodplain, Venezuela, Biogeochemistry, 51, 113-140, 2000.

Spahni, R., Joos, F., Stocker, B. D., Steinacher, M., and Yu, Z. C.: Transient simulations of the carbon and nitrogen dynamics in northern peatlands: from the Last Glacial Maximum to the 21st century, Clim. Past, 9, 1287-1308, doi:10.5194/cp-9-1287-2013, 2013.

Spahni, R., Wania, R., Neef, L., van Weele, M., Pison, I., Bousquet, P., Frankenberg, C., Foster, P. N., Joos, F., Prentice, I. C., and van Velthoven, P.: Constraining global methane emissions and uptake by ecosystems, Biogeosciences, 8, 1643-1665, doi:10.5194/bg8-1643-2011, 2011.

Stocker, B. D., Roth, R., Joos, F., Spahni, R., Steinacher, M., Zaehle, S., Bouwman, L., Xu-Ri and Prentice, I. C.: Multiple greenhouse-gas feedbacks from the land biosphere under future climate change scenarios, Nat. Clim. Change, 3, 666-672, doi:10.1038/nclimate1864, 2013

Strassmann, K. M., Joos, F., and Fischer, G.: Simulating effects of land use changes on carbon fluxes: past contributions to atmospheric $\mathrm{CO}_{2}$ increases and future commitments due to losses of terrestrial sink capacity, Tellus B, 60, 583-603, doi:10.1111/j.1600-0889.2008.00340.x, 2008.

Tarnocai, C., Canadell, J. G., Schuur, E. a. G., Kuhry, P., Mazhitova, G., and Zimov, S.: Soil organic carbon pools in the northern circumpolar permafrost region, Global Biogeochem. Cy., 23, GB2023, doi:10.1029/2008GB003327, 2009.

The Land Cover Map for South America in the Year 2000, edited by: Eva, H. D., E. E. de Miranda, Di Bella, C. M., Gond, V., Huber, O., Sgrenzaroli, M., Jones, S., Coutinho, A., Dorado, A.,Guimares, M., Elvidge, C., Achard, F., Belward, A. S., Bartholom, E., Baraldi, A., De Grandi, G., Vogt, P., Fritz, S., Hartley, A., GLC2000 database, European Commision Joint Research Centre, http://bioval.jrc.ec.europa.eu/products/ glc2000/products.php, 2003.

Tian, H., Xu, X., Liu, M., Ren, W., Zhang, C., Chen, G., and Lu, C.: Spatial and temporal patterns of $\mathrm{CH}_{4}$ and $\mathrm{N}_{2} \mathrm{O}$ fluxes in terrestrial ecosystems of North America during 1979-2008: application of a global biogeochemistry model, Biogeosciences, 7, 2673-2694, doi:10.5194/bg-7-2673-2010, 2010.

Tian, H. Q., Xu, X. F., Lu, C. Q., Liu, M. L., Ren, W., Chen, G. S., Melillo, J., and Liu, J. Y.: Net exchanges of $\mathrm{CO}_{2}, \mathrm{CH}_{4}$, and $\mathrm{N}_{2} \mathrm{O}$ between China's terrestrial ecosystems and the atmosphere and their contributions to global climate warming, J. Geophys. Res., 116, G02011, doi:10.1029/2010JG001393, 2011.
Van Beek, L. P. H., Wada, Y., and Bierkens, M. F. P.: Global monthly water stress: 1. Water balance and water availability, Water Resour. Res., 47, W07517, doi:10.1029/2010WR009791, 2011.

Van Beek, R. and Bierkens, M.: The Global Hydrological Model PCR-GLOBWB: Conceptualization, Parameterization and Verification, in Department of Physical Geography Faculty of Earth Sciences - Utrecht University, 1-53, available at: http://vanbeek. geo.uu.nl/suppinfo/vanbeekbierkens2009.pdf, 2009.

Vigano, I., van Weelden, H., Holzinger, R., Keppler, F., McLeod, A., and Röckmann, T.: Effect of UV radiation and temperature on the emission of methane from plant biomass and structural components, Biogeosciences, 5, 937-947, doi:10.5194/bg-5-937-2008, 2008.

Walker, J. H.: The Llanos de Mojos, in The Handbook of South American Archaeology, 927-939, Springer New York, 2008.

Walter, B. P. and Heimann, M.: A process-based, climate-sensitive model to derive methane emissions from natural wetlands: Application to five wetland sites, sensitivity to model parameters, and climate, Global Biogeochem. Cy., 14, 745-765, doi:10.1029/1999GB001204, 2000

Wania, R.: Modelling northern peatland land surface processes, vegetation dynamics and methane emissions, Ph.D. thesis, University of Bristol, 2007.

Wania, R., Melton, J. R., Hodson, E. L., Poulter, B., Ringeval, B., Spahni, R., Bohn, T., Avis, C. A., Chen, G., Eliseev, A. V., Hopcroft, P. O., Riley, W. J., Subin, Z. M., Tian, H., van Bodegom, P. M., Kleinen, T., Yu, Z. C., Singarayer, J. S., Zürcher, S., Lettenmaier, D. P., Beerling, D. J., Denisov, S. N., Prigent, C., Papa, F., and Kaplan, J. O.: Present state of global wetland extent and wetland methane modelling: methodology of a model inter-comparison project (WETCHIMP), Geosci. Model Dev., 6, 617-641, doi:10.5194/gmd-6-617-2013, 2013.

Wania, R., Ross, I., and Prentice, I.: Integrating peatlands and permafrost into a dynamic global vegetation model: 2 . Evaluation and sensitivity of vegetation and carbon cycle processes, Global Biogeochem. Cy., 23, GB3015, doi:10.1029/2008GB003413, 2009a.

Wania, R., Ross, I., and Prentice, I. C.: Integrating peatlands and permafrost into a dynamic global vegetation model: 1 . Evaluation and sensitivity of physical land surface processes, Global Biogeochem. Cy., 23, GB3014, doi:10.1029/2008GB003412, 2009b.

Wania, R., Ross, I., and Prentice, I. C.: Implementation and evaluation of a new methane model within a dynamic global vegetation model: LPJ-WHyMe v1.3.1, Geosci. Model Dev., 3, 565-584, doi:10.5194/gmd-3-565-2010, 2010.

Wassmann, R., Thein, U. G., Whiticar, M. J., Rennenberg, H., Seiler, W., and Junk, W. J.: Methane emissions from the Amazon floodplain: characterization of production and transport, Global Biogeochem. Cy., 6, 3-13, doi:10.1029/91GB01767, 1992.

Winsemius, H. C., Van Beek, L. P. H., Jongman, B., Ward, P. J., and Bouwman, A.: A framework for global river flood risk assessments, Hydrol. Earth Syst. Sci., 17, 1871-1892, doi:10.5194/hess-17-1871-2013, 2013.

Wittmann, F., Anhuf, D., and Funk, W. J.: Tree species distribution and community structure of central Amazonian várzea forests by remote-sensing techniques, J. Tropical Ecol., 18, 805-820, doi:10.1017/S0266467402002523, 2002. 
Wittmann, F., Schongart, J., Montero, J. C., Motzer, T., Junk, W. J., Piedade, M. T. F., Queiroz, H. L., and Worbes, M.: Tree species composition and diversity gradients in white-water forests across the Amazon Basin, J. Biogeogr., 33, 1334-1347, doi:10.1111/j.1365-2699.2006.01495.x, 2006.

Xu, X. F., Tian, H. Q., Zhang, C., Liu, M. L., Ren, W., Chen, G. S., Lu, C. Q., and Bruhwiler, L.: Attribution of spatial and temporal variations in terrestrial methane flux over North America, Biogeosciences, 7, 3637-3655, doi:10.5194/bg-7-3637-2010, 2010.

Yu, Z., Loisel, J., Brosseau, D. P., Beilman, D. W., and Hunt, S. J.: Global peatland dynamics since the Last Glacial Maximum, Geophys. Res. Lett., 37, L13402, doi:10.1029/2010GL043584, 2010.

Zhao, M., Heinsch, F. A., Nemani, R. R., and Running, S. W.: Improvements of the MODIS terrestrial gross and net primary production global data set, Remote Sens. Environ., 95, 164-176, doi:10.1016/j.rse.2004.12.011, 2005.
Zhao, M. and Running, S. W.: Drought-induced reduction in global terrestrial net primary production from 2000 through 2009, Science (New York, N.Y.), 329, 940-943, doi:10.1126/science.1192666, 2010.

Zhuang, Q., Melilo, J., Kicklighter, W., Prinn, R., McGuire, A., Steudler, P., Felze, B., and Hu, S.: Methane fluxes between terrestrial ecosystems and the atmosphere at northern high latitudes during the past century: A retrospective analysis with a process-based biogeochemistry model, Global Biogeochem. Cy., 18, GB3010, doi:10.1029/2004GB002239, 2004.

Zürcher, S., Spahni, R., Joos, F., Steinacher, M., and Fischer, H.: Impact of an abrupt cooling event on interglacial methane emissions in northern peatlands, Biogeosciences, 10, 1963-1981, doi:10.5194/bg-10-1963-2013, 2013. 


\section{Appendix A}

The four criteria applied to select grid cells in computation of the mean $\mathrm{LPX} \mathrm{CH}_{4}$ flux density over large geographical areas (Fig. 7) are as follows:

(i) A grid cell is selected as a "flooded grass" (or "flooded forest") ecosystem if the FPC of the corresponding vegetation is larger than $25 \%$ of the floodplain LU area.

(ii) A grid cell is selected as "flooded grass" (respectively "flooded forest") ecosystem if the flooded grass NPP is larger than the flooded forest NPP (respectively lower). This allows us to account for some seasonality in the phenology (while the FPC is constant at yearly timescale).

(iii) Same as (i) but keep only grid cells where flooding depth $>0.1 \mathrm{~m}$.

(vi) Same as (i) but introduce a floodplain extent area weighting (allow to account for increased probability of sample for large floodplain extent if we assume the measurements are randomly made).
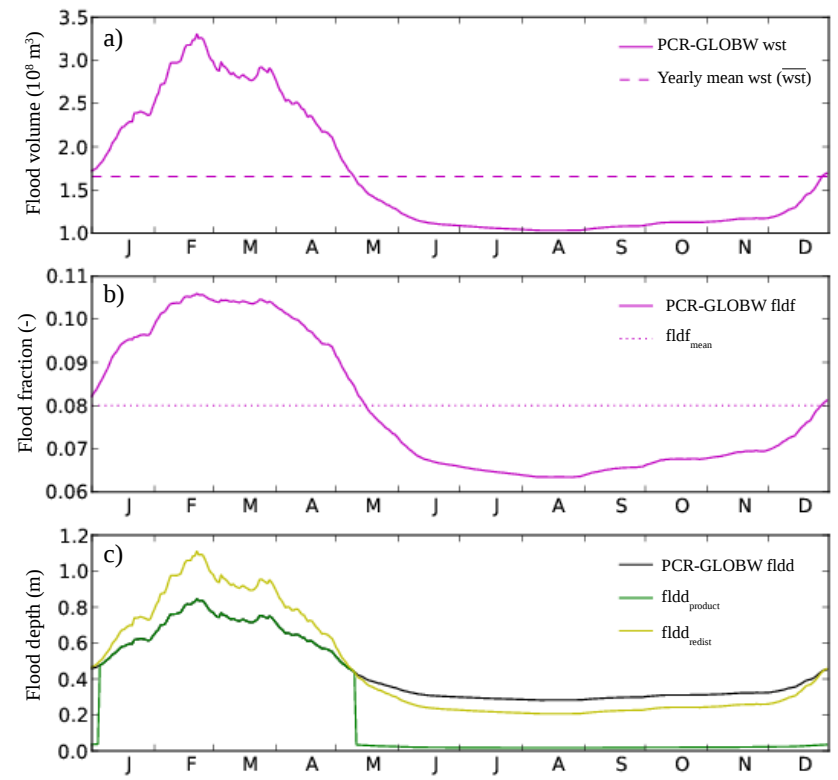

Fig. A1. On a given grid cell, outputs of PCR-GLOBWB and corresponding inputs to LPX: (a) Water storage: seasonal cycle simulated by PCR-GLOBWB (solid) and mean annual value (dashed); (b) floodplain fraction: seasonal cycle simulated by PCR-GLOBWB (solid) and yearly constant value derived from mean annual water storage (dotted; called fldf mean); (c) flood depth: output of PCRGLOBWB (black, fldd) over a seasonal-variable floodplain fraction and flood depths (fldd product $_{\text {and }}$ fldd $\left._{\text {redist }}\right)$ computed over the yearly constant floodplain fraction ( fldf $\left._{\text {mean }}\right)$. Both fldd $_{\text {redistt }}$ and fldd $_{\text {poduct }}$ are used as input of LPX. See Eq. (1) and 2 for computation of fldd redist $_{\text {and fldd }}$ product .

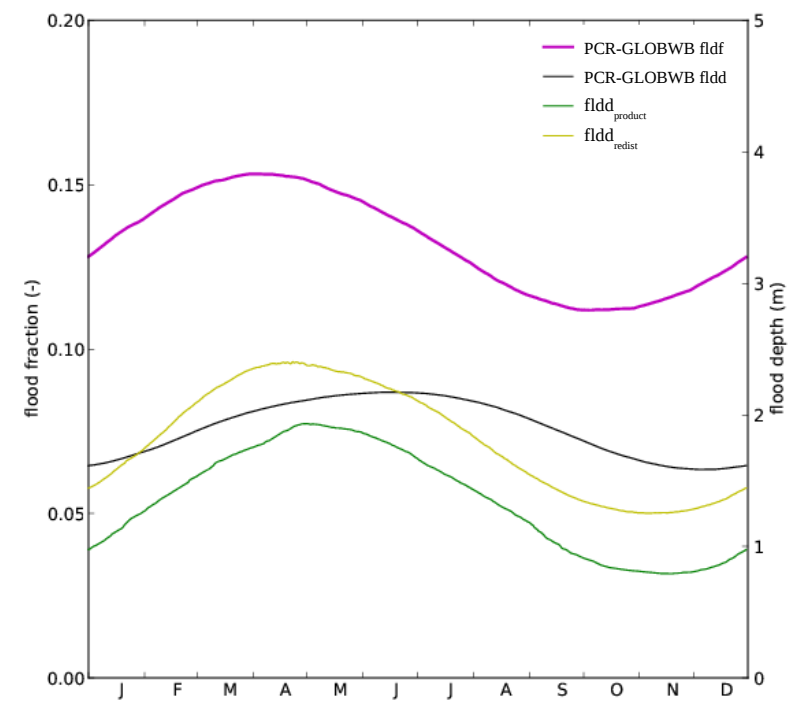

Fig. A2. Seasonal cycle of PCR-GLOBWB outputs and corresponding LPX inputs over the whole Amazon Basin. Floodplain fraction (magenta) and flood depth (black, green, yellow) are given. Note that fldd $\mathrm{froduct}_{\text {and }}$ fldd $\mathrm{d}_{\text {redist }}$ corresponds to flood depth over a yearly constant floodplain fraction ( fldf $_{\text {mean }}$ ) while PCR-GLOBWB fldd is given for a seasonal-variable floodplain fraction. 
a) MODIS NPP

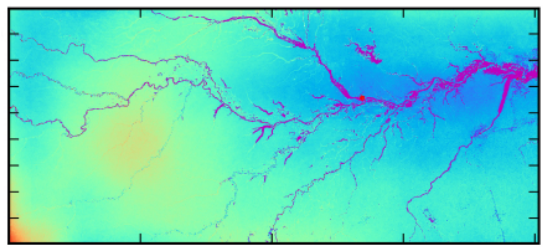

c) MODIS NPP for GLC2000 floodplain ecosystems

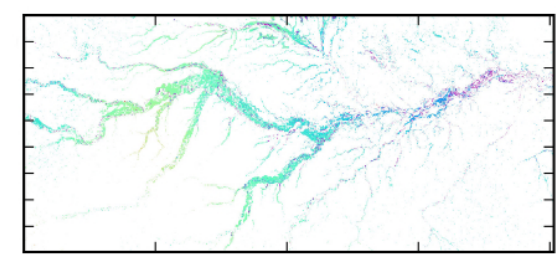

b) MODIS NPP for GLC2000 non-floodplain ecosystems

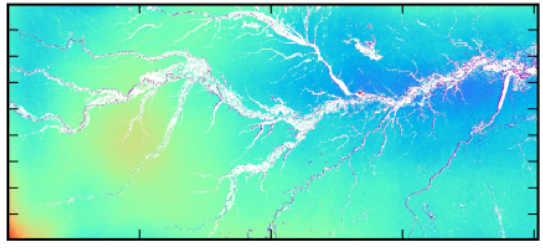

d) MODIS NPP for GLC2000 water-bodies

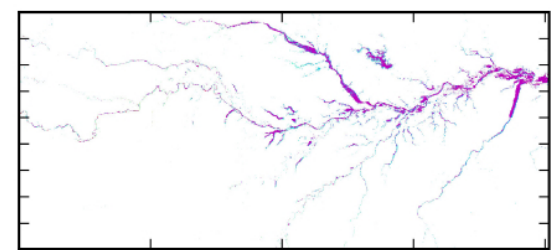

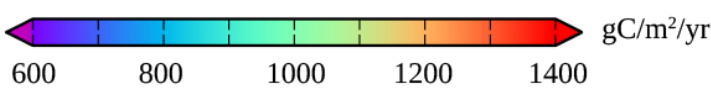

Fig. A3. MODIS-derived NPP for different ecosystems at GLC2000 resolution over the quadrate defined by Hess et al. (2004). Total MODIS NPP is displayed (a), as well as MODIS NPP for non-floodplain (b), floodplain (c) and water bodies (d) as defined in GLC2000.
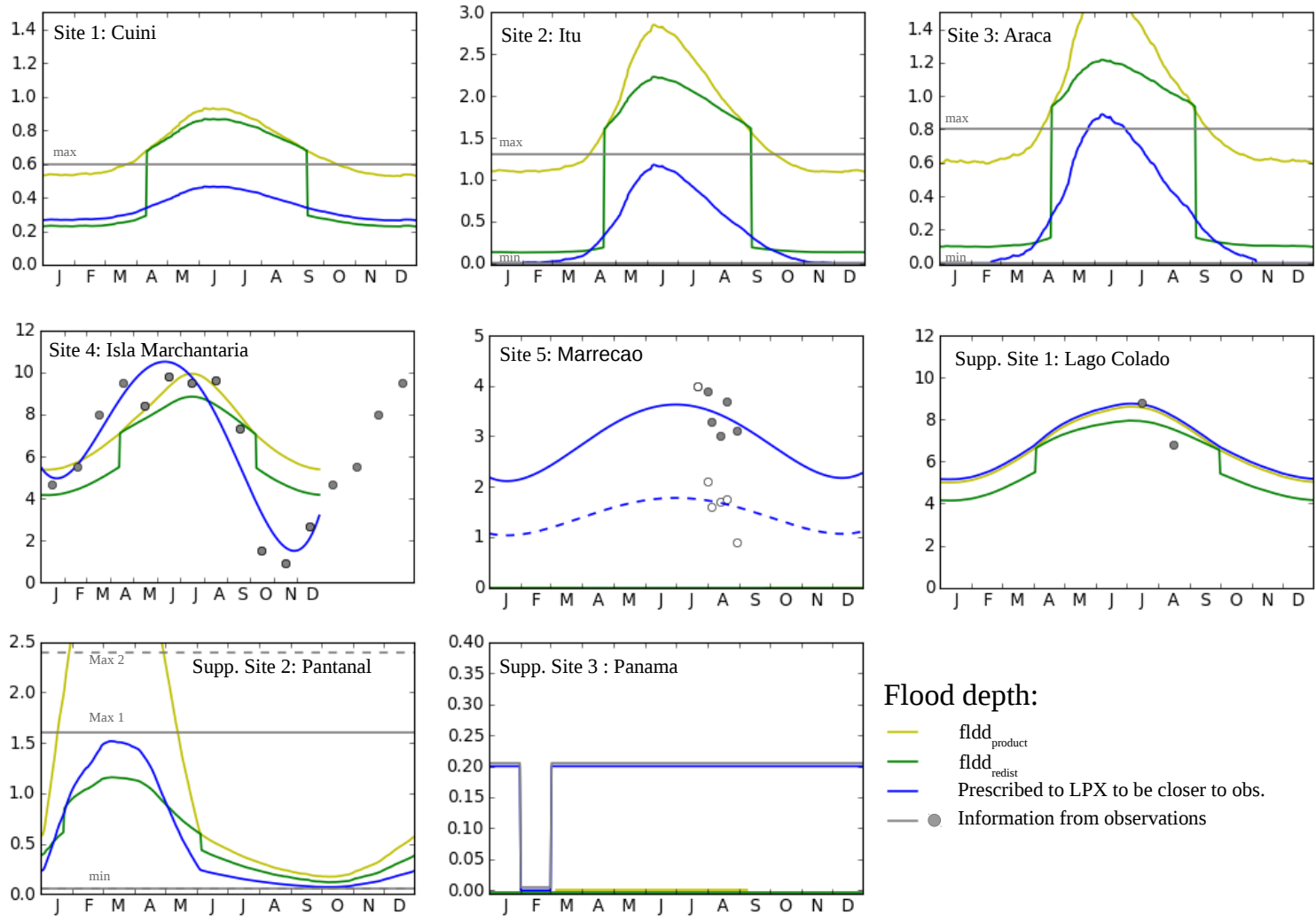

Flood depth:

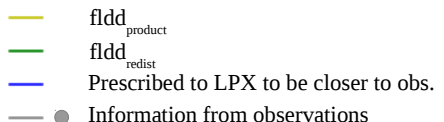

Fig. A4. Seasonal cycle of flood depth prescribed to LPX for simulations on sites. Both flood depth computed using PCR-GLOBWB (fldd $\mathrm{d}_{\text {redist }}$ in green and fldd product in yellow) and flood depth prescribed to account for information on sites (blue) are plotted. Field information used to draw blue curves are given in grey and are from reference papers of each site (see Table 2). On sites 1, 2, 3 and Supp. Site 2, information given in reference papers corresponds to yearly maximum/minimum values. On site 5, observed flood depths for plots with both flooded forests (white-filled circles) and floating macrophytes (grey-filled circles) are explicitly given. 


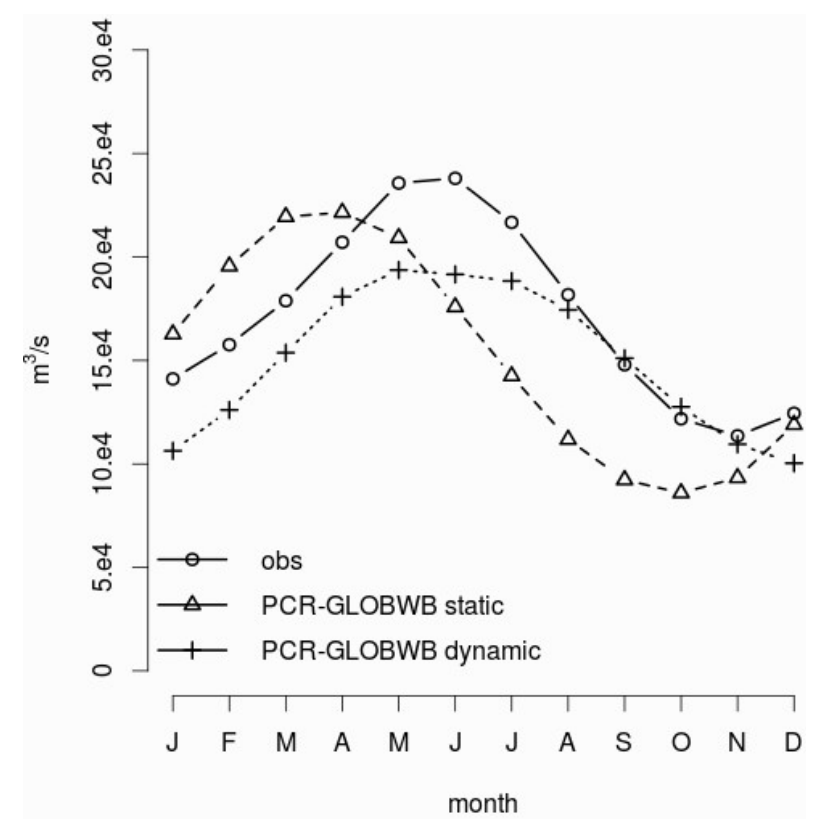

Fig. A5. Hydrograph at Obidos: comparison between observations (circles) and PCR-GLOBWB simulations (triangles and crosses). This figure shows the improvement in simulated seasonality when dynamic in floodplain extent is accounted for in PCR-GLOBWB (crosses, this study) against static floodplain area (triangles, Van Beek et al., 2011).

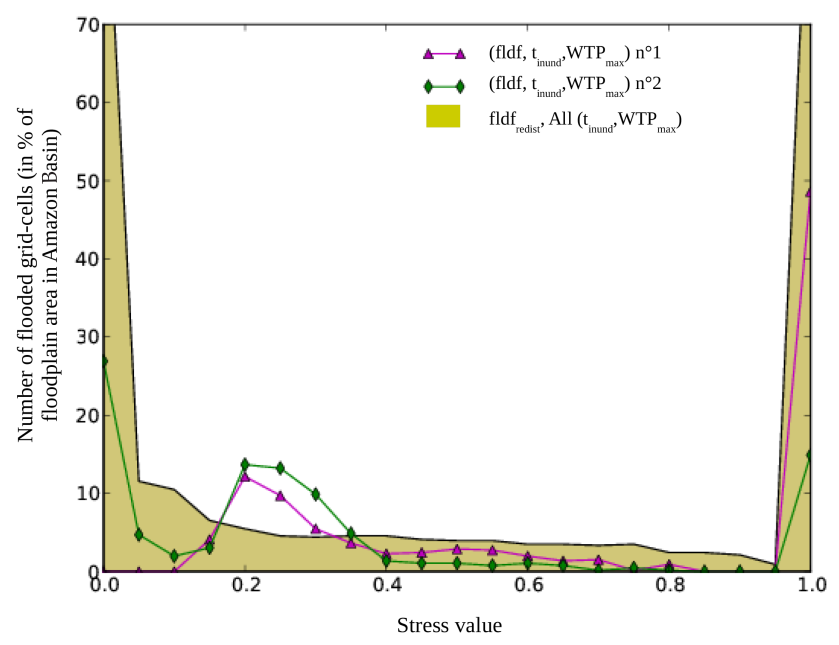

Fig. A6. Distribution of inundation stress on NPP for forests over the Amazon Basin. The percents of floodplain in the Amazon Basin with a given stress value are shown on the $y$ axis. The stress distribution is related to the way to account for fldd ( fldd $_{\text {redist }}$ or fldd product $)$ and the value of the $\left(\mathrm{WTP}_{\max }, t_{\text {inund }}\right)$ parameters. In parameter combinations 1 (magenta) and 2 (green), fldd product $_{\text {is }}$ used (see Table 1). Yellow area corresponds to the possible range of stress distribution with fldd redist $_{\text {and the }}\left(\mathrm{WTP}_{\max }, t_{\text {inund }}\right)$ values.

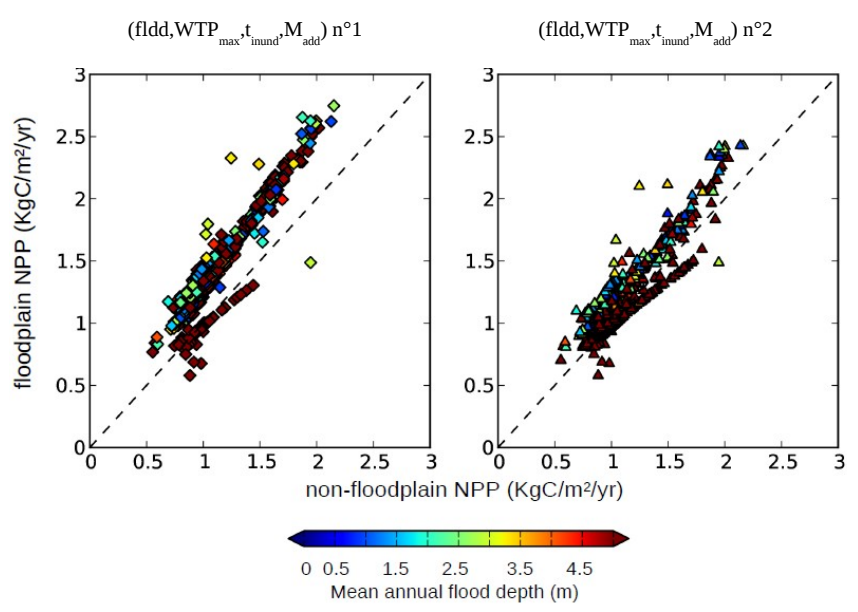

Fig. A7. Same as Fig. 4d except that LPX simulations 1 and 2 (cf. Table 1) are separately plotted. Information about the mean annual flood depth is added (color pallet). The mean annual flood depth is used here as proxy of the NPP inundation-related stress for forests. 
Site 4 : Isla Marchantaria (open water)

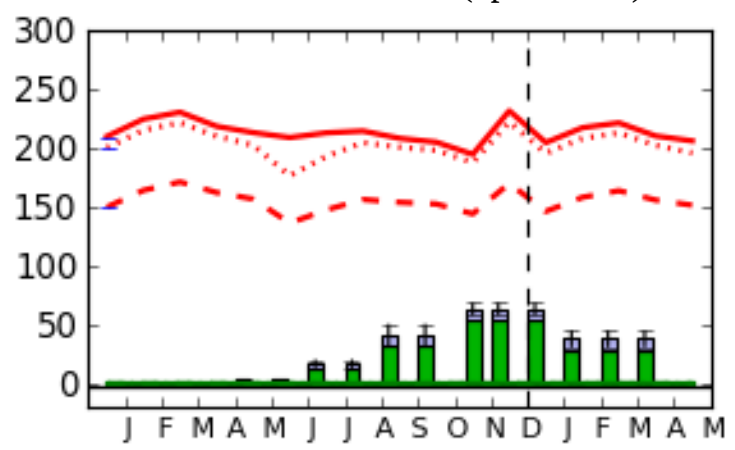

Supp. Site 1 : Lago Colado (open-water)

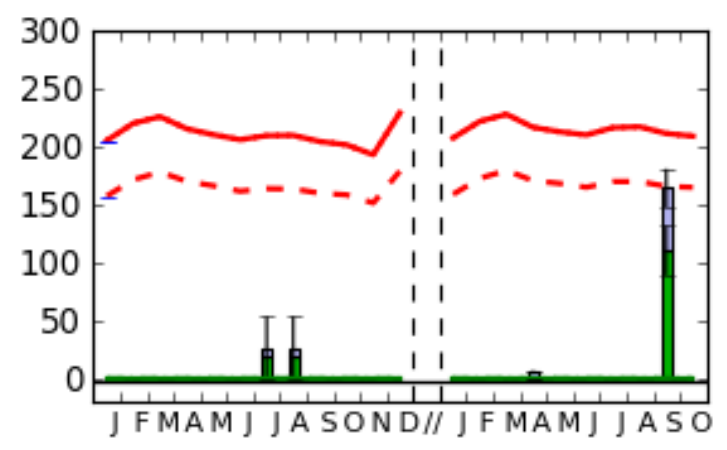

Site 5 : Marrecao/etc. (open water)

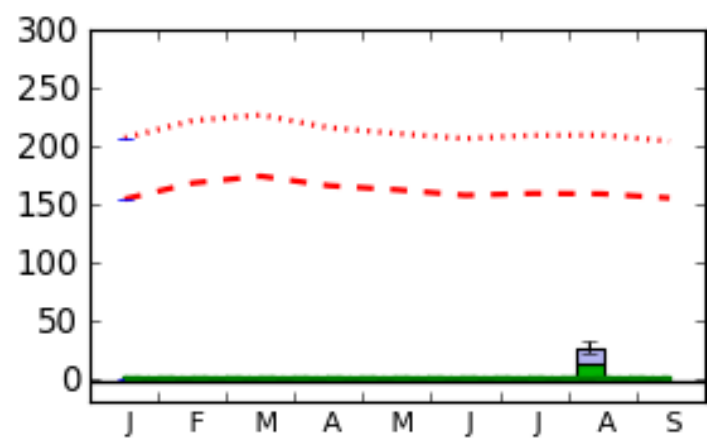

Observation: bars

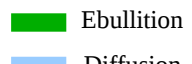

LPX: lines

- Ebullition

+ Plant

+ Diffusion

- Simul 1

....... Simul 2 (WTD)

- . - - Simul 3 (WTD + MODIS)

Fig. A8. Comparison between LPX-simulated $\mathrm{CH}_{4}$ flux densities and open-water measurements for sites 4 and 5 and Supp. Site 1. Plotted LPX simulations correspond to simulations 1-3 (cf. Table 4). 
Table A1. Description of the main parameters/variables introduced in LPX to represent Amazon floodplains.

\begin{tabular}{|c|c|c|}
\hline Acronyms & Description & Information about its computation or value \\
\hline LU & Land unit & Natural (i.e., non floodplain) or floodplain \\
\hline fldf $_{\text {mean }}$ & Yearly constant floodplain extent & cf. Fig. 1b for 1979-2009 climatology \\
\hline fldd $_{L P X}$ & Flood depth over fldf mean; equal to either fldd redist $_{\text {or fldd }}$ product & cf. Eq. (1) and (2) \\
\hline $\mathrm{WTP}_{\max }$ & $\begin{array}{l}\text { Threshold water table (WTPmax), above which a PFT } \\
\text { experiences inundation }\end{array}$ & cf. Table 1 \\
\hline$t_{\text {inund }}$ & $\begin{array}{l}\text { Maximal survival duration of inundation, which counts how many } \\
\text { days a plant functional type can survive under inundation }\end{array}$ & cf. Table 1 \\
\hline$M_{\text {add }}$ & Constant additional mortality for flood-tolerant trees at flooding & cf. Table 1 \\
\hline$R_{\text {moist }}$ & $\begin{array}{l}\text { Sensitivity of carbon decomposition to soil water content, set to } \\
\text { a constant value }\end{array}$ & 0.5 \\
\hline$a_{\mathrm{NPP}}$ & $\begin{array}{l}\text { Ratio measuring the influence of phosphorus and other } \\
\text { shortcomings in the LPX. This ratio is computed over } \\
\text { non-floodplain LU and will be applied on floodplain one. }\end{array}$ & cf. Eq. (4) \\
\hline$r_{\mathrm{CH}_{4} / \mathrm{CO}_{2}}$ & $\mathrm{CH}_{4} / \mathrm{CO}_{2}$ production ratio under fully total anaerobic conditions & 0.10 \\
\hline
\end{tabular}

Table A2. Statistics of linear regressions (non-floodplain NPP vs. floodplain NPP) when the intercept is forced to 0. Values are given for LPX (three simulations varying through the parameters combinations, see Table 1) and for MODIS (for both trees and grasses).

\begin{tabular}{lllll}
\hline & $\begin{array}{l}\text { Paired } \\
t \text { test }\end{array}$ & Slope & $\begin{array}{l}\text { Std error } \\
\text { slope }\end{array}$ & $\begin{array}{l}\text { 95\% Confidence } \\
\text { interval }\end{array}$ \\
\hline LPX - trees; 1 & $2.2 \times 10^{-16}$ & 0.898 & 0.00345 & $-0.109 ;-0.095$ \\
LPX - trees; 2 & $2.2 \times 10^{-16}$ & 0.936 & 0.00471 & $-0.073 ;-0.055$ \\
LPX - trees; 3 & $2.2 \times 10^{-16}$ & 0.949 & 0.00355 & $-0.058 ;-0.044$ \\
LPX - grasses; 1 & 0.0055 & 0.853 & 0.05365 & $-0.264 ;-0.030$ \\
LPX - grasses; 2 & 0.0483 & 0.672 & 0.1326 & $-0.6523 ;-0.003$ \\
LPX - grasses; 3 & 0.0692 & 0.815 & 0.08928 & $-0.386 ; 0.018$ \\
MODIS - trees & 0.121 & 1.004 & 0.00274 & $-0.001 ; 0.0097$ \\
MODIS - grasses & $2.97 \times 10^{-9}$ & 1.111 & 0.01589 & $0.079 ; 0.1435$ \\
\hline
\end{tabular}

